UNIVERSIDADE DE BRASÍLIA

FACULDADE DE TECNOLOGIA

DEPARTAMENTO DE ENGENHARIA FLORESTAL

\title{
ASPECTOS ECONÔMICOS DO EXTRATIVISMO \\ DO BARU NO VALE DO URUCUIA, MINAS GERAIS
}

\section{GABRIEL MÜLLER VALADÃO}

ORIENTADOR: ÁLVARO NOGUEIRA DE SOUSA

DISSERTAÇÃO DE MESTRADO EM CIÊNCIAS FLORESTAIS

PUBLICAÇÃO: PPGEFL. DM - 256/2016

BRASÍLIA/DF: FEVEREIRO - 2016 
UNIVERSIDADE DE BRASÍLIA

FACULDADE DE TECNOLOGIA

PROGRAMA DE PÓS-GRADUAÇÃO EM CIÊNCIAS FLORESTAIS

\section{ASPECTOS ECONÔMICOS DO EXTRATIVISMO DO BARU NO VALE DO URUCUIA, MINAS GERAIS}

GABRIEL MÜLLER VALADÃO

DISSERTAÇÃO DE MESTRADO SUBMETIDA AO PROGRAMA DE PÓS-GRADUAÇÃO EM CIÊNCIAS FLORESTAIS DA UNIVERSIDADE DE BRASÍLIA COMO REQUISITO PARCIAL À OBTENÇÃO DO TÍTULO DE MESTRE EM CIÊNCIAS FLORESTAIS.

APROVADA POR:

Dr. Álvaro Nogueira de Sousa

(Departamento de Engenharia Florestal - UnB)

(Orientador)

Dra . Janaína Deane de Abreu Diniz - UnB

Faculdade UnB Planaltina

(Examinadora externa)

Dra . Maísa Santos Joaquim

Faculdade de Agronomia e Medicina Veterinária - UnB

(Examinadora externa)

Dra . Rosana de Carvalho Cristo Martins

(Departamento de Engenharia Florestal - UnB)

(Examinadora suplente)

BRASÍLIA/DF, 25 DE FEVEREIRO - 2016 
Ficha catalográfica elaborada pela Biblioteca Central da Universidade de Brasília

REFERÊNCIA BIBLIOGRÁFICA

VALADÃO, G. M. (2016). ASPECTOS ECONÔMICOS DO EXTRATIVISMO DO BARU (Dipteryx alata Vog.) NO VALE DO RIO URUCUIA, MINAS GERAIS. Dissertação de Mestrado em Ciências Florestais. Publicação PPG/EFL. DM-256/2016, Programa de Pós-Graduação em Ciências Florestais, Universidade de Brasília, Brasília-DF, 100p.

CESSÃO DE DIREITOS

AUTOR: Gabriel Müller Valadão

TÍTULO: ASPECTOS ECONÔMICOS DO EXTRATIVISMO DO BARU NO VALE DO RIO URUCUIA, MINAS GERAIS.

GRAU: Mestre; ANO: 2016; ÁREA DE CONCENTRAÇÃO: Manejo Florestal

Concedo à Universidade de Brasília-UnB permissão para reproduzir cópias desta dissertação de mestrado e para emprestá-las somente para propósitos acadêmicos e científicos. Reservo outros direitos de publicação, de forma que nenhuma parte desta dissertação de mestrado pode ser reproduzida sem minha autorização por escrito.

Gabriel Müller Valadão

Endereço eletrônico: gmvaladao@hotmail.com 
Todos têm direito ao meio ambiente ecologicamente equilibrado, bem de uso comum do povo e essencial à sadia qualidade de vida, impondo-se ao Poder Público e à coletividade o dever de defendê-lo e preservá-lo para as presentes e futuras gerações (Artigo 225 da Constituição Federal). 


\section{AGRADECIMENTOS}

Agradeço a todos que contribuíram para o êxito desse trabalho, em especial a minha família, como a minha maravilhosa e guerreira esposa Bebel, mesmo com o nascimento de nossa linda e querida filha Carolina, mesmo mudando de emprego, conseguiu aturar minhas ansiedades e sobrecargas de trabalho, ao meu lindo e querido filho Cássio.

Agradeço ao meu Pai Lucas e minha Mãe Adelaide pelos ensinamentos, e pelo estímulo aos estudos, ao meu sogro Ojasto e minha sogra Biza, que tantas vezes se abdicaram de seus problemas pessoais, de saúde, entre outros, para estar aqui conosco e ajudar com nossas crianças, permitindo alguma imersão.

Agradecer ao meu orientador pelo estímulo, aprendizados e convivência, aos meus professores que muito contribuíram na minha formação, Prof. Anderson, Prof. Fernando Scárdua, Prof. Humberto, Profa. Rosana, Prof. Reginaldo.

Agradecer ao Instituto Federal do Norte de Minas Gerais pela oportunidade de retornar aos estudos, pela oportunidade de afastamento para estudos e bolsas do Programa de Bolsas para Qualificação de Servidores - PBQS. Agradecer ao CNPq pelo apoio concedido no projeto aprovado no edital de Apoio a Projetos Cooperativos de Pesquisa Aplicada e de Extensão Tecnológica.

Á equipe da COPABASE, em especial ao Nardélio, Dionete, Adriana e Marcos. Ao Luiz Carraza da Central do Cerrado e Cezar Victor da Funatura. Não me esquecendo dos técnicos da Conab, com as valiosas informações prestadas e Sueli Sano da Embrapa Cerrado pela troca de experiência.

Ao Professor e amigo Francisco, pela ajuda nas análises estatísticas e aos funcionários do Instituto Estadual de Florestas, a Gerente Tatiana e os funcionários extrativistas Valter e Zezinho.

Aos meus colegas de Pós, Danilo, Genilda, Ilvan, Maísa, Juliana e Natália, aos colegas de pós do IFNMG, Charles, Toninho, Elton, Roberto e Alison.

Aos bolsistas do Projeto "Cadeia produtiva o baru". Em especial Hugo, Mateus, Milena, Eridiane, Luciene, Eliene, Gustavo, Luiz Arthur, Tiago.

Aos agroextrativistas participantes das entrevistas, aos feirantes e demais colaboradores que contribuíram diretamente com a pesquisa, em especial o $\mathrm{Sr}$ Argerimo, Casu de Sagarana, Paulo Cabelereiro e Jair/Chico Mendes. 


\title{
RESUMO
}

\section{ASPECTOS ECONÔMICOS DO EXTRATIVISMO DO BARU NO VALE DO URUCUIA, MINAS GERAIS.}

\author{
Autor: Gabriel Müller Valadão \\ Orientador: Álvaro Nogueira de Sousa \\ Programa de Pós-Graduação em Ciências Florestais \\ Brasília, 25 de Fevereiro de 2016
}

O Cerrado é caracterizado por uma grande biodiversidade, no entanto vem sofrendo uma grande perda de sua área original, sendo necessário desenvolver pesquisas para estimular o uso sustentável dos recursos naturais. As vantagens do crescimento do comércio de produtos florestais não madeireiros devem-se, principalmente, à possibilidade de conciliar desenvolvimento à conservação da biodiversidade. A espécie baruzeiro possui características nutricionais e funcionais diferenciadas, nos últimos anos o comércio de suas castanhas vem se destacando como fonte geradora de renda para as famílias agroextrativistas. O objetivo desse estudo foi a análise econômica e financeira da produção de castanha de baru na região do vale do Rio Urucuia, inquirindo sobre a viabilidade econômica e financeira da atividade extrativista, caracterizando seu canal de comercialização, auferindo as margens brutas e mark-ups de comercialização. Foram caracterizados os processos produtivos, as variáveis técnicas, rendimentos operacionais, em especial os custos e receitas da atividade. Foi realizado um estudo acerca do efeito do ganho de escala com os indicadores econômicos utilizados, analisando a viabilidade de diferentes perfis de agroextrativistas. O extrativismo se mostrou viável economicamente em todos indicadores de rentabilidade, com exceção a receita líquida dos agroextrativistas médios na safra de 2014. Ao analisar a viabilidade financeira da atividade na perspectiva da execução um investimento, o extrativismo se mostrou viável somente para o coletivo de agroextrativistas. $O$ beneficiamento dos frutos mostrou-se determinante nos custos de produção e todos os indicadores econômicos responderam positivamente ao aumento de escala. Ao estudar as margens de comercialização, foi constatado que os agroextrativistas se apropriaram pouco das margens do valor final do produto ou em relação ao seu custo de produção, no entanto todos os fatores de produção, assim como seus custos, foram remunerados e geraram valores superiores ao custo de oportunidade.

Palavras-chave: Indicadores econômicos e financeiros, custos de produção, valor presente líquido 


\section{ABSTRACT}

\section{ECONOMIC ASPECTS OF THE BARU EXTRACTIVISM (Dipteryx alata Vog.)}

IN RIVER VALLEY URUCUIA, MINAS GERAIS.

Author: Gabriel Müller Valadão

Supervisor: Álvaro Nogueira de Sousa

Programa de Pós-graduação em Engenharia Florestal

Brasilia, February, 25, 2016

The Cerrado (Brazilian savanna) is characterized by large biodiversity and therefore is classified as one of the world's biodiversity hotspots. The benefits of the non timber forest products marketing increase are due to the possibility of joining economic development with biodiversity conservation and settling down of peasants in their rural areas. The species Baruzeiro has multiple uses. In recent years the commercialization of the Baru nuts has stood out as an income source for extractivist family farmers. This study aims to economically analyse the Baru nuts production in the Urucuia River valley area by inquiring on the feasibility of the extractivist activity and Baru nuts commercializtion. Extractivism has shown to be economically feasible for all profitability indicators with exception of the net income of the less productive farmers in the harvest of 2014. By analyzing the feasibility of the activity under the perspective of the implementation of an investment, extractivism has shown to be feasible only for collective and associative enterprises. The study of the trade margins indicated that the farmers is little appropriated the final selling value or the one related to the production costs, what highlights that all production factors as well as their costs were remunerated and generated values above opportunity costs.

Key words: economic indicators, profitability, net present value 


\section{SUMÁRIO}

1 - INTRODUÇÃO GERAL ........................................................................................................ 1

2 - OBJETIVOS ...................................................................................................... 2

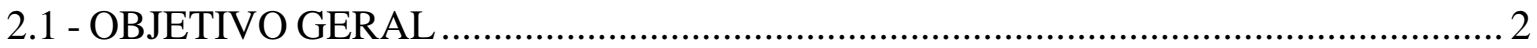

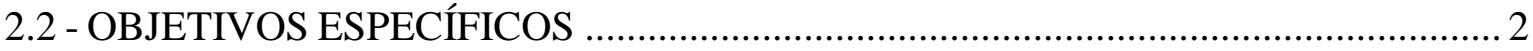

3 - REVISÃO DE LITERATURA ........................................................................3

3.1- PRODUTOS FLORESTAIS NÃO MADEIROS (PFNMS) …………………………... 3

3.2 - VIABILIDADE ECONÔMICA DOS PFNMS …………………………………...... 6

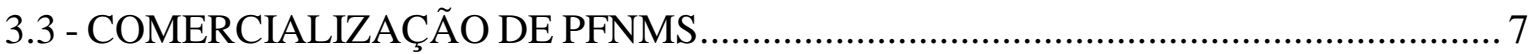

3.4 - BARU (DIPTERYX ALATA VOGEL) ………………………………………………..... 10

REFERÊNCIAS BIBLIOGRÁFICAS ............................................................................. 16

CAPÍTULO 1

1 - INTRODUÇÃO ............................................................................................................... 26

2 - OBJETIVOS ..................................................................................................... 27

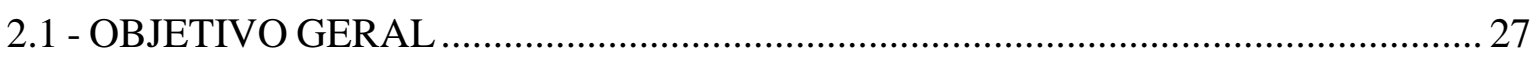

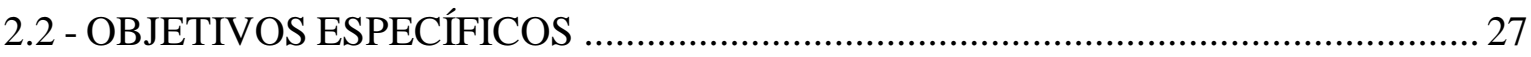

3 - MATERIAIS E MÉTODOS...............................................................................27

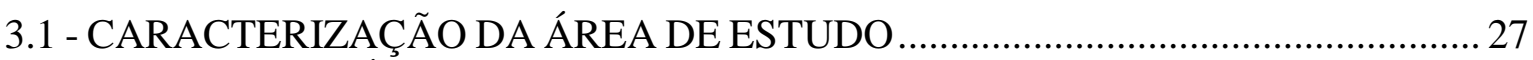

3.2 - COLETA E ANÁLISE DOS DADOS ……………………………………........ 28

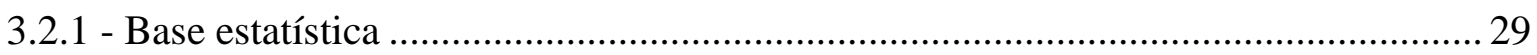

3.2.2 - Estrutura das Receitas .................................................................................. 30

3.2.3 - Estrutura de custos ...................................................................................... 31

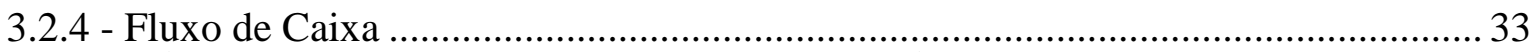

3.3 - ANÁLISE ECONÔMICA E FINANCEIRA E MÉTODOS UTILIZADOS ...................34

3.3.1 - Valor Presente Líquido (VPL) .......................................................................... 35

3.3.2 - Benefício Periódico Equivalente (BPE) ………………………………………......... 36

3.3.3 - Custo Médio de Produção (CMPr) ……………………………………………..... 37

3.3.4 - Remuneração da mão de obra familiar (RMOF) .......................................................... 37

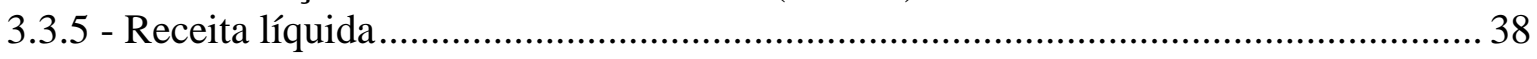

4 - RESULTADOS E DISCUSSÃO .............................................................................39

4.1 - PERFIL DOS AGROEXTRATIVISTAS …………………………………........... 39

4.2 - PROCESSO PRODUTIVO E COMÉRCIO DO BARU............................................ 42

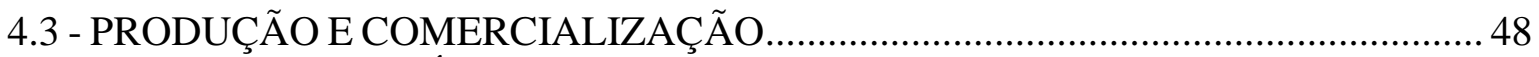

4.4 - COEFICIENTES TÉCNICOS DO SISTEMA PRODUTIVO …………………….... 52

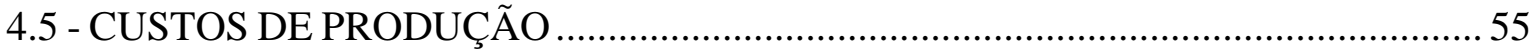

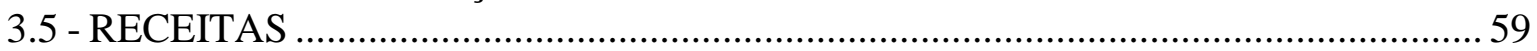

3.6 - ANÁLISE ECONÔMICA E FINANCEIRA ................................................................. 60

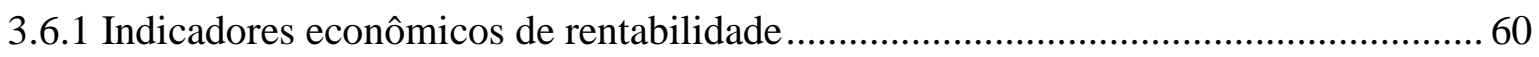

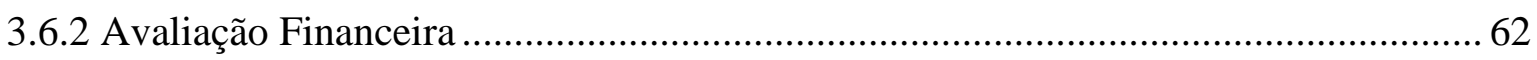

4 - CONCLUSÕES E RECOMENDAÇÕES .................................................................65 


\section{CAPÍTULO 2}

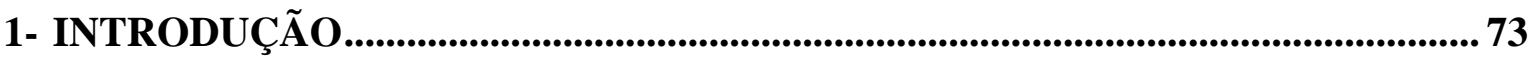

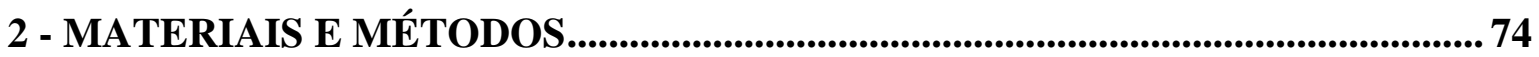

2.2 - CARACTERIZAÇÃO DA ÁREA DE ESTUDO........................................................ 74

2.3 - COLETA E ANÁLISE DOS DADOS ……………………....................................

2.4 - MARGENS DE COMERCIALIZAÇÃO ………………...................................... 76

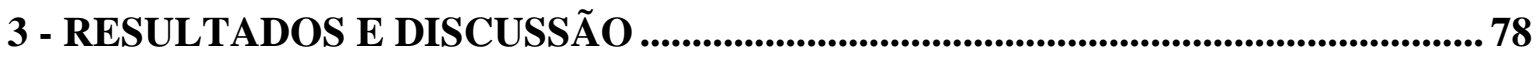

3.1 - RENDIMENTOS OPERACIONAIS E CADEIA PRODUTIVA …….......................... 78

3.2 - MARGEM E "MARKUP” DE COMERCIALIZAÇÃO ................................................. 81

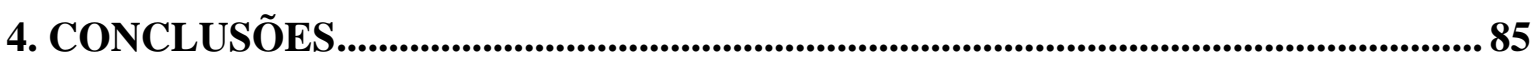

REFERÊNCIAS BIBLIOGRÁFICAS .......................................................................... 87

ANEXOS ................................................................................................................................. 89

ANEXO I - QUESTIONÁRIO ANÁLISE ECONÔMICA DAS FAMÍLIAS AGROEXTRATIVISTAS ..... 90 ANEXO II - QUESTIONÁRIO PARA VAREJISTAS E ATACADISTAS: COMERCIALIZAÇÃO DE

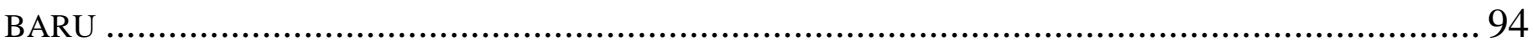

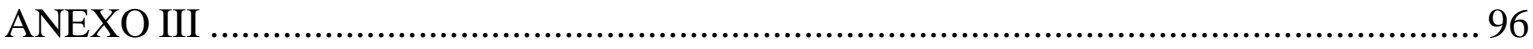

SÉRIE HISTÓRICA MENSAL DO IGP-DI DO HORIZONTE DE PLANEJAMENTO ADOTADO.............96

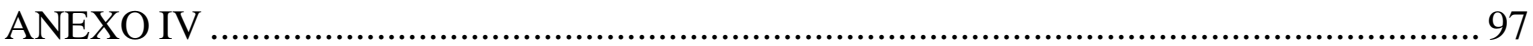

SÉRIE HISTÓRICA DOS CUSTOS VARIÁVEIS DOS AGROEXTRATIVISTAS MÉDIOS ........................99

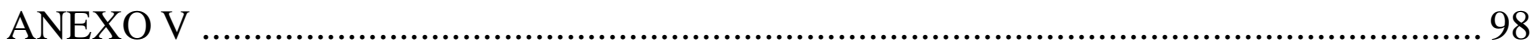

SÉRIE HISTÓRICA DOS CUSTOS VARIÁVEIS DOS AGROEXTRATIVISTAS MAIS PRODUTIVOS.....98

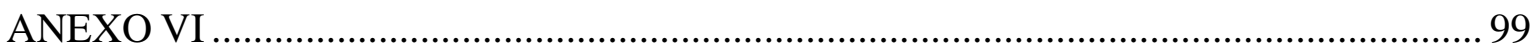

SÉRIE HISTÓRICA DOS CUSTOS VARIÁVEIS DO COLETIVO DE AGROEXTRATIVISTAS................99

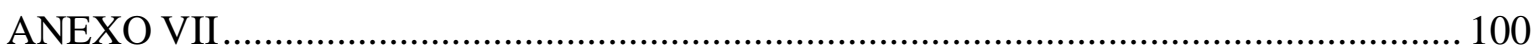

SÉRIE HISTÓRICA DOS VALORES DE MÃO DE OBRA, CUSTOS FIXOS E INVESTIMENTOS .......... 100 


\section{LISTA DE TABELAS}

\section{CAPÍTULO 1}

Tabela. 1- Número de entrevistas e atividades com renda por regiões estudadas ... 39

Tabela 2 - Renda anual e percentual da renda resultante do comércio do baru....... 41

Tabela 3 - Produção e preços praticados na safra e entressafra 2013/2014............. 49

Tabela 4 - Produção e preços praticados na safra e entressafra 2014/2015............. 50

Tabela 5 - Diferença na produção nas diferentes safras analisadas ......................... 50

Tabela 6 - Quantidades produzidas e número de agroextrativistas cooperados. ..... 52

Tabela 7 - Variáveis técnicas da etapa coleta de frutos. ..........................................53

Tabela 8 - Variáveis técnicas da etapa transporte interno. ....................................53

Tabela 9 - Coeficientes técnicos da etapa beneficiamento dos frutos. .....................54

Tabela 10 - Quadro resumo das variáveis técnicas dos serviços executados. ..........54

Tabela 11 - Custos variáveis da atividade extrativa ..............................................56

Tabela 12 - Custos fixos médios da atividade extrativa. ........................................56

Tabela 13 - Análise comparativa dos custos nas diferentes safras em estudo.........57

Tabela 14 - Rentabilidade do extrativismo para a Safra 2013/2014 ....................... 59

Tabela 15 - Rentabilidade do extrativismo para a Safra 2014/2015 ...................... 61

Tabela 16 - Quadro comparativo dos resultados encontrados na literatura. ............61

Tabela 17 - Indicadores de viabilidade que variam o valor do capital no tempo. .. 62

Tabela 1 - Indicadores de viabilidade que variam o capital no tempo............... 63

\section{CAPÍTULO 2}

Tabela 01 - Fórmulas usadas no cálculo da margem de comercialização (Mb) ..... 77

Tabela 02 - Fórmulas usadas no cálculo do markup (Mk).................................. 77

Tabela 03 - Valor recebido por dia de trabalho. .................................................. 81

Tabela 04- Margem bruta (Mb) e markup (Mk), da cadeia produtiva do baru........ 82 


\section{LISTA DE FIGURAS}

\section{CAPÍTULO 1}

Figura 1 - Distribuição do baru no bioma Cerrado.

Figura 2 - Diagrama do fluxo de caixa no período de tempo adotado. .34

Figura 3 - Renda principal declarada pelos entrevistados. 40

Figura 4 - Local de armazenamento e veículo mais utilizado no transporte. 43

Figura 5 - Tipos de veículos utilizados no transporte do baru ................................. 43

Figura 6 - Locais de armazenamento dos frutos coletados................................... 44

Figura 7 - Equipamentos mais utilizados para a quebra dos frutos. ...................... 45

Figura 8 - Recipientes para comercialização da castanha..................................... 46

Figura 9 - Porcentagens de agroextrativistas que são atendidos pela ATES. .......... 47

Figura 10 - Canais de comercialização dos agroextrativistas................................. 51

Figura 11 - Composição dos custos das safras analisadas.....................................57

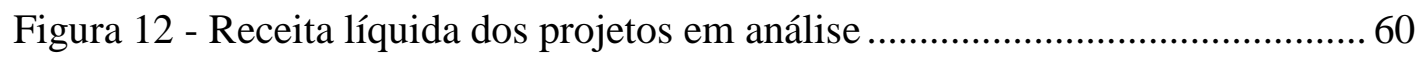

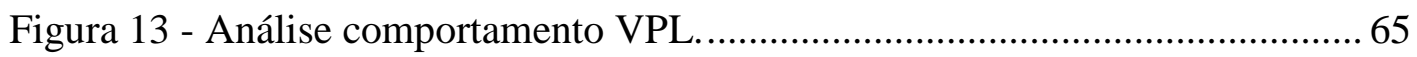

\section{CAPÍTULO 2}

Figura 1 - Fluxograma da cadeia produtiva do baru na região de estudo. 80 


\section{LISTA DE SIGLAS E ABREVIATURAS}

\begin{tabular}{|c|c|}
\hline ANOVA & - Análise de variância \\
\hline $\mathrm{BCB}$ & - Banco Central do Brasil \\
\hline $\mathrm{BPE}$ & - Benefício periódico equivalente \\
\hline $\mathrm{Cj}$ & - Custos no final do período de tempo considerado; \\
\hline CMPr & - Custo médio de produção \\
\hline CONAB & - Companhia Nacional de Abastecimento \\
\hline COPABASE & - Cooperativa da Agricultura Familiar Sustentável com Base na \\
\hline \multicolumn{2}{|c|}{ Economia Solidaria } \\
\hline CUP & - Custo Unitário de Produção \\
\hline CVP & - Ciclo de Vida do Produto \\
\hline CVPE & - Ciclo de vida do Produto extrativista \\
\hline DB & - Depreciação de benfeitorias \\
\hline $\mathrm{DM}$ & - Depreciação de máquinas e implementos \\
\hline FNDE & - Fundo Nacional de Desenvolvimento da Educação \\
\hline $\mathrm{H} / \mathrm{DF}$ & - Número diárias de mão de obra familiar \\
\hline HsTR & - Total de horas trabalhadas \\
\hline $\mathrm{i}$ & - Taxa de juros \\
\hline IGP-DI & - Índice geral de preços Disponibilidade Interna \\
\hline INCRA & - Instituto Nacional de Colonização e Reforma Agrária \\
\hline $\mathrm{j}$ & - Período em que as receitas ou os custos ocorrem \\
\hline LDL & - Low density lipoprotein \\
\hline PAA & - Programa de Aquisição de Alimentos \\
\hline PET & - Polietileno tereftalato \\
\hline PFNMs & - Produtos florestais não madeireiros \\
\hline PGPMBio & - Política de garantia de Preços Mínimos dos Produtos de \\
\hline \multicolumn{2}{|c|}{ Sociobiodiversidade } \\
\hline PNAE & - Programa Nacional de Alimentação Escolar \\
\hline PRONAF & - Programa Nacional de Fortalecimento da Agricultura Familiar \\
\hline PTj & - Produção total equivalente em cada período \\
\hline $\mathrm{Rj}$ & - Receita no final do período de tempo considerado \\
\hline
\end{tabular}




$\begin{array}{ll}\text { RL } & \text { - Receita líquida } \\ \text { RMOF } & \text { - Remuneração da mão de obra familiar } \\ \text { RTF } & \text { - Renda do trabalho familiar } \\ \text { SISVAR } & \text { - Sistema de Análise de Variância } \\ \text { t } & \text { - Número de períodos de capitalização } \\ \text { Tocup } & \text { - Taxa de ocupação do bem } \\ \text { VN } & - \text { Valor do bem novo } \\ \text { VN } & - \text { Valor do bem novo } \\ \text { VPL } & - \text { Valor presente líquido } \\ \text { VR } & - \text { Valor residual do bem } \\ \text { VR } & - \text { Valor residual do bem } \\ \text { VUA } & - \text { Vida útil do bem } \\ \text { VUH } & - \text { Vida útil definida em horas }\end{array}$




\section{1 - INTRODUÇÃO GERAL}

O Bioma Cerrado é constituído de relações ecológicas e fisionômicas com outras savanas da América tropical, da África e da Austrália, além do Sudoeste da Ásia. Ocorre em altitudes que variam de cerca de $300 \mathrm{~m}$, a exemplo da baixada Cuiabana, em Mato Grosso, a mais de $1.600 \mathrm{~m}$, na Chapada dos Veadeiros, em Goiás. No Brasil está localizado essencialmente no Planalto Central, é o segundo bioma do país em área, apenas superado pela Floresta Amazônica (RIBEIRO e WALTER, 2008). O Cerrado é caracterizado por uma grande biodiversidade (ZAIDAN e CARREIRA, 2008), listado como um dos 34 ecossistemas mais ameaçados do mundo (MITTERMEIER et al., 2004).

A utilização dos produtos florestais não lenhosos de origem vegetal como alternativa econômica em meio à exploração madeireira predatória colabora para a sustentabilidade (RÊGO, 2014). As vantagens do crescimento dessa atividade devem-se, principalmente, à possibilidade de conciliar desenvolvimento econômico aliado à conservação do meio ambiente e manutenção das populações em suas regiões de origem (ALMEIDA et al., 2009).

O uso e a comercialização dos produtos florestais não madeireiros do baru (Dipteryx alata Vog.) vêm proporcionando melhorias na renda das famílias envolvidas. Essa espécie é nativa do bioma Cerrado, e promissora para implantação de florestas de proteção e produção. Possui usos múltiplos, dentre eles, o alimentar, madeireiro, medicinal, industrial, paisagístico e na recuperação de áreas degradadas (ALVES et al., 2010).

Recentemente, esta espécie tem atraído interesse científico por causa da composição nutricional da castanha (BENTO et al., 2014), uma vez que possui a propriedade de proteger os tecidos contra o estresse oxidativo induzido pelo ferro e o ácido fítico (SIQUEIRA et al., 2012). Pode ser utilizada para consumo humano como fonte de proteína de qualidade e compostos bioativos, em dietas saudáveis e alimentos processados (SIQUEIRA et al., 2015).

Estudos sobre a economia extrativista, que analisem a importância na renda dos agricultores familiares, assim como a sua viabilidade econômica e financeira são escassos, em especial no Cerrado. A produção da castanha de baru é proveniente do extrativismo 
vegetal, geralmente praticados por agricultores familiares, que utilizam a comercialização para complementar sua renda (PIMENTEL et al., 2009).

Dentro do exposto esse estudo tem o objetivo de analisar os aspectos econômicos da produção extrativista da castanha do baru, na região Noroeste de Minas Gerais, estudando os coeficientes técnicos, variáveis técnicas e rendimentos operacionais, realizando uma análise econômica e financeira do extrativismo do baru.

Essa Dissertação foi dividida em dois capítulos, iniciando com uma revisão de literatura sobre os produtos florestais não madeireiros (PFNMs), viabilidade econômica e comercialização de PFNMs e sobre o Baru (Dipteryx alata Vog.). Os capítulos foram divididos em Capítulo 1: Viabilidade financeira do extrativismo do baru (Dipteryx alata vogel) na formação da renda dos agroextrativistas de Arinos/MG e Capítulo 2: O mercado da castanha de baru (Dipteryx alata Vogel.) na mesorregião do noroeste de Minas Gerais.

\section{2 - OBJETIVOS}

\section{1 - OBJETIVO GERAL}

Analisar economicamente a produção de castanha de baru (Dipteryx alata vogel) na mesorregião Noroeste de Minas Gerais.

\section{2 - OBJETIVOS ESPECÍFICOS}

- Analisar o perfil produtivo dos agroextrativistas de castanha de baru, caracterizando seu processo produtivo, rendimentos operacionais, custos e receitas advindas da atividade;

- Avaliar a viabilidade econômica e financeira do extrativismo do baru na região do Vale do Urucuia, Minas Gerais;

- Estudar o efeito da escala de produção na viabilidade de diferentes projetos agroextrativistas;

- Caracterizar o canal de comercialização e estimar as margens de comercialização do comércio do baru na mesorregião de Arinos. 


\section{3 - REVISÃO DE LITERATURA}

\section{1- PRODUTOS FLORESTAIS NÃO MADEIROS (PFNMs)}

O Cerrado é uma prioridade para a conservação (MYERS, 2003), mas também é a principal fronteira agrícola do agronegócio brasileiro (BRUGNARO e BACHA, 2009), essa aparente contradição demonstra a importância de realização de estudos sobre atividades econômicas que utilizem sustentavelmente os recursos naturais, uma vez que a valorização dessa biodiversidade constitui-se em um forte motivo para preservá-la (AFONSO, 2009).

A valorização dos recursos florestais restrita à produção madeireira vem sendo modificada dentro de um contexto macroeconômico, tornando-se cada vez mais visível a relevância de outros produtos e serviços (SANTOS et al., 2003). Nesse contexto as mudanças causadas por pressões de organizações ambientalistas, que somados a fatores econômicos, catalisaram o interesse da ciência e de governos contemporâneos para os produtos florestais não madeireiros (PFNMs) (FIEDLER et al., 2008).

Essa preocupação é devida a relevância dos PFNMs na renda das famílias, estima-se que esses produtos somam até $25 \%$ da renda de um bilhão de pessoas no mundo aproximadamente (SANTOS e GUERRA, 2010).

Não existe uma definição única de PFNMs, alguns autores utilizam conceitos muito restritivos, como extrativismo de plantas na floresta excluindo a madeira (CROITORU, 2007, SCHAAFSMA et al., 2012;), outros incluem produtos provenientes de sistemas agroflorestais e plantações (SHANLEY et al., 2006), que incluem plantas medicinais, frutas, castanhas, resinas, látex, óleos essenciais, fibras, forragem, fungos, fauna e madeira para fabricação de artesanato.

A utilização dos PFNMs é tão antiga como a existência humana, em economias rurais de subsistência o papel e as contribuições dos PFNMs na vida diária de pessoas são cruciais (ANGELO et al., 2012). 
A exploração dos PFNMs faz parte da história econômica brasileira. No Século XVII, o Estado do Maranhão e Grão-Pará, já se constituíam em um imenso empório de produtos florestais, as chamadas "drogas do sertão" (SILVA, 1990). A produção de PFNMs ocorre via processo extrativista, que sempre foi entendida como a primeira forma de exploração econômica, limitando-se a coleta de produtos existentes na natureza, com baixa produtividade ou com produtividade declinante (HOMMA, 1993)

O extrativismo é uma maneira de produzir bens, em que, os recursos naturais úteis são retirados diretamente da sua área de ocorrência natural. A caça, a pesca e a coleta de produtos vegetais são os três exemplos clássicos de atividades extrativas (DRUMMOND, 1996).

As primeiras pesquisas sobre PFNMs incluem o relatório da Organização Internacional de Madeira Tropical (ITTO, 1988), o interesse por estes produtos foi motivado principalmente pela constatação da sistemática redução da área mundial de florestas tropicais, alterando o uso do solo, sobretudo para fins agropecuários (BALZON, 2006).

A sustentabilidade da atividade extrativa de PFNMs é questionada por alguns pesquisadores e defendida por outros (ALMEIDA et al., 2012). Os defensores destacam a importância na geração de renda e principalmente na diminuição da pobreza para as populações dos trópicos (KAR e JACOBSON, 2011; KLIMAS et al., 2012; SHANLEY et al., 2006). Outra vantagem do trabalho com os PFNM é proporcionar acessos a capacitações que estimulam a criação de organizações comunitárias (AFONSO et al., 2015).

Os autores mais críticos ao extrativismo destacam fatores limitantes à economia destes produtos, em especial a sazonalidade da produção, que provoca oscilações na oferta, consequentemente fragmentando as relações comerciais (NOGUEIRA et al., 2009; MAGALHÃES, 2014). Outras restrições são as dificuldades históricas de organização dos agricultores, extração predatória, falta de cuidados com manuseio, preço de mercado mais baixo que o custo de produção (ALMEIDA et al., 2012).

Outros fatores que contribuem para o declínio da atividade extrativa são a oferta inelástica da produção, taxas de coleta que excedam as taxas de regeneração, domesticação do 
produto florestal e o desenvolvimento industrial de substitutos para o produto (HOMMA, 2008).

O extrativismo, segundo Homma (2012), constitui um ciclo econômico constituído de três fases distintas. Na primeira fase, verifica-se um crescimento na extração, principalmente com o crescimento da demanda. Na segunda fase atinge-se o limite da capacidade, em face aos estoques disponíveis e do aumento no custo da extração. Na terceira fase, inicia-se o declínio na extração, com o esgotamento das reservas e o aumento na demanda, induzindo ao início dos plantios, desde que a tecnologia de domesticação esteja disponível e seja viável economicamente (HOMMA, 2012).

Entretanto as teorias de Homma quanto à inviabilidade do desenvolvimento de uma economia baseada no extrativismo para a Amazônia, motivada pela existência do Ciclo de vida do Produto extrativista/CVPE, não se sustentam, pois ela é plenamente compatível com o Ciclo de Vida do Produto/CVP, e para este, existem a possibilidades de desenvolvimento econômico e comercial de produtos em todas as suas fases (CALDEIRON, 2013).

Mesmo com todas as limitações inerentes ao proceso de produção extrativista, oportunidades comerciais para os PFNMs são emergente em todo o mundo, principalmente pela liberalização econômica está abrindo novos mercados, a descentralização governamental e a democratização estão viabilizando comunidades a ter um papel mais importante na gestão dos recursos florestais (NEUMANN e HIRSCH, 2000).

Por esse motivo o desenvolvimento de produtos que possam ser extraídos e comercializados a um bom preço de mercado permite a consolidação e o desenvolvimento de projetos relacionados à exploração de espécies nativas (PRIMACK e RODRIGUES, 2001).

Ao estudar o extrativismo na região vale do Urucuia, Bispo e Diniz (2014) caracterizaram o agroextrativismo do vale do Urucuia como atividade pluriativa, contribuindo para permanência das famílias em suas propriedades, além de cumprir múltiplas funções no meio rural. 
Geralmente as famílias extrativistas, também praticam atividades agrícolas, por esse motivo são conhecidos como agroextrativistas, nesse caso existe a complementariedade das duas atividades que são praticadas no meio rural, que são a agricultura, pecuária e o extrativismo (BISPO e DINIZ, 2014).

Para promover o uso sustentável dos recursos naturais, estimulando o uso e o comércio de PFNMs, é preciso que a atividade extrativa, seja viável economicamente, socialmente e ambientalmente. Atendendo esses princípios, o extrativismo permitirá melhorias na renda das famílias extrativistas, mantendo as taxas de regeneração da espécie, contribuindo para fixar o homem no campo e diminuindo os inchaços dos grandes centros urbanos.

\section{2 - VIABILIDADE ECONÔMICA DOS PFNMs}

Para estudar os aspectos econômicos do extrativismo do baru no Vale do Urucuia é preciso analisar os fatores de produção, as variáveis técnicas e os rendimentos operacionais da atividade. $\mathrm{O}$ teste de viabilidade econômica consiste em verificar se as receitas inerentes ao projeto superam os custos necessários. Tantos os custos como as receitas são valores diretos observados do ponto de vista privado (Resende e Oliveira, 2013).

A análise econômica de um investimento envolve o uso de técnicas e critérios de análise que comparam os custos e as receitas inerentes ao projeto, visando decidir se este deve ou não ser implementado (Resende e Oliveira, 2013). O estudo da viabilidade econômica de projetos agroindustriais permite que os agricultores familiares construam juntos, alternativas de desenvolvimento em bases sustentáveis, não ficando presos somente à análise econômica, técnica e financeira, mas levando em consideração também os aspectos social, cultural e ambiental do grupo e da região (COSTA, 2012).

Para Resende e Oliveira (2013) a análise econômica de um investimento é toda aplicação de capital em qualquer empreendimento, com a finalidade básica de obter receitas, observando se tanto os custos como as receitas são valores diretos. Assim, supõe-se que todos os insumos e produtos relacionados com o projeto possam ser quantificados em termos monetários. A viabilidade financeira consiste em verificar se há recursos suficientes (capital, terra, mão de obra, etc.) para a implementação do projeto (RESENDE e OLIVEIRA 2013). 
A viabilidade econômica de um projeto analisada pelo método do valor presente líquido (VPL) é indicada pela diferença positiva entre receitas e custos atualizados à uma determinada taxa de desconto; (SILVA et al., 2008). Um VPL positivo indica que o projeto é economicamente viável para uma determinada taxa utilizada. O melhor será aquele que apresentar maior VPL. Deve-se aceitar o investimento com VPL maior que zero (positivo) e, consequentemente, rejeitar aquele com VPL negativo (RÊGO, 2014).

O Custo médio de produção (CMPr) é utilizado quando se deseja operar com o custo médio mínimo, independente da quantidade produzida e do tempo de duração do investimento. $\mathrm{O}$ custo médio de produção resulta na relação entre o custo total atualizado $\left(\mathrm{CT}_{\mathrm{j}}\right)$ e a produção total equivalente $\left(\mathrm{QT}_{\mathrm{j}}\right)$. Para saber se o projeto é viável, deve-se comparar o CMPr de uma unidade como valor de mercado do produto (RESENDE e OLIVEIRA 2013).

Estimativas financeiras para o extrativismo em áreas naturais dão conta de valores brutos de R\$ 2.250,00/ha/ano para a comercialização da geléia da polpa de cagaita; R\$ 800,00/ha/ano para frutos e R\$1.200,00/ha/ano para a polpa de araticum e de R\$ 420,00/ha/ano para a comercialização de amêndoas torradas de baru (BRASIL, 2005).

Ao analisar as lições e recomendações acerca da viabilidade econômica de negócios sustentáveis da biodiversidade em áreas protegidas, Alvarenga e Reid (2014) evidenciam que é urgente a ampliação da rentabilidade de atividades produtivas sustentáveis, para que sejam efetivas na promoção da qualidade de vida de comunidades tradicionais da Amazônia.

Questões referentes a conservação e a preservação dos recursos naturais perpassam pelo aumento da renda liquida, tendo em vista que a pobreza delibera caráter secundário às ações conservacionistas. Assim, em curto prazo a criação de mercados para os produtos extrativos dariam viabilidade econômica ao processo (HOMMA, 1993).

\section{3 - COMERCIALIZAÇÃO DE PFNMS}


Extrativismo vegetal foi a primeira atividade de importância econômica do Brasil. Por mais de três séculos, do século XVI até o início do XIX, o pau-brasil (Caesalpinia echinata Lan) foi tido como um dos principais itens de exportação do país, quando era utilizado como corante e na indústria de móveis finos na Europa. Porém, com a coleta indiscriminada da espécie, o mesmo entrou em colapso aproximadamente no final do século XIX (HOMMA, 2008).

Inicialmente a comercialização de PFNMs começou no Bioma Amazônico. Homma (2012) afirma que os produtos derivados do extrativismo tiveram sua importância econômica modificada com o passar dos anos. As "drogas do sertão" e o cacau (Theobroma cacao L.) tinham preços valorizados na Europa no período colonial. Posteriormente a borracha (Hevea brasiliensis M.) teve dois ciclos de extração importantes, no final do século XIX e no período da II Guerra Mundial, tendo sido geradora de riquezas para os fazendeiros e intermediários da produção.

A comercialização não consiste apenas na venda da produção em um determinado mercado. Ela é mais do que isto, caracterizada como um processo contínuo e organizado de encaminhamento da produção agrícola ao longo de um canal ou sistema de comercialização, onde o produto sofre transformações, diferenciações e agregações de valor. As facilidades (utilidades) que os produtos agrícolas sofrem são de posse, forma, tempo e lugar, adequando-os, desta forma, ao gosto e preferência dos consumidores finais (MENDES e PADILHA JÚNIOR, 2007).

Estudos acadêmicos apontam que a comercialização dos PFNMs é um instrumento para promover a conservação da floresta e melhorias no bem-estar dos moradores da região por meio de melhoria na renda (NEUMANN e HIRSH, 2000; RIZEK e MORSELLO, 2012).

Já foram identificadas, previamente, mais de 200 espécies vegetais no Cerrado que possuem um bom potencial econômico, como o baru (Dipteryx alata Vog.), o araticum (Annona crassiflora Mart.), a mangaba (Hancornia speciosa Gomes), o pequi (Caryocar brasiliense Camb) e a cagaita (Eugenia dysenterica Mart. ex. D.C.), (BRASIL, 2005).

Muitas espécies não foram devidamente estudadas, carecendo de informações sobre seu valor, quantidades produzidas, processos de produção (manejo e conservação), 
comercialização e industrialização de seus produtos. Além disso, a sazonalidade e a variação em sua produção geram uma lacuna de dados, que dificulta a conservação e o desenvolvimento de seus mercados (ZAMORA, 2001).

O extrativismo é a principal fonte de obtenção de PFNMs da biodiversidade brasileira (PIMENTEL et al., 2009). Para a avaliação da importância da atividade extrativista, tornase imprescindível o estudo dos custos com coleta, processamento e transporte. Além disso, é necessário avaliar os preços no varejo, bem como a aceitação do produto, visando o planejamento de uma estratégia de produção e comercialização de seus produtos (VIEIRA et. al, 2006).

Para o sucesso da atividade extrativista, esta tem que ser transparente equitativa e sustentável, que produza um impacto positivo na redução da pobreza, e na igualdade de gênero, acesso, posse e a gestão dos recursos (MARSHALL et al., 2000).

A produção extrativa de PFNMs vem trazendo valores significativos ao país, bem como, essa atividade representa uma importante estratégia de desenvolvimento econômico para as comunidades extrativistas (AFONSO, 2012).

A indústria cosmética e de higiene pessoal estão entre os responsáveis pelo crescimento do comércio de PFNMs. Há uma tendência do mercado em buscar produtos da sociobiodiversidade para atender esse nicho de mercado (CALDEIRON, 2013).

Os produtos extrativos devem obter vantagem junto ao mercado explorando sua origem, forma de produção e benefícios gerados à preservação ambiental, destacando a qualidade do produto orgânico e sustentável, evitando rivalizar com substitutos industriais e procurando consumidores dispostos a pagar por essas qualidades diferenciadas. Por esse motivo deveria haver um maior investimento público nas áreas de infraestrutura, acesso a mercados e crédito para a produção e comercialização (CALDEIRON, 2013).

Novas políticas públicas estão sendo instituídas, aliado ao suporte do meio acadêmico, com a realização de pesquisas sobre as múltiplas dimensões em que a agricultura familiar está inserida. A possibilidade de acessar os mercados institucionais é uma alternativa de aproximar do consumo a produção de base familiar (PAULA et al., 2014). 
Entre os principais instrumentos de políticas de compras públicas estão o Programa de Aquisição de Alimentos (PAA) e o Programa Nacional de Alimentação Escolar (PNAE). O PAA foi instituído pela Lei $\mathrm{n}^{\circ} 10.696$, de 2003, e tem como finalidade incentivar a agricultura familiar, compreendendo ações vinculadas à distribuição de alimentos para pessoas em situação de insegurança alimentar e à formação de estoques estratégicos (BRASIL, 2003). Já o PNAE estabelece que um percentual de $30 \%$ dos recursos do Fundo Nacional de Desenvolvimento da Educação (FNDE), repassados aos municípios pelo Programa Nacional de Alimentação Escolar (PNAE), devem ser destinados à aquisição de alimentos produzidos pela agricultura familiar (PAULA et al., 2014).

Outra ação de valorização da produção extrativista foi a Política de Garantia de Preços Mínimos da Sociobiodiversidade (PGPM-BIO), que prevê a subvenção direta ao extrativista caso este efetue a venda de seu produto por preço inferior ao preço mínimo fixado pelo Governo Federal (BRASIL, 2009).

No entanto apesar das políticas públicas favoráveis disponíveis, os agroextrativistas e suas organizações possuem dificuldades em acessar essas políticas. Ao estudar a cadeia produtiva do baru, Magalhães (2014) observou um marco regulatório bastante confuso e incompleto, os agricultores sofrem com a falta de informações sobre o comportamento do mercado e com a falta de domínio das etapas de processamento e beneficiamento do produto.

\section{4 - BARU (Dipteryx alata Vogel)}

Classificada botanicamente como um membro da família Fabaceae (FERNANDES et al., 2010), o baruzeiro é uma árvore com altura média de 15 metros, podendo alcançar mais de $25 \mathrm{~m}$. O formato da copa varia de alongada e arrendondadda, de $6 \mathrm{~m}$ a $11 \mathrm{~m}$ de diâmetro. A casca do tronco é lisa, de cor cinza-clara ou creme, com estrias transversais, apresenta placas de formato irregular descamantes, deixando reentrâncias de cor creme (SANO et al., 2010).

As folhas são imparipenadas, alternas e espiraladas, com 7 a 13 folíolos alternos, oblongos; de até $10 \mathrm{~cm}$ de comprimento e $5 \mathrm{~cm}$ de largura. Nervuras secundárias salientes na fae 
inferior; pecíolo e raque alados, folíolos coriáceos; discolores, com glândulas trasnlúcidas (SILVA JÚNIOR, 2005).

Os frutos e sementes de espécies tropicais possuem grandes variações biométricas (ZUFFO et al., 2015; GONÇALVES et al., 2013). Em experimento de Ferreira et al. (1998) observou-se 1.190 sementes por quilograma, diferindo dos resultados de Carvalho (1994) que aferiu o resultado de 600 a 700 sementes por quilograma.

O fruto é do tipo legume drupóide, monospérmico, indeiscente, geralmente ovóide, fibroso, cor variando de bege escuro a marrom-avermelhado, opaco, superfície irregular apresentando algumas depressões, textura lisa; com ápice (FERREIRA et al., 1998).

O pericarpo é bem distinto, o epicarpo é fino, de consistência macia e quebradiça; o mesocarpo é marrom, consistência macia, farináceo, espesso, constituindo a polpa; endocarpo lenhoso, amarelo-esverdeado ou marrom com uma camada esponjosa na parte interna arredondada (FERREIRA et al., 1998).

Árvore decídua, sua floração ocorre entre novembro e fevereiro, frutificando de janeiro a março. Ocorre no cerrado sentido restrito, cerradão mesotrófico e matas secas. Ocorre no Distrito Federal e nos estados da Bahia, Goiás, Maranhão, Minas Gerais, Mato Grosso, Mato Grosso do Sul, Piauí, São Paulo e Tocantins (figura 1), (RATTER et al., 2000; SILVA JÚNIOR, 2012).

O baru é uma das poucas espécies que apresentam frutos com polpa carnosa durante a estação seca no Bioma Cerrado, sendo espécies importante para alimentação da fauna nessa época. Os morcegos consomem a polpa, e os primatas, incluindo os humanos, consomem tanto a polpa quanto as sementes, sendo consumido tambem por araras, cotias, gado bovino, cupins e formigas (SANO et al., 2004).

A espécie é heliófita, com hábito que varia de fuste retilíneo a levemente tortuosa, com crescimento simpodial ou monopodial (CARVALHO, 2003), sendo alógama e autocompatível, porém apresenta mecanismos para evitar ou reduzir a autopolinização espontânea como a presença de película estigmática que impede a germinação do pólen (OLIVEIRA e SIGRIST, 2008). 


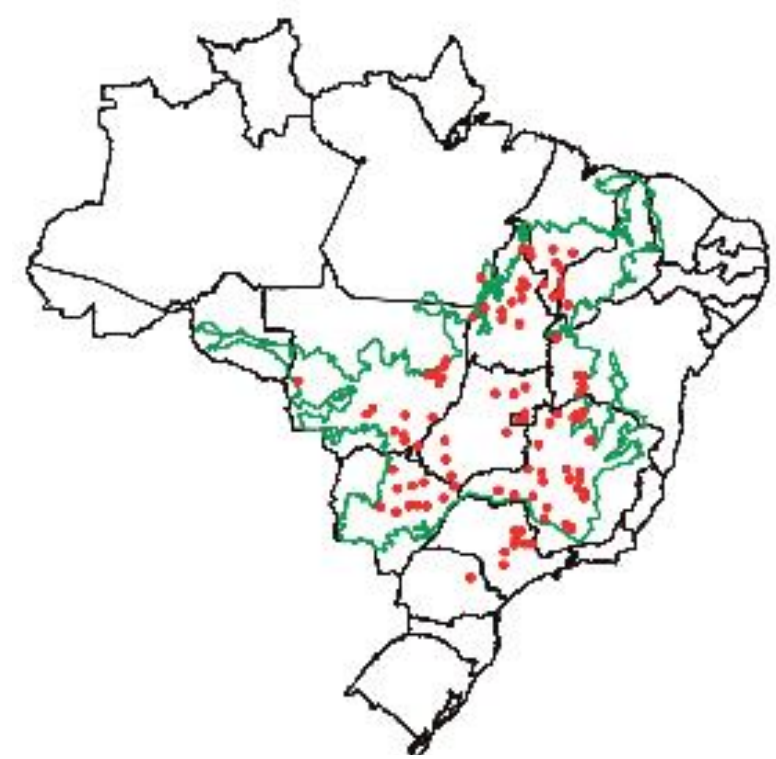

Figura 1 - Distribuição do baru no bioma Cerrado (RATTER et al. 2000).

As sementes de baru possuem comportamento ortodoxo em relação à longevidade no armazenamento, apresentando boa conservação da viabilidade, quando submetidas a baixa temperatura durante 12 meses de armazenamento, favorecendo a comercialização do produto (BOTEZELLI et al., 2000).

A amêndoa de baru torrado é usada na alimentação como ingrediente em doces e, mais recentemente, na gastronomia. O sabor da amêndoa de baru é semelhante ao do amendoim, no entanto é mais suave ao paladar. Por esta razão, tem se mostrado especialmente popular na região Centro Oeste de Brasil (FERNANDES et al., 2010).

Foram encontradas substâncias antinutricionais como tanino, ácido fítico e inibidor de tripsina. O tanino é encontrado na polpa e decresce com a maturação e o inibidor de tripsina pode ser inativado com a torragem da semente (SANO et al., 2004).

As sementes são boas fontes de macro e micronutrientes essenciais (TAKEMOTO et al., 2001), possuidora de altos teores de nutrientes, como proteínas e aminoácidos essenciais, além de uma quantidade apreciável de cálcio, níveis elevados de Ferro, Zinco e fibras (FREITAS, 2009; VERA et al., 2009; FERNANDES et al., 2010). 
Resultados indicam que as sementes oleaginosas nativas brasileiras, especialmente o baru, tem grande potencial para uso na dieta na prevenção e controle da dislipidemia, doença caracterizada pela presença de níveis elevados de lipídios no sangue (FERNANDES et al., 2015). A amêndoa de baru torrada possui perfil de ácidos graxos mono e poli-insaturado favorável à saúde (FREITAS, 2009).

Ao estudar as propriedades funcionais do baru, Guimarães et al. (2012) concluíram que a castanha do baru pode ser explorada para o aproveitamento das frações proteicas e lipídicas, indicando a possibilidade de emprego em diversos alimentos.

Dietas que possuem o baru em sua composição ajudam na redução do colesterol total e LDL (low density lipoprotein), causadores de doenças cardiovasculares. Em experimento de Bento et al., (2014) foram necessárias somente uma porção de 20g de baru para uma redução dos níveis desses lipídios, uma porção de 3 a 5 vezes menor que outras oleaginosas.

A polpa do baru pode ser considerada fonte importante de açúcares e fibra alimentar. Em testes de aceitabilidade os biscoitos obtiveram notas satisfatórias, tanto para sabor quanto para aparência, e verificou-se melhora na qualidade nutricional (ALVES et al., 2010). Essa característica proporciona a sua utilização na indústria alimentícia, permitindo o uso em panificados, barras de cereais, entre outros.

A amêndoa de baru torrada apresentou maior teor de fibras e cinzas, quando comparada ao amendoim torrado. $\mathrm{O}$ aumento do percentual de amêndoa de baru em paçocas reduziu o teor de lipídios, o valor energético total, aumentando a concentração de fibras e elevou a aceitação global (SANTOS et al., 2012). Pães desenvolvidos com diferentes proporções de casca e polpa de baru em substituição ao farelo de trigo apresentam aceitação quanto aos atributos de aparência, textura e sabor (ROCHA; SANTIAGO, 2009).

A utilização do baru aponta para um potencial de aplicação no nicho de mercado de alimentos orgânicos e funcionais, aliando inovações tecnológicas, segurança alimentar e desenvolvimento econômico e social do Cerrado (MARTINS, 2010), sendo uma excelente opção para uma dieta saudável (FERNANDES et al., 2010). 
Essa espécie é um dos principais PFNMs comercializado na mesorregião do Noroeste de Minas Gerais, sua produção é obtida mediante o extrativismo, proporcionando uma importante fonte de renda para as famílias envolvidas.

Considerando a importância do baru na economia das regiões produtoras, o Governo Federal inseriu essa espécie na lista dos produtos atendidos pela Política de Garantia de Preços Mínimos de Produtos da Sociobiodiversidade (PGPM-Bio).

O processo extrativista sempre foi entendido como a primeira forma de exploração econômica, limitando-se à coleta de produtos existentes na natureza, com baixa produtividade ou com produtividade declinante (HOMMA, 1993). Dessa forma, Homma (2012) considera que, para os produtos extrativos alimentícios que apresentem conflitos entre a oferta e a demanda, é urgente promover a sua domesticação.

Outra limitação da atividade extrativa está na variação e sazonalidade da produção. Para proporcionar o desenvolvimento dos mercados é necessário realização de estudos, principalmente quantidades produzidas, processos de produção (manejo e conservação), comercialização e industrialização de seus produtos (ZAMORA, 2001).

Diante do exposto a produção do baru não deve ser abordada somente sobre a perspectiva do extrativismo. Estudos acerca do comportamento do baru em condições de plantio racional devem ser estimulados, pois a espécie possui um bom potencial silvicultural. $\mathrm{O}$ baru é uma espécie de uso múltiplo (SANO et al., 2004) e está entre as 10 mais promissoras para cultivo (NEPOMUCENO, 2006).

O comportamento em viveiro é satisfatório, a semente de baru possui alta taxa de germinação e de estabelecimento de mudas (SANO et al., 2004). Estudando a germinação Almeida et al. (2014) obtiveram um resultado médio de 93,06\% de sementes germinadas, Corrêa et al. (2000), observaram uma germinação média de 97,02\%.

O baru apresenta desrama natural e possui a capacidade de emitir brotos, podendo ser plantado a pleno sol, em plantio puro, onde apresenta comportamento silvicultural satisfatório. Seu crescimento é moderado, podendo atingir incremento médio de 7,3 
$\mathrm{m}^{3} /$ ha/ano. Pode ser recomendado para arborização de pastagens, sistemas agroflorestais, arborização urbana, entre outros (CARVALHO, 2003).

Para a implantação florestal o espaçamento entre árvores deve ser definido conforme a finalidade do plantio. Para a produção de frutos, a copa do baru deve receber o máximo de sol. Considerando que a copa alcança cerca de 8 metros, a princípio esse deveria ser o espaçamento. Para fins madeireiros sugerem-se um plantio espaçado de 3 x 1,5 m com a realização do desbaste aos dez anos (SANO et al., 2004).

Muitas melhorias de ordem tecnológica precisam ser adotadas, uma vez que diversos pontos do processo produtivo são carentes de tecnologia, com potencial para melhorias e otimizações dos processos, agregando valor aos subprodutos (PIMENTEL et al., 2009; MARTINS et al., 2009).

A produção das castanhas de baru possui um custo relativamente elevado, principalmente devido às suas condições artesanais de coleta e processamento (FERNANDES et al., 2015). Pesquisas e desenvolvimentos de equipamentos e processos no beneficiamento do baru podem favorecer as famílias envolvidas e as empresas inovadoras que exploram os recursos naturais de forma sustentável (MARTINS et al., 2009).

Os obstáculos que as organizações da cadeia produtiva do baru enfrentam, podem constituir em poderoso entrave à sua adequada gestão, contribuindo também para o comprometimento da sustentabilidade da atividade de exploração da amêndoa do baru (MAGALHÃES, 2014). 


\section{REFERÊNCIAS BIBLIOGRÁFICAS}

AFONSO, S. R.; ANGELO, H. Mercado dos produtos florestais não-madeireiros do cerrado Brasileiro. Ciência Florestal, Vol. 19, nº. 3, p. 317-328, 2009.

AFONSO, S. R. A política pública de incentivo à estruturação da cadeia produtiva do pequi (Caryocar brasiliense). 2012. 162 f. Tese (Doutorado em Ciências Florestais) Universidade de Brasília, Brasília, 2012.

AFONSO, S. R.; ANGELO, H.; ALMEIDA, A. N. de. Caracterização da produção de pequi em Japonvar, MG. Floresta, Curitiba, v. 45, n. 1, p. 49 - 56, 2015.

ANGELO, H.; POMPAMAYER, R. S.; VIANA, M. C.; ALMEIDA, A.N. de.; MOREIRA, J. M. M. A. P.; SOUZA, A. N. Valoração econômica da depredação do Pequi (Caryocar brasiliense Camb.) no Cerrado brasileiro. Scientia Forestalis, Piracicaba, v. 40, n. 93, p. 035-045, 2012.

ALMEIDA, S. P.; PROENÇA, C. E. B.; SANO, S. M. \& RIBEIRO, J. F. 1998. Cerrado: Espécies vegetais úteis. Planaltina, EMBRAPA-CPAC.

ALMEIDA, A. N.; BITTENCOURT A. M.; SANTOS, A. J. dos.; EISFELDI C.L.; SOUZA, V.S. Evolução da produção e preço dos principais produtos florestais não madeireiros do Brasil. Cerne, Lavras, v. 15, n. 3, p. 282-287, 2009.

ALMEIDA, L. S. de., GAMA, J. R. V., FERREIRA, M. S. G., HOMMA, A. K. O., MENEZES, J. E. A. de. Mercado de produto florestal não madeireiro em Santarém, Pará, Brasil. Juá FOPIESS, v.01, p. 09-17, 2012.

ALMEIDA, L. A. P.; MOURA, F. C. S.; VALADÃO, G. M.; BEZERRA NETO, F. V. RAMOS, C. R.; LINO, T. M. Efeito de diferentes proporções de substrato orgânico no estabelecimento de mudas de Dipteryx alata Vog. (Baru). In: III seminário de iniciação científica do IFNMG, 2014, Januária. III Seminário de iniciação científica do IFNMG, 2014.

ALVARENGA, F. R. P.; REID, P. Viabilidade econômica de negócios sustentáveis da Biodiversidade em Áreas protegidas: Lições e recomendações. Rio de Janeiro: CSF, 2014.

ALVES, A. M.; MENDONÇA, A. L. de, CALIARI M.; SANTIAGO, R. A. C. Avaliação química e física de componentes do Baru (Dipteryx Alata Vog.) para estudo da vida de prateleira. Pesq. Agropec. Trop., Goiânia, v. 40, n. 3, p. 266-273, 2010.

BALZON, D. R. Avaliação econômica dos produtos florestais não madeiráveis na área de Proteção Ambiental - APA de Guaratuba - Paraná. 2006. 195 p. Tese (Doutorado em engenharia Florestal) - Universidade Federal do Paraná, Curitiba, PR, 2006.

BENTES-GAMA, M. M. Importância dos produtos florestais não madeireiros (PFNM) para a economia regional. Circular técnica, n81, Porto Velho-RO, Dez. 2005. 
BENTO, A. P. N.; COMINETTI, C.; SIMÕES FILHO, A.; NAVES, M. M. V. Baru almond improves lipid profile in mildly hypercholesterolemic subjects: A randomized, controlled, crossover study. Nutrition, Metabolismand Cardiovascular Disease. v. 24, n. 12, p. 1330-1336, 2014.

BISPO, T. W.; J. D. A. S DINIZ. Agroextrativismo no Vale do rio Urucuia-MG: uma análise sobre pluriatividade e multifuncionalidade no Cerrado. Sustentabilidade em Debate - Brasília, v. 5, n. 3, p. 37-55, 2014.

BOTEZELlI, L.; DAVIDE, A. C.; MALAVASI, M. M. Características dos frutos e sementes de quatro procedência de Dipteryx alata Vogel - (baru). Cerne, v. 6, n.1, p.9-18, 2000.

BRASIL. Lei $\mathrm{n}^{\mathrm{o}}$ 10.696, de 02 de julho de 2003. Dispõe sobre a repactuação e o alongamento de dívidas oriundas de operações de crédito rural, e da outras providências. Diário Oficial da República Federativa do Brasil, Brasília, DF, 3 jul. 2003.

Projeto de Conservação e Manejo da Biodiversidade do Bioma Cerrado CMBBC. Relatório de produtos, Brasil, Embrapa, 2005. Disponível em www.cmbbc.embrapa.br.

Ministério do Desenvolvimento Agrário; Ministério do Meio Ambiente; Ministério de Desenvolvimento Social e Combate à Fome Plano Nacional para Promoção dos Produtos da Biodiversidade. Brasília, DF, 2009.

BRUGNARO, R.; BACHA, C. J. C. Análise da Participação da Agropecuária no Pib do Brasil de 1986 a 2004. Estudos econômicos, São Paulo, v.39, n.1, p.127-159, 2009.

CALDERON, R. A. Mercado de Produtos Florestais Não Madeireiros na Amazônia brasileira. 96p. Tese (Doutorado em Ciências Florestais) - Universidade de Brasília, Brasília, DF, 2013.

CARVAlHO, P. E. R. Baru. Colombo: Embrapa Florestas, 2003. 10 p. (Embrapa Florestas. Circular técnica, 83).

COSTA, B. C. Prospecção e viabilidade econômica para o manejo sustentável de Hymenaea spp. 223 f. Dissertação (Mestrado em Ciência Florestal) - Universidade Federal de Viçosa, Viçosa, MG, 2012.

CORRÊA, G. C.; ROCHA, M. R.; NAVES, R. V. Germinação de sementes e emergência de plântulas de baru (Dipteryx alata vog.) nos cerrados do Estado de Goiás. Pesquisa Agropecuária Tropical, Goiânia, v.30, n.2, p.17-23, 2000.

CROITORU, L. Valuing the non-timber forest products in the Mediterranean region. Ecological Economics, v.63, p. 768-775, 2007.

DRUMMOND, J. A. A extração sustentável de produtos florestais na Amazônia brasileira: vantagens, obstáculos e perspectivas. Estudos Sociedade e Agricultura, v. 6, p. 115 137, 1996. 
EMERY, M. R.; PIERCE, A. R. Interrupting the Telos: Locating Subsistence in Contemporary US Forests. Environment \& Planning. v. 37, n. 6, p. 981-993, 2005.

FERNANDES, D. C.; FREITAS, J. B.; CZEDER L. P.; NAVES, M. M. Nutritional composition and protein value of the baru (Dipteryx alata Vog.) almond from the Brazilian Savanna. Journal of the Science of Food and Agriculture. n. 90, p. 1650-1655, 2010.

FERNANDES, D. C.; ALVES, A. M.; CASTRO G. S. F.; JORDÃO, A. A. Effects of Baru Almond and Brazil Nut Against Hyperlipidemia and Oxidative Stress In Vivo. Journal of Food Research. Toronto, v. 4, n. 4, p. 38-46, 2015.

FERREIRA, R.A.; BOTELHO, S.A.; DAVIDE A.C.; MALAVASI M. de M. Caracterização morfológica de fruto, semente, plântula e muda de Dipteryx alata Vogel baru (Leguminosae Papilionoideae). Cerne, v.4, n.1, p.73-87, 1998.

FREITAS, J. B. de. Qualidade nutricional e valor proteico da amêndoa de baru em relação ao amendoim, castanha-de-caju e castanha-do-pará. 57 f. Dissertação (Mestrado em Ciências e Tecnologia de Alimentos) - Universidade Federal de Goiás, Goiânia, GO, 2009.

FIEDLER, N. C.; SOARES, T. S.; SILVA, G. F. da. Produtos Florestais Não Madeireiros: Importância e Manejo Sustentável da Floresta. Revista Ciências Exatas e Naturais, vol. 10 n.2, p.16, 2008.

GRZEBIELUCKAS, G. A Influência dos custos ambientais externos na produção agrícola: estudo comparativo entre frutos do cerrado e pecuária leiteira. $223 \mathrm{f}$. Tese (Doutorado em Engenharia de Produção) - Universidade Federal de Santa Catarina, Florianópolis, SC, 2010.

GODOY, R. A.; LUBOWSKI.; MARKANDYA, A. A method for the economic valuation of non-timber tropical forest products. Economic Botany, v. 47, n.3, p.215-219, 1993.

GODOY, R. A.; BAWA, K. S. The economic value and sustainable harvest of plants and animals from the tropical forest: assumptions, hypotheses, and methods. Economic Botany v. 47, n.3, p. 220-233, 1993.

GONÇALVES, L. G. V.; ANDRADE, F. R.; MARIMON JUNIOR, B. H.; SCHOSSLER, T. R.; LENZA, E. E; MARIMON, B. S.). Biometria de frutos e sementes de mangaba (Hancornia speciosa Gomes) em vegetação natural na região leste de Mato Grosso, Brasil. Revista de Ciências Agrárias, vol. 36, n. 1, p. 31-40. 2013.

GUimARÃES, R. C. A.; FAVARO S. P.; VIANA, A. C. A.; BRAGA NETO, J. A.; NEVES, V. A.; HONER M. R. Study of the proteins in the defatted flour and protein concentrate of baru nuts (Dipteryx alata Vog). Ciência Tecnologia de Alimentos. vol. 32, n.3, p. 464- 70, 2012.

HOMMA, A. K. O. Extrativismo vegetal na Amazônia: limites e oportunidades. Brasília: Embrapa - SPI, 1993. 201p. 
HOMMA, A. K. O. Extrativismo, biodiversidade e biopirataria na Amazônia. Texto para discussão 27. Brasília: Embrapa Informação Tecnológica, 2008.

HOMMA; A. K. O Extrativismo vegetal ou plantio: qual a opção para a Amazônia. Estudos Avançados, São Paulo, v. 26, n.74, p. 167-186, 2012.

HOMMA, A. K. O. Extrativismo vegetal na Amazônia: história, ecologia, economia e domesticação. Brasília: Embrapa, 2014a. 468p.

HOMMA, A. K. O.; MENEZES, A. J. E. A. de; MAUES, M. M. Castanheira-do-pará: os desafios do extrativismo para plantios agrícolas. Boletim do Museu Paraense Emílio Goeldi de Ciências Naturais, Belém, PA, v. 9, n. 2, p. 293-306, 2014 b.

KAR, S. P.; JACOBSON, M. G. NTFP income contribution to household economy and related socio-economic factors: Lessons from Bangladesh. Forest Policy and Economics, v. 14, p. 136-142, 2011.

KLIMAS, C. A.; KAINER, K. A. WADT, L. H. de O. The economic value of sustainable seed and timber harvests of multi-use species: An example using Carapa guianensis. Forest Ecology and Management, v. 268, p. 81-91, 2012.

MAGALHÃES, R. M. A cadeia produtiva da amêndoa do Baru (Dipteryx alata Vog.) no Cerrado: Uma análise da sustentabilidade de sua produção. Ciência Florestal, Santa Maria, v. 24, n. 3, p. 665-676, 2014.

MAKISHI, F.; VEIGA, J. P. C.; ZACARELI, M. A. Impactos Socioambientais dos Produtos Florestais Não-Madeireiros: Estudos de Caso da Amazônia Brasileira. Revista Electrónica de Investigação e Desenvolvimento, nº 4, 2015.

MARSHALL, E., SCHRECKENBERG K., NEWTON A. Commercialization of nontimber forest products: First steps in analyzing the factors influencing success. Int Fores Rev, v. 2; p.128-137, 2003.

MARSHALL, E., SCHRECKENBERG, K., NEWTON, A. C. Commercialization of nontimber forest products: Factors influencing success. UNEP World Conservation Monitoring Center, Cambridge, UK. 2006.

MARTINS B. A.; PIMENTEL, N. M.; MENEZZI, C. H. D.; SCHIMIDT, F.L. Processamento de Baru (Dipteryx alata Vog.) - Estado da Arte. IN: VI ENEDS Campinas, São Paulo, 2009.

MARTINS, B. A. Desenvolvimento tecnológico para o Aprimoramento do processamento de polpa e amêndoa do Baru (Dipteryx alata Vog.). 208 f. Tese (Doutorado em Tecnologia de Alimentos) - Universidade Estadual de Campinas, Campinas, São Paulo, 2010.

MINISTÉRIO DO DESENVOLVIMENTO AGRÁRIO - MDA; MINISTÉRIO DO MEIO AMBIENTE - MMA; MINISTÉRIO DE DESENVOLVIMENTO SOCIAL E COMBATE À FOME - MDS. Plano nacional de promoção de cadeias de produtos da sociobiodiversidade. Plano de ação 2009. Brasília: MDA, MMA, MDS, Conab, 2009. 
MENDES, J. T. G.; PADILHA JUNIOR, J. B. Agronegócio: uma abordagem econômica. São Paulo, Pearson Prentice Hall, 2007.

MENEZES, R. S. de. A importância da reserva legal na geração de renda de pequenos produtores rurais: estudo de caso no estado do Acre, Amazônia. Dissertação (Mestrado em Ciências Florestais) - Universidade Federal do Paraná, Curitiba, Paraná, 105 f. 2004.

MITTERMEIER, R. A.; GIL, P. R.; HOFMANN, M.; PILGRIM, J.; BROOKS, T.; LAMOREUX, J.; FONSECA, G. A. B. Hotspost revited. Mexico City: Cemex, 2004.

MORAES, M. A. SILVA, E. C. B.; KUBOTA, T. Y. K.; PUPIN, S.; ZARUMA, D. U. G.; SILVA, A. M.; MORAES, M. L. T. Genetic variability in progenies Dipteryx alata Vog. coming in three states of Brazil. IN: FOREST GENETICS 2013, Whistler, British Columbia, Canada. p. 52-53, 2013.

SILVA JÚNIOR, M. C. da. 100 árvores do cerrado: guia de campo. Brasília, DF: Rede de Sementes do Cerrado, 2005. 278 p.

SILVA, A. M.; MORAES, M. L. T. Genetic variability in progenies Dipteryx alata Vog. coming in three states of Brazil. IN: FOREST GENETICS 2013, Whistler, British Columbia, Canada. p. 52-53, 2013.

MYERS, N. Biodiversity hotspots revisited. Bioscience, v. 53, no. 10, p. 916-917, 2003.

NEUMANN, R. P.; HIRSCH, E. Commercialisation of non-timber forest products: review and analysis of research. Bogor, Indonesia: Center for International Forestry Research, Food and Agriculture Organization of the United Nations (FAO), 2000.

NOGUEIRA, M; FLEISCHER, S. Entre tradição e modernidade: potenciais e contradições da cadeia produtiva agroextrativista no Cerrado. Estudos Sociedade e Agricultura, v. 13, n. 1, p. 125-157, 2005.

NOGUEIRA, J. M.; JÚNIOR, A. N.; BASTOS, L. Empreendimentos extrativistas como alternativas para geração de renda: do sonho ambientalista à realidade do estudo de mercado. Rev. Ciênc. Admin, v. 15, n. 1, p. 85-104, 2009.

OLIVEIRA, A. N. Variações genéticas entre e dentro de procedências de baru (Dipteryx alata Vog.). 81 p. Dissertação (Mestrado em Ciências Florestais) -Universidade Federal de Lavras, Lavras, Minas Gerais, 1998.

OLIVEIRA, M. I. B.; SIGRIST, R. Fenologia reprodutiva, polinização e reprodução de Dipteryx alata Vogel ( Leguminosae-Papilionoideae ) em Mato Grosso do Sul , Brasil. Revista Brasileira de Botânica, v. 31, n. 2, p. 195-207, 2008.

PASTORE, J. F.; BORGES, V. L; Produtos Florestais Não-Madeireiros Processamento, Coleta e Comercialização. Projeto ITTO PD 143/91. LATEQ - IQ UnB, Brasília, 1998. 54p. 
PAUlA, M. M., KAMIMURA, Q. P., SILVA, J. L. G. Mercados institucionais na agricultura familiar: Dificuldades e desafios. Revista de Política agrícola, Taubaté, v. 23, $\mathrm{n}^{0} 1$, p. 33-43, 2014.

PETERS, C.M., GENTRY, A.H. AND MENDELSOHN, R.O. 1989 Valuation of na Amazonian rainforest. Nature, v.339, p. 655-656, 1989.

PIMENTEL, N. M.; DEL MENEZZI, C. H.; GONÇALEZ, J. Aproveitamento dos Produtos Florestais Não Madeireiros do Baru (Dipteryx alata Vog,). In: BENSUSAN, N. Unindo Sonhos: pesquisas ecossociais no cerrado. Brasília, Instituto Internacional de Educação no Brasil, p. 269-293. 2009.

PRIMACK, R. B.; E. RODRIGUES. Biologia da Conservação. Londrina - PR: Editora Planta, 2001. 328 p.

RATTER, J. A.; BRIDGWATER, S.; RIBEIRO, J. F.; DIAS, T. A. B.; SILVA, M. R. Estudo preliminar da distribuição das espécies lenhosas da fitofisionomia Cerrado sentido restrito nos Estados compreendidos pelo Bioma Cerrado. Boletim do Herbário Esechias Paulo Heringer, Brasília, v.5, p.5-43, 2000.

RÊGO, J. F. do. Amazônia: do extrativismo ao neoextrativismo. Ciência Hoje, Rio de Janeiro, v. 25, n. 147, p. 62-65, 1992.

RÊGO, L. J. S. Análise econômica da produção da amêndoa de cumaru e caracterização do seu mercado em Santarém e Alenquer, Pará. Dissertação (Mestrado em Ciências Florestais) - Departamento de Engenharia Florestal, Universidade Federal de Viçosa, Viçosa, Minas Gerais, 116 p., 2014.

RIBEIRO, J. F.; WALTER, B. M. T. As principais fitofisionomias do bioma cerrado. In: SANO, S. M.; ALMEIDA, S. P.; RIBEIRO, J. F. (Ed.). Cerrado: ecologia e flora, DF: Embrapa Informação Tecnológica, Brasília, 2008. p. 151-212.

RIZEK, M. B.; MORSELLO, C. Impacts of Trade in Non-timber Forest Products on Cooperation among Caboclo Households of the Brazilian Amazon. Human Ecology, Vol.40(5), p.707-719, 2012.

ROCHA, L.S.; SANTIAGO R. A. C. Implicações nutricionais e sensoriais da polpa e casca de baru (Dipteryx alata Vog.) na elaboração de pães. Ciência Tecnologia de Alimentos, Campinas, v. 29, n.4, p.820-825, 2009.

SANTOS, A. J. dos; HILDEBRAND, E.; PACHECO, C. H. P.; PIRES, P. T. de L.; ROCHADELLI, R. Produtos não madeireiros: conceituação, classificação, valoração e mercados. Floresta, Curitiba, v.2, n. 33, p. 215- 224, 2003.

SANTOS, A. J. dos; GUERRA, F. G. P. de Q. Aspectos Econômicos da Cadeia Produtiva dos Óleos de Andiroba (Carapa Guianensis Aubl.) e Copaíba (Copaifera Multijuga Hayne) na Floresta Nacional Do Tapajós - Pará. Floresta, Curitiba, v. 40, n. 1, p. 23-28, 2010.

SANTOS, G. G.; SILVA, M. R.; LACERDA, D. B. C. L.; MARTINS, D. M. O. M.; ALMEIDA, R. A. A. Aceitabilidade e Qualidade Físico-Química de Paçocas Elaboradas 
com Amêndoa de Baru. Pesquisa Agropecuária Tropical, Goiânia, v. 42, n. 2, p. 159$165,2012$.

SANO, S. M.; BRITO, M. A.; RIBEIRO, J. F. Baru. In: VIEIRA, R. F.; AGOSTINICOSTA, T. S., SILVA, D. B.; SANO, S.; FERREIRA, F. R. Frutas nativas da região centro-oeste. Brasília: Embrapa, p. 83-107, 2010.

SANO, S. M.; RIBEIRO, J. F.; BRITO, M. A. de. Baru: biologia e uso. Planaltina, DF: Embrapa Cerrados, 52p, 2004.

SCHAAFSMA, M.; MORSE-JONES, P.; POSEN, P.; SWETNAM, R. D.; BALMFORD, A.; BATEMAN, I. J.; BURGESS, N. D.; CHAMSHAMA, S. A. O.; FISHER, B.; GREEN, R. E.; HEPELWA, A. S.; HERNÁNDEZ-SIRVENT, A.; KAJEMBE, G. C.; KULINDWA, K.; LUND, J. F.; MBWAMBO, L.; MEILBY, H.; NGAGA, Y. M.; THEILADE, I.; TREUE, T.; VYAMANA, V. G.; TURNER, R.K. Towards transferable functions for extraction of Non-timber Forest Products: A case study on charcoal production in Tanzania. Ecological Economics, v.80, p. 48-62, 2012.

SHACKLETON, S,. SHANLEY, P., NDOYE, O. Invisible but viable: recognising local markets for nontimber forest products. International Forestry Review, vol.9, n.3, p. 697$712,2007$.

SHANLEY, P.; PIERC, A.; LAIRD, S. Além da madeira: a certificação de produtos florestais não madeireiros. Belém: Centro Internacional para Pesquisa Florestal, 155 p. 2006.

SILVA, F.C.T. Conquista e colonização da América Portuguesa: o Brasil Colônia 1500/1750. In: LINHARES, M.Y. (Org.). História geral do Brasil: da colonização portuguesa à modernização autoritária. Rio de Janeiro: Campus, 1990. p. 33-94.

SILVA, A. M. da., VALENTE, E. F. Bioma Cerrado e desenvolvimento sustentável: as atividades extrativistas como alternativas de trabalho e renda. SOBER, Londrina, 2007.

SILVA, P.S. Análise econômica e socioambiental da produção extrativista de frutos de cerrado: O caso da Cooperfruto, Tocantins. Dissertação (Mestrado em Desenvolvimento Regional e Agronegócio) - Universidade Federal do Tocantins, Palmas, Tocantins, 148 p., 2011.

SILVA-JÚNIOR, M. C.; SANTOS, G. C.; NOGUEIRA, P. E.; MUNHOZ, C. B. R.; RAMOS, A.E. 100 árvores do Cerrado: guia de campo Brasília: Editora Rede de Sementes do Cerrado. 2 ed, 2012, 278p.

SIQUEIRA E. M. de A.; MARIN, A. M. F.; CUNHA M. S. B. da.; FUSTINONI, A. M.; SANT'ANA, L. P. de.; ARRUDA S. F. Consumption of baru seeds [Dipteryx alata Vog.], a Brazilian savanna nut, prevents iron-induced oxidative stress in rats. Food Research International, Toronto, v. 45, p. 427-433, 2012.

SIQUEIRA, A. P. S.; PACHECO, M. T. B.; NAVES, M. V. Nutritional quality and bioactive compoundsof partially defatted baru almond flour. Food Science and Technology, Campinas, v. 35, n.1, p. 127-132, 2015. 
STRIDSBERG, I. H. C. Produção agroflorestal sustentável: Estudo de caso em pequenas propriedades no litoral paranaense. 2001. 132 p. Tese (Doutorado em Engenharia Florestal) - Universidade Federal do Paraná, Curitiba, Paraná, 2001.

VERA, R.; SOARES, M. S.; NAVES, R. V.; SOUZA, E. R. B. de.; FERNANDES, E. P.; CALIARI, M.; LEANDRO, W. M. Características químicas de amêndoas de baruzeiros (Dipteryx alata Vog.) de ocorrência natural no cerrado do estado do Goias, Brasil. Revista Brasileira de Fruticultura, v.31, n.1, p.112-118, 2009.

VIEIRA, R. F.; COSTA, T. S. A.; SILVA. D. B.; FERREORA, F. R. SANO, S. M. Frutas nativas da região Centro-Oeste do Brasil. Brasília: Embrapa Recursos Genéticos e Biotecnologia, 2006.

ZAIDAN, L. B. P.; CARRERA, R. C. Seed germination in Cerrado species Brazilian. Journal of Plant Physiology, v. 20, n. 3, p. 167-181, 2008.

ZAMORA, M. Analise de la informacion sobre produtos florestales no madereros em América Latina. San Tiago: FAO, 2001. 88 p. 


\section{CAPÍTULO 1}

\section{VIABILIDADE FINANCEIRA DO EXTRATIVISMO DO BARU (Dipteryx alata VOGEL)}

\section{RESUMO}

O baru é uma espécie de grande potencial madeireiro e não madeireiro. Suas sementes são comercializadas devido ao seu grande potencial nutricional. A produção das castanhas é realizada por agroextrativistas, gerando renda para famílias vulneráveis socialmente. O objetivo deste capítulo é realizar um estudo da viabilidade econômica e financeira, com uso de diferentes indicadores econômicos de rentabilidade e avaliação econômica com indicadores que consideram a variação do valor do capital no tempo. Foram avaliadas as safras de 2013 e 2014, consideradas de alta e baixa produção, respectivamente. Foram estudados diferentes perfis de extrativistas, principalmente dos agroextrativistas médios, os mais produtivos e a organização coletiva dos agroextrativistas, resultante da união dos agroextrativistas que produzem acima da média na região mais produtiva. $\mathrm{O}$ extrativismo se mostrou viável financeiramente em todos os indicadores de rentabilidade, com exceção da receita líquida dos agroextrativistas médios da safra de 2014, que ficou negativo. O fator preponderante foi o aumento no valor da mão de obra. Ao analisar a viabilidade da atividade na perspectiva da execução de um investimento, o extrativismo se mostrou viável somente para o coletivo de agricultores. O investimento somente ficará viável caso os agroextrativistas individuais reduzam a quantidade de mão de obra em patamares acima de $10 \%$.

Palavras-chave: Indicadores econômicos, rentabilidade, valor presente líquido 


\title{
CHAPTER 1
}

\section{ECONOMIC VIABILITY OF THE BARU EXTRACTIVISM (Dipteryx alata Vogel)}

\begin{abstract}
Baru is a great timber and non-timber potential species. Its seeds are traded for its great food and nutritional potential. The Baru nuts production is undertaken by agroextractivist farmers, generating income for socially vulnerable families. The objective of this chapter is to perform an economic feasibility study by using different economic indicators as well as an economic evaluation with indicators that consider the capital value variation in time. The 2013 and 2014 harvests were evaluated, which were considered of high and low production respectivelly.Different profiles of extractivist farmers were also considered, specially the medium agroextrativist producers, the most productiveones and the simulation of an association of the agroextrativists who produce above average in the most productive area. Extractivism has shown to be economically feasible for all profitability indicators with exception of the net income of the less productive farmers in the harvest of 2014, where it remained slightly negative, having as its major contributing factor the increase of labor costs. By analyzing the feasibility of the activity under the perspective of the implementation of an investment, extractivism has shown to be feasible only for an association. The investment would only turn feasible if the individual agroextractivists reduced labor costs to over $10 \%$.
\end{abstract}

Key words: Economic indicators, profitability, net present value 


\section{1 - INTRODUÇÃO}

Estudos sobre a economia extrativista, que analisam a importância na renda dos agricultores familiares do Cerrado, assim como a sua viabilidade econômica, são escassos. A oferta de PFNMs de espécies nativas do Cerrado é basicamente extrativista e sofre críticas quanto a sua sustentabilidade.

A atividade extrativista economicamente viável, sustentável sócio e ambientalmente, configurará como outro modelo de exploração das áreas de cerrado, que não a defloração e a substituição vegetal, tornando mais uma opção para agregar valor econômico à exploração da propriedade (SILVA, 2011).

Desta forma, a avaliação da viabilidade econômica do uso dos PFNMs torna-se de suma importância para subsidiar os tomadores de decisão na formulação de políticas públicas de valorização e estímulo na comercialização desses produtos (NOGUEIRA; FLEISCHER, 2005; BONFIM, 2010).

A viabilidade depende claramente de uma análise completa e de uma compreensão dos custos de produção, que incluem não só a coleta, e transporte, mas também muitos outros custos. As despesas precisam ser cuidadosamente enumeradas, quantificadas e descritas ao longo do tempo (NEUMANN; HIRSCH, 2000).

São várias as considerações que devem ser feitas na análise de viabilidade econômica. A localização das áreas de distribuição e os centros de apoio e comercialização é umas delas, pois incidem diretamente na competitividade do produto devido aos altos custos de transporte e aos problemas de embalagem do produto. Outro requisito importante para que um PFNM seja competitivo é a disponibilidade de um fluxo constante de volume de produção, que, ademais, mantenha sempre uma qualidade homogênea (FIEDLER et al., 2008).

A cadeia produtiva do baru aponta distintos pontos de ordem tecnológica com potencial de serem melhorados e estudados, otimizando processos e agregando valor aos subprodutos, levando assim a um aproveitamento integral do fruto, reduzindo o impacto no ambiente e 
aumentando a produtividade e lucratividade das empresas de uma forma sustentável (MARTINS, 2009).

Analisando o comércio do baru, Magalhaes (2014) observou uma relação comercial fragmentada entre os agroextrativistas do baru e compradores da amêndoa. Os principais fatores relacionados foram à irregularidade no fornecimento do produto, que pode ocorrer em decorrência de fatores tais como: a sazonalidade da frutificação, irregularidade nas quantidades produzidas pelas árvores.

Frente a esta situação questiona-se: existe a possibilidade das referidas atividades serem sustentáveis e viáveis economicamente? E os custos de oportunidade envolvidos? E os benefícios para as gerações futuras e o equilíbrio ecológico, como podem ser atribuídos as escolhas que se dão no presente? (SILVA, 2011)

\section{2 - OBJETIVOS}

\section{1 - OBJETIVO GERAL}

- Analisar a viabilidade econômica e financeira da atividade extrativa do baru.

\section{2 - OBJETIVOS ESPECÍFICOS}

- Estudar o efeito da sazonalidade e volatilidade na renda das famílias envolvidas;

- Realizar uma análise da rentabilidade e viabilidade financeira do extrativismo;

- Analisar o efeito do aumento da escala de produção na viabilidade econômica e financeira.

\section{3 - MATERIAIS E MÉTODOS}

\section{1 - CARACTERIZAÇÃO DA ÁREA DE ESTUDO}

A área de estudo compreende o município de Arinos, estado de Minas Gerais, situado na mesorregião do Noroeste, microrregião de Unaí, fazendo parte do Território da Cidadania 
Vale do Urucuia. Possui coordenadas geográficas $-15^{0} 54^{\prime} 12,63$ ” S e $-46^{0} 05$ ' 46,35" W e altitude média de $520 \mathrm{~m}$, o clima é classificado como Aw, de acordo com a classificação de Köppen e Geiger, a temperatura média anual em Arinos é de $23.9{ }^{\circ} \mathrm{C}$ e a precipitação média anual de $1.181 \mathrm{~mm}$.

De acordo com os dados disponibilizados pelo sistema on-line do inventário florestal da flora nativa e dos reflorestamentos de Minas Gerais, o município de Arinos possui uma cobertura vegetal de 58,85\% do seu território (UFLA, 2009). Informações disponibilizadas pelo último censo agropecuário demonstram que, $75,51 \%$ dos estabelecimentos rurais da área de estudo são enquadrados como áreas de agricultura familiar (IBGE, 2006).

O município de Arinos possui um Índice de Desenvolvimento Humano Municipal (IDHM) de 0,656 (PNUD, 2014). No estado de Minas Gerais 69,28\% municípios estão em situação melhor e 30,72\% municípios estão em pior situação no desenvolvimento humano (PNUD, 2014).

Os resultados do Zoneamento Ecológico Econômico indicam o município de Arinos como Prioridade de Conservação Alta e Muito Alta, possuindo alta vulnerabilidade ambiental e baixa potencialidade social, a região é enquadrada nos piores índices ecológicos e econômicos do Estado de Minas Gerais, indicando fragilidade ambiental e desenvolvimento social insuficiente (SCOLFORO et al., 2008).

Para analisar o efeito da sazonalidade nos preços e o efeito da volatilidade na produção, a área de estudo foi dividida em regiões, o critério utilizado, foi à ocorrência de populações naturais de baruzeiros e agroextrativistas que comercializam seus frutos.

Foram observadas 5 regiões produtivas, classificadas como Região Chico Mendes (Região I), Rancharia (Região II), Sagarana (Região III), Igrejinha (Região IV) e Santiago (Região V). Na região Chico Mendes, localizam-se os Projetos de Assentamento Chico Mendes, P.A Carro Quebrado e Fazenda Roça, na Região Rancharia (II), localizam-se os P.A Rancharia, P.A Santa Terezinha, P.A Borá e Fazenda Pedrinhas.

\section{2 - COLETA E ANÁLISE DOS DADOS}


Para a coleta de dados foram utilizados questionários aplicados por meio de entrevistas semiestruturadas, que consiste numa técnica de pesquisa que combina perguntas abertas e fechadas, em que o informante tem a possibilidade de discorrer sobre o tema proposto. $\mathrm{O}$ pesquisador deve seguir um conjunto de questões previamente definidas, mas ele o faz em um contexto muito semelhante ao de uma conversa informal (QUARESMA e BONI, 2005). O questionário, previamente elaborado, teve a finalidade de coletar dados socioeconômicos das famílias extrativistas, dados físicos e econômicos de suas atividades, estimando os custos e as receitas da atividade extrativista.

Todos os rendimentos operacionais, receitas e despesas foram apurados a partir dos resultados das entrevistas. A pesquisa foi realizada nos meses de maio e agosto de $2015 \mathrm{e}$ as informações e análises realizadas são referentes a duas safras consecutivas: anos agrícolas 2013/2014 e 2014/2015.

Para a tabulação dos dados foram utilizadas planilhas eletrônicas, sistematizando as informações obtidas nas entrevistas, gerando gráficos, tabelas e outras informações relevantes para as análises sócio econômicas.

\subsection{1 - Base estatística}

O delineamento da pesquisa foi do tipo levantamento de campo, essa técnica de pesquisa se caracteriza pela interrogação direta das pessoas cujo comportamento se deseja conhecer. Basicamente, procede-se à solicitação de informações a um grupo significativo de pessoas acerca do problema estudado para em seguida, mediante análise quantitativa, obter as conclusões correspondentes dos dados coletados (GIL, 2008).

Foi utilizada a estatística descritiva para análise dos dados, utilizando-se de gráficos, tabelas e medidas de síntese como porcentagens, índices e médias para analisar os resultados (BITTENCOURT, 2012). Para quantificar o tamanho da população, buscou-se atender o nível de $95 \%$ de confiança, a suficiência amostral (n) foi calculada com base nos cálculos aplicados por Gil (2008), como apresentado na fórmula:

A fórmula para o cálculo do tamanho da amostra (n) é: 


$$
\mathrm{n}=\frac{\sigma^{2} \cdot \mathrm{p} \cdot \mathrm{q} \cdot \mathrm{N}}{e^{2}(\mathrm{~N}-1)+\sigma^{2} \cdot \mathrm{p} \cdot \mathrm{q}}
$$

Onde:

$\mathrm{n}=$ Tamanho da amostra

$\sigma^{2}=$ Nível de confiança escolhido, expresso em número de desvios-padrão

$\mathrm{p}=$ Percentagem com a qual o fenômeno se verifica

q= Tamanho da população a ser estudada

$\mathrm{N}=$ tamanho da população

$e^{2}=$ erro admissível

Os entrevistados foram selecionados por amostragem não probabilística, pela técnica 'bola de neve' (ALBUQUERQUE et al., 2010). Essa técnica é uma forma de amostra em que os participantes iniciais de um estudo indicam novos participantes do universo a ser estudado, os quais, por sua vez, indicam novos participantes e, assim sucessivamente, até que seja alcançado o objetivo proposto (SILVA et al., 2013). Essa técnica é utilizada para estudos de populações raras ou desconhecidas, que não possuem lista de seus membros (SALGANIK e HECKARTHORN, 2004).

Para estudo da produção das regiões selecionadas, adotou-se o delineamento inteiramente casualizado, com 4 tratamentos. Para auxiliar a análise estatística foi utilizado o programa Sistema de Análise de Variância/SISVAR (FERREIRA, 1999). As médias foram comparadas pelo teste de Tukey a $5 \%$ de probabilidade de erro.

As diferentes regiões produtivas foram consideradas como tratamentos, sendo comparadas em função das variáveis: volume de comercialização e preço da castanha, na safra e entressafra.

A análise dos preços em relação a safra é necessária, pois ocorre uma grande variação na produção, afetando diretamente a oferta dos frutos, consequentemente o comportamento dos preços.

\subsection{2 - Estrutura das Receitas}


Para a definição das receitas foi analisado o volume da produção e os preços médios praticados nos períodos de safra e entressafra. Posteriormente foi elaborado um fluxo de caixa simulando a produção de baru no período de 10 anos, esse fluxo foi construído usando os valores da produção regional.

A volatilidade da produção foi simulada utilizando as informações de Sano e Simon (2008), que monitorando as frequências de classes de produção de frutos em árvores marcadas de baru, observou anos de baixa produção de frutos como 1997, 1999 e 2002, e anos com alta produção de frutos, 1994, 1995 e 1998.

Essa volatilidade da produção do baru e seu efeito nos preços foram reproduzidos para o período de 2005 a 2014. Assim, todas as receitas e os custos desse horizonte de planejamento foram deflacionados, corrigidos pela variação anual do Índice Geral de Preços- Disponibilidade Interna (IGP-DI) (anexo III).

A safra é compreendida entre o período de agosto do ano anterior até fevereiro do ano subsequente, ao se afirmar que estamos analisando a safra de 2013, na verdade o período avaliado corresponde a 15 de agosto de 2013 a 15 de fevereiro de 2014, período compreendido entre o início da coleta a comercialização final da produção, e o período de análise da safra de 2014, compreende 15 de agosto de 2014 a 15 de fevereiro de 2015.

\subsection{3 - Estrutura de custos}

O custo total de produção pode ser definido como o total das despesas realizadas com a combinação mais econômica dos fatores, por meio da qual é obtida determinada quantidade do produto (VASCONCELOS e GARCIA, 2014). Nesse estudo os custos foram divididos em fixos e variáveis, conforme metodologia da Companhia Nacional de Abastecimento para estimar custos de produção agrícola (CONAB, 2010).

Os custos fixos incluem todas as formas de remuneração ou ônus decorrentes da manutenção dos recursos, portanto, esses custos existem mesmo que a empresa não esteja produzindo. Entre esses custos pode-se citar a depreciação de benfeitorias e juros sobre o capital investido (MENDES, 1989). 
Os custos variáveis decorrem de todos os pagamentos dirigidos aos serviços executados e/ou aos materiais utilizados que variam diretamente com a produção (MENDES, 1989).

A determinação precisa dos custos é fundamental para uma avaliação correta da atividade extrativista. O custo da atividade foi determinado estimando o tempo médio de coleta, beneficiamento, transporte e demais atividades do agroextrativismo do baru, calculando em homens dias de trabalho.

Para determinar os custos variáveis, foram consideradas as despesas com materiais e serviços utilizados. A mão de obra empregada na coleta e beneficiamento dos frutos, assim como despesas com o transporte externo da produção, foi inserida nos custos. Outros custos avaliados foram manutenção da carroça e do veículo, gastos com alimentação animal e com combustível. O custo de oportunidade utilizado nesse estudo foi o preço da mão de obra rural não especializada.

Entre os principais custos fixos avaliados, destacam-se a depreciação de máquinas e benfeitorias. Foram depreciados o paiol, residência, máquinas e implementos, como o carro e a carroça, assim como a foice artesanal adaptada. Outro custo fixo avaliado foi a remuneração do capital fixo investido na construção do paiol. Os valores dos custos fixos foram calculados, considerando somente o tempo que os fatores de produção foram dedicados à atividade. Nesse estudo considerou-se que agroextrativistas desempenham outras atividades produtivas, e suas máquinas e implementos são utilizados em diversas outras atividades produtivas.

Para o cálculo da depreciação de máquinas e implementos, adotaram-se a metodologia da Conab (2010), onde:

$$
\mathrm{DM}=[(\mathrm{VN}-\mathrm{VR}) / \mathrm{VUH}] \times \mathrm{HsTR}
$$

Onde:

$\mathrm{DM}=$ Depreciação de máquinas e implementos

$\mathrm{VN}=$ Valor do bem novo

$\mathrm{VR}=$ Valor residual do bem

VUH = Vida útil definida em horas 
HsTR $=$ Total de horas trabalhadas

Para o cálculo da depreciação de benfeitorias, utiliza-se a seguinte fórmula:

$$
\mathrm{DB}=\{[(\mathrm{VN}-\mathrm{VR}) / \mathrm{VUA}] \times \text { Tocup }\} / \text { Área }
$$

Onde:

$\mathrm{DB}=$ Depreciação de benfeitorias

$\mathrm{VN}=$ Valor do bem novo

$\mathrm{VR}=$ Valor residual do bem

VUA = Vida útil do bem, definida em anos

Tocup = Taxa de ocupação do bem, definida como sendo o percentual de utilização deste bem em uma determinada atividade.

\subsection{4 - Fluxo de Caixa}

A análise da viabilidade econômica foi executada construindo fluxos de caixa, que serviram para o cálculo dos indicadores econômicos. Fluxo de caixa consiste no ordenamento temporal de entradas e saídas de valores monetários ao longo do ciclo de vida do empreendimento (BOMFIM, 2010).

Para construção do fluxo de caixa, foi estimada a produtividade do baru ao longo de 10 anos de horizonte de planejamento (figura 2), todos os preços apurados foram deflacionados utilizando o IGP-DI e foram descontados a uma taxa mínima de atratividade de 3,5\% a.a. Esse valor é referente aos valores adotados no financiamento de implantação de áreas de fruticultura do Programa Nacional de Fortalecimento da Agricultura Familiar (Pronaf/fruticultura).

Os valores utilizados para a construção do fluxo de caixa são referentes ao ano de 2014. Todos os valores dos diferentes perfis de agroextrativista foram deflacionados para o horizonte em análise. Os valores determinados para os itens dos custos fixos e variáveis foram deflacionados utilizando o aplicativo EasyCalc- Cálculos financeiros e judiciais pela web, esse aplicativo é disponibilizado na rede mundial de computadores e permite calcular 
atualizações de valores utilizando os principais índices econômicos e financeiros (EASYCALC, 2016).

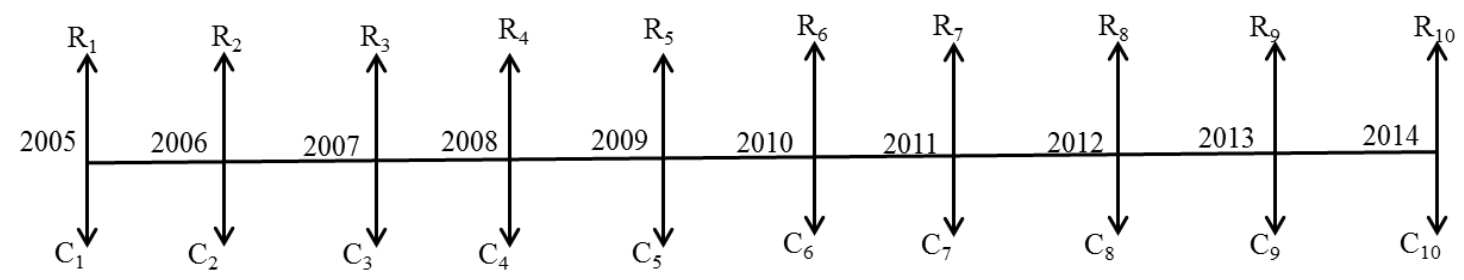

Figura 2 - Diagrama do fluxo de caixa no período de tempo adotado.

\section{3 - ANÁLISE ECONÔMICA E FINANCEIRA E MÉTODOS UTILIZADOS}

A análise econômica foi realizada prevendo cenários distintos, sendo eles, os agroextrativistas médios, os mais produtivos e uma organização coletiva de agroextrativistas. O coletivo de agroextrativistas proposto consiste na reunião dos 7 agroextrativista mais produtivos da Região de Sagarana. Para criar o cenário dos agroextrativistas mais produtivos foram selecionados todos os entrevistados que produziram acima das médias, totalizando 14 agroextrativistas.

Todos os preços empregados na análise econômica, como produtos, materiais, equipamentos e/ou serviços, foram coletados na própria região, refletindo o real potencial econômico das alternativas testadas. Observa-se, ainda, que esse modelo investiga os custos executados, ou seja, a apropriação dos valores gastos no processo de produção depois que o produto já foi gerado, por isso ex-post. Diferentemente de uma análise exante, onde se trabalha com custos planejados ou projetados (CASTELO, 2000).

Para realizar a análise dos aspectos econômicos e os métodos utilizados, os indicadores foram diferenciados entre os métodos que avaliam a rentabilidade e os métodos de análise financeira. Para comparar os indicadores econômicos de rentabilidade nas diferentes safras, os resultados da safra de 2013, foram corrigidos para o ano de 2014. Para a análise financeira todos os preços foram deflacionados para o horizonte de planejamento selecionado, descontando o efeito da inflação.

Os indicadores de rentabilidade utilizados foi a receita líquida (RL), a renda do trabalho familiar (RTF) e a remuneração da mão-de-obra familiar (RMOF). Esse último tem o 
objetivo de analisar se o trabalho desenvolvido está pagando seu custo de oportunidade, conforme metodologia adotada por Santos et al. (1999), Sá et al. (2008), Silva et al., (2013) e Rêgo (2014).

Para a análise financeira, utilizou-se como indicadores de resultado econômico, o valor presente líquido (VPL), o benefício periódico equivalente (BPE) e o custo médio de produção (CMPr), que têm, como vantagem, o fato de considerarem o efeito da dimensão tempo na variação do capital.

Os custos fixos e variáveis foram deflacionados os valores do período de julho de 2005 a julho de $2014($ Base= jul/2014). O mês de julho foi selecionado como referência, pois geralmente, nesse mês todas as castanhas já foram comercializadas, portanto todas as flutuações de preço da safra anterior já ocorreram. O indicador utilizado foi o Índice Geral de Preços- Disponibilidade Interna (IGP-DI), publicado pela Fundação Getúlio Vargas (2014) (anexo III).

\subsection{1 - Valor Presente Líquido (VPL)}

A viabilidade econômica de um projeto analisada pelo VPL é indicada pela diferença positiva entre receitas e custos atualizados para uma determinada taxa de desconto. O VPL tem o objetivo de avaliar propostas de investimento de capital, reflete a riqueza em valor monetário de investimento medida pela diferença entre o valor presente das entradas e saídas de caixa, a uma determinada taxa de desconto (RESENDE e OLIVEIRA, 2013).

A fórmula para o cálculo do Valor Presente Líquido (VPL) é:

Em que:

$$
V P L=\sum \underset{\mathrm{J}=0}{R_{j}^{\mathrm{n}}}(1+i)^{-j}-\sum \underset{\mathrm{J}=0}{C_{j}^{\mathrm{n}}}(1+i)^{-j}
$$

$\mathrm{Cj}=$ custos no final do período de tempo considerado;

$\mathrm{Rj}=$ receita no final do período de tempo considerado;

$\mathrm{i}=$ taxa de juros;

$\mathrm{j}=$ período em que as receitas ou os custos ocorrem; e

$\mathrm{n}=$ duração do projeto em anos. 
Para analisar a capacidade de pagamento dos agroextrativistas de projetos de investimentos individuais e/ou coletivos, foi previsto a construção de um paiol no valor de R $\$ 2.100,00$, ponderado no estudo de Leite et al. (2014). Esse valor foi depreciado e deflacionado para o período do fluxo de caixa.

Foram simulados cenários de mudança nas quantidades de mão de obra e no valor da mesma, esses cenários foram avaliados para os agroextrativistas médios, mais produtivo e pelo coletivo dos agroextrativistas.

\subsection{2 - Benefício Periódico Equivalente (BPE)}

Esse método visa transformar o valor atual do projeto, ou o seu VPL, em um fluxo de receitas ou custos anuais e contínuos, equivalente ao valor atual, durante a vida útil do projeto (SILVA et al., 2008). É a parcela periódica e constante necessária ao pagamento de uma quantia igual ao VPL da opção de investimento em análise ao longo de sua vida útil (REZENDE e OLIVEIRA, 2013).

A fórmula para o cálculo do Benefício Periódico Equivalente (BPE) é:

$$
B P E=\frac{\left.V P L /(1+i)^{t}-1\right](1+i)^{n t}}{(1+i)^{n t}-1}
$$

Onde:

VPL= Valor presente líquido;

$\mathrm{i}=$ taxa de desconto;

$\mathrm{n}=$ duração do projeto (em anos); e

$\mathrm{t}$ = número de períodos de capitalização.

Se caso o $\mathrm{t}=1$, então teremos:

$$
B P E=\frac{V P L \cdot i \cdot(1+i)^{n}}{(1+i)^{n}-1}
$$




\subsection{3 - Custo Médio de Produção (CMPr)}

Para a análise da viabilidade econômica do extrativismo a definição dos custos de produção é determinante. O CMPr consiste em dividir o valor atual do custo total pela produção total equivalente. A produção equivalente é a quantidade produzida descontada ou atualizada pela taxa de juros. Ele indica o ponto onde se opera a um custo mínimo de produção. Se estiver abaixo do preço do produto no mercado, o projeto será viável (SILVA et al., 2008).

A fórmula para o cálculo do Custo Médio de Produção (CMPr) é:

$$
C M P r=\frac{\sum_{j=0}^{n} C T_{J}(1+i)^{-j}}{\sum_{j=0}^{n} P T_{J}(1+i)^{-j}}
$$

Onde:

$\mathrm{CT}_{j}=$ custo total atualizado em cada período, $\mathrm{R} \$ . \mathrm{safra}^{-1} ; \mathrm{e}$

$\mathrm{PT}_{j}=$ produção total equivalente em cada período, kg.safra ${ }^{-1}$.

\subsection{4 - Remuneração da mão de obra familiar (RMOF)}

Determinar a remuneração da mão de obra familiar é essencial para fazer uma comparação direta entre a remuneração que o agricultor pode obter com a venda de sua mão de obra (seu custo de oportunidade) e o que pode ganhar em sua propriedade. Representa o valor máximo da diária que a atividade extrativista pode pagar aos membros da família (SÁ et al., 2008; SILVA et al. 2013; RÊGO, 2014).

Se o valor da RMOF for superior ao valor pago pela diária nos serviços de extração do baru, significa que compensa os membros da família trabalhar na sua propriedade, porém quando a remuneração dos membros da família não compete com este valor, pode indicar uma propensão dos mesmos a buscar alternativas de trabalhos em outras atividades com melhores remunerações. 
A RMOF foi estimada de acordo com Sá et al., (2000):

$$
R M O F=\frac{R T F}{H / D F}
$$

Onde:

$\mathrm{RMOF}=$ remuneração da mão de obra familiar, $\mathrm{R} \$ . \mathrm{safra}^{-1}$;

$\mathrm{RTF}=$ renda do trabalho familiar, $\mathrm{R} \$ . \mathrm{safra}^{-1} ; \mathrm{e}$

H/DF = número diárias de mão de obra familiar das atividades do extrativismo, dias/homem de trabalho $(\mathrm{h} / \mathrm{d})$.

O cálculo da RTF é resultante da subtração da renda bruta de todas as despesas, exceto as da mão de obra familiar, sendo que a receita líquida obtida é dividida pelo total de diárias necessárias nas atividades. Considerou-se que a maioria dos serviços humanos é executada por membros de sua família, presumindo-se a capacitação dos mesmos (RÊGO, 2014). Foram adotados os valores de custo de oportunidade de R \$30,00 para a safra 2013/2014 e $\mathrm{R} \$ 40,00$ para a safra posterior

\subsection{5 - Receita líquida}

Renda líquida é definida como a diferença entre a receita bruta e o custo total (SANTOS et al., 2002), é o valor excedente apropriado pela unidade de produção familiar depois de repostos os valores dos meios de produção e serviços prestados à produção (CASTELO, 2000).

A RL foi estimada de acordo com Santos et al., (2002):

$$
R . L=\Sigma R_{j}-\Sigma C_{j}
$$

Onde:

$\mathrm{R}_{j}=$ Receita total da safra, $\mathrm{R} \$ . \mathrm{safra}^{-1}$;

$\mathrm{C}_{j}=$ Custo total do período, $\mathrm{R} \$ . \mathrm{safra}^{-1}$; 
A receita líquida representa uma fração da renda Bruta que fica disponível depois que o produtor pagar todos os custos e ter distribuído as remunerações julgadas normais (custo de oportunidades) aos fatores utilizados (mas não pagos), ou seja, seu próprio trabalho (executivo e gerencial), o trabalho familiar, os seus próprios capitais (CASTELO, 2000).

\section{4 - RESULTADOS E DISCUSSÃO}

\section{1 - PERFIL DOS AGROEXTRATIVISTAS}

Ao estudar a produção de baru, foi observado que as castanhas são produzidas unicamente pela atividade extrativa. Foram identificadas cinco (5) regiões produtivas (tabela 01), são localidades com alta densidade de baruzeiros onde ocorre o processo do extrativismo do baru. Do total de observações $73,33 \%$ são agricultores familiares e desse total 43,33\% são assentados de reforma agrária, informação coincidente com os estudos de Bispo e Diniz (2014).

Tabela. 2- Número de entrevistas e atividades com renda por regiões estudadas

\begin{tabular}{lccc}
\hline \multicolumn{1}{c}{ Região } & Número & $\begin{array}{c}\text { Número de } \\
\text { entrevistas }\end{array}$ & $\begin{array}{c}\text { Número de atividades } \\
\text { geradoras de renda }\end{array}$ \\
\hline Chico Mendes & I & 6 & $5-6$ \\
Rancharia & II & 8 & $5-6$ \\
Sagarana & III & 10 & $3-4$ \\
Igrejinha & IV & 3 & $5-6$ \\
Santiago & V & 3 & $4-5$ \\
TOTAL & 5 & 30 & 6 \\
\hline
\end{tabular}

Fonte: Pesquisa de Campo (2015).

A população de agroextrativistas foi estimada em 119 famílias que atuaram nas safras estudadas, esse valor representa $2,21 \%$ das famílias do município. O esforço amostral foi estimado em 27 entrevistas, no entanto, foram entrevistadas 30 famílias (tabela 1).

Do universo pesquisado, as famílias exercem de 3 a 6 atividades que geram renda (tabela 01), desenvolvendo atividades agropecuárias, domésticas e extrativistas concomitantemente, sendo denominado de agroextrativistas nesse estudo. 
Dentre as práticas produtivas e/ou benefícios sociais que mais contribuem na formação da renda das famílias agroextrativistas destacam-se a comercialização do baru, com 26,67\% das observações, enquanto que a pecuária leiteira foi citada por 23,33\%. Aposentadoria e trabalho assalariado foram citados por $13,33 \%$ dos entrevistados (figura 3 ).

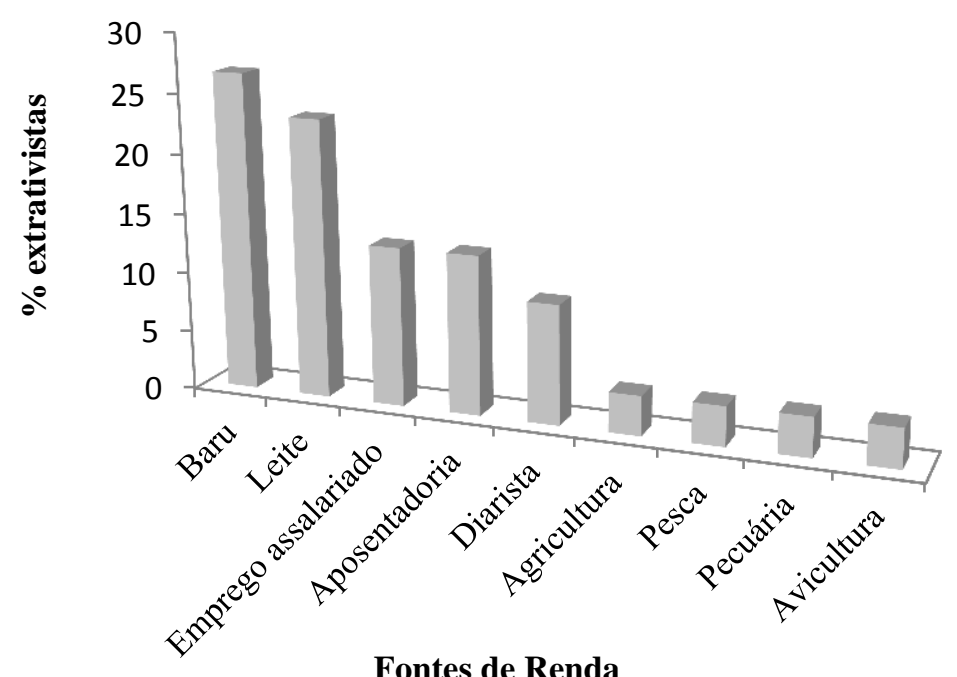

Figura 3- Renda principal declarada pelos entrevistados.

Quanto à participação em programas de transferência de renda, 63,33\% dos entrevistados são beneficiários do Programa Bolsa Família, encontrando-se em situação de vulnerabilidade social. Ao comparar a renda das famílias com o salário mínimo, os agroextrativistas obtiveram uma média de 1,91 salários mínimos em 2013 e 1,83 salários em 2014 (tabela 02).

Quanto à relevância da economia do baru na composição da renda, foi observado que, na safra de 2013/2014, o baru compôs em média 21,39\% da renda das famílias e na safra de 2014 foi de 14,63\% (tabela 02). Essa queda significativa é resultado da quebra de produção das safras em análise, ocasionada pela volatilidade da produção. Evidencia-se que as receitas proporcionadas pelo baru são complementares à renda familiar, sendo, no entanto executada no período de estiagem, quando normalmente as atividades agropecuárias não ocupam muita mão de obra.

Essa relação de complementariedade na renda coincide com os resultados encontrados por Carneiro (2014) e Pimentel et al. (2009), que ao estudar o extrativismo do baru em 
Pirenópolis/GO, constataram que a renda do baru compôs $12,34 \%$ da renda familiar na safra de 2005 e $8,44 \%$ na safra de 2007.

Tabela 3 - Renda anual e percentual da renda resultante do comércio do baru

\begin{tabular}{|c|c|c|c|c|c|c|}
\hline & \multicolumn{3}{|c|}{2013} & \multicolumn{3}{|c|}{2014} \\
\hline $\begin{array}{c}\mathrm{N}^{\mathbf{0}} \\
\text { famílias }\end{array}$ & $\begin{array}{c}\text { Renda } \\
\text { anual (R\$) }\end{array}$ & $\begin{array}{c}\text { Baru na } \\
\text { renda }(\%)\end{array}$ & $\begin{array}{l}\text { Proporçã } \\
\text { o salário }\end{array}$ & $\begin{array}{c}\text { Renda anual } \\
(\mathrm{R} \$)\end{array}$ & $\begin{array}{l}\text { Baru na } \\
\text { renda }(\%)\end{array}$ & $\begin{array}{l}\text { Proporçã } \\
\text { o salário }\end{array}$ \\
\hline 1 & $18.503,65$ & 13,51 & 2,27 & $16.403,65$ & 5,49 & 1,89 \\
\hline 2 & $23.939,40$ & 3,57 & 2,94 & $23.964,40$ & 2,67 & 2,76 \\
\hline 3 & $4.990,00$ & 32,06 & 0,61 & $4.540,00$ & 24,23 & 0,52 \\
\hline 4 & $9.024,00$ & 44,33 & 1,11 & $7.024,00$ & 28,7 & 0,81 \\
\hline 5 & $8.450,00$ & 8,88 & 1,04 & $7.790,00$ & 1,16 & 0,90 \\
\hline 6 & $7.584,00$ & 19,78 & 0,93 & $8.034,00$ & 12,45 & 0,92 \\
\hline 7 & $9.793,50$ & 5,31 & 1,20 & $10.929,67$ & 7,32 & 1,26 \\
\hline 8 & $4.760,00$ & 54,62 & 0,59 & $4.000,00$ & 20,00 & 0,46 \\
\hline 9 & $23.342,00$ & 33,42 & 2,87 & $19.218,00$ & 14,5 & 2,21 \\
\hline 10 & $11.814,00$ & 16,51 & 1,45 & $13.274,00$ & 16,95 & 1,53 \\
\hline 11 & $12.444,00$ & 52,23 & 1,53 & $8.494,00$ & 5,30 & 0,98 \\
\hline 12 & $18.052,80$ & 28,80 & 2,22 & $13.036,80$ & 0,00 & 1,50 \\
\hline 13 & $22.556,00$ & 6,92 & 2,77 & $24.260,00$ & 8,90 & 2,79 \\
\hline 14 & $10.844,00$ & 1,84 & 1,33 & $11.816,00$ & 2,20 & 1,36 \\
\hline 15 & $7.746,67$ & 10,07 & 0,95 & $8.966,67$ & 10,04 & 1,03 \\
\hline 16 & $37.244,00$ & 8,59 & 4,58 & $38.536,00$ & 6,49 & 4,44 \\
\hline 17 & $37.600,00$ & 4,26 & 4,62 & $38.760,00$ & 7,12 & 4,46 \\
\hline 18 & $12.786,00$ & 15,25 & 1,57 & $14.588,00$ & 21,94 & 1,68 \\
\hline 19 & $8.600,00$ & 30,23 & 1,06 & $11.400,00$ & 47,37 & 1,31 \\
\hline 20 & $13.380,00$ & 98,65 & 1,64 & $23.868,00$ & 62,5 & 2,75 \\
\hline 21 & $16.212,00$ & 37,01 & 1,99 & $20.764,00$ & 48,6 & 2,39 \\
\hline 22 & $8.820,00$ & 7,76 & 1,08 & $9.938,00$ & 12,58 & 1,14 \\
\hline 23 & $13.146,00$ & 17,12 & 1,62 & $13.848,00$ & 17,33 & 1,59 \\
\hline 24 & $9.748,00$ & 21,34 & 1,20 & $10.644,00$ & 25,37 & 1,23 \\
\hline 25 & $31.410,00$ & 2,39 & 3,86 & $31.660,00$ & 3,16 & 3,64 \\
\hline 26 & $17.468,00$ & 14,88 & 2,15 & $16.446,00$ & 4,56 & 1,89 \\
\hline 27 & $18.976,00$ & 4,80 & 2,33 & $18.624,00$ & 1,64 & 2,14 \\
\hline 28 & $31.358,50$ & 4,78 & 3,85 & $30.950,50$ & 1,74 & 3,56 \\
\hline 29 & $6.350,00$ & 30,71 & 0,78 & $6.290,00$ & 18,60 & 0,72 \\
\hline 30 & $8.093,00$ & 12,05 & 0,99 & $8.762,00$ & 0,91 & 1,01 \\
\hline Média & $15.501,18$ & 21,39 & 1,91 & $15.894,32$ & 14,63 & 1,83 \\
\hline
\end{tabular}

Fonte: Pesquisa de Campo (2015).

Geralmente as famílias agroextrativistas que possuem uma proporção expressiva da renda do baru, compram parte de sua produção de frutos de outros coletores. A coleta dos frutos é considerada por $66,67 \%$ dos entrevistados como a pior atividade do comércio do baru, no 
entanto somente dois entrevistados consideram o beneficiamento. Quando os frutos são coletados pelos próprios agroextrativistas, $86,67 \%$ preferem vender a castanha, ao invés do fruto in- natura.

Mesmo com as dificuldades apresentadas, 76,66\% dos agroextrativistas estariam dispostos a investir recursos próprios na produção das castanhas de baru, buscando melhorias no processo produtivo. Em relação à preservação do baru, 100\% afirmam que diminuíram os cortes das árvores de baru, após o início do processo de comercialização das castanhas.

\section{2 - PROCESSO PRODUTIVO E COMÉRCIO DO BARU}

A atividade do extrativismo do fruto do baru ocorre principalmente em áreas de pastagens, onde $73,33 \%$ dos entrevistados praticam a coleta, que ocorre geralmente em terras de terceiros, em 83,33\% dos casos. Geralmente a coleta é realizada com consentimento do proprietário, que em 90\% dos casos, permite o livre acesso aos baruzeiros.

Foi observado que $10 \%$ dos agroextrativistas coletam frutos na condição de repassar parte da produção ao proprietário, esse acordo vem ocorrendo na região de Sagarana. A proporção dos frutos que ficam com os proprietários variam, podendo ser dez por cento, um terço ou a metade dos frutos coletados.

A coleta normalmente ocorre entre os meses de agosto e novembro, geralmente cessando com a chegada do período chuvoso. Os frutos são acondicionados em sacos de ração animal, sendo depositados provisoriamente debaixo das árvores de baru até seguirem para o local de depósito.

O tempo médio de dedicação na atividade da coleta é de 3,12 meses, período em que coletam em média 6,4 sacos por dia de trabalho, percorrem 6,3 quilômetros em média, possuindo em média 3,48 rotas de coletas, em que visitam 13 árvores por rota.

Ao término da coleta é realizado o transporte interno da produção, que consiste no transporte da área de coleta até o local de armazenamento. Os principais meios de transporte da produção é a carroça (figura 04) e o carro, com 56,67\% e $40 \%$ 
respectivamente, que permitem transportar aproximadamente 5,5 sacos de 60 quilos por viagem.

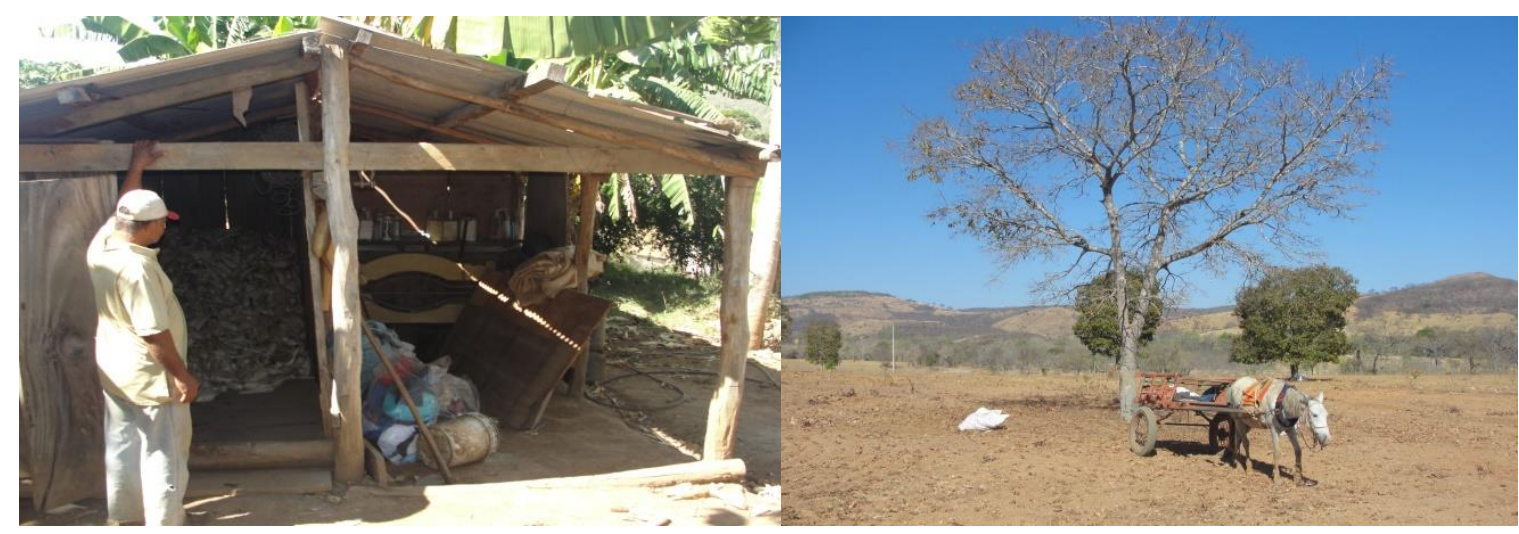

Figura 4 - Local de armazenamento e veículo mais utilizado no transporte.

Os agroextrativistas associam diversos tipos de transporte, raramente contratam-se tratores e caminhões para transporte de volumes maiores, sendo que somente 33,33\% utilizam transportes contratados. Para os agricultores que possuem áreas de coletas mais próximas de suas residências, utiliza-se o carrinho de mão, enquanto os menos capitalizados, que não possuem carroça ou carro, utilizam-se da bicicleta (figura 05).

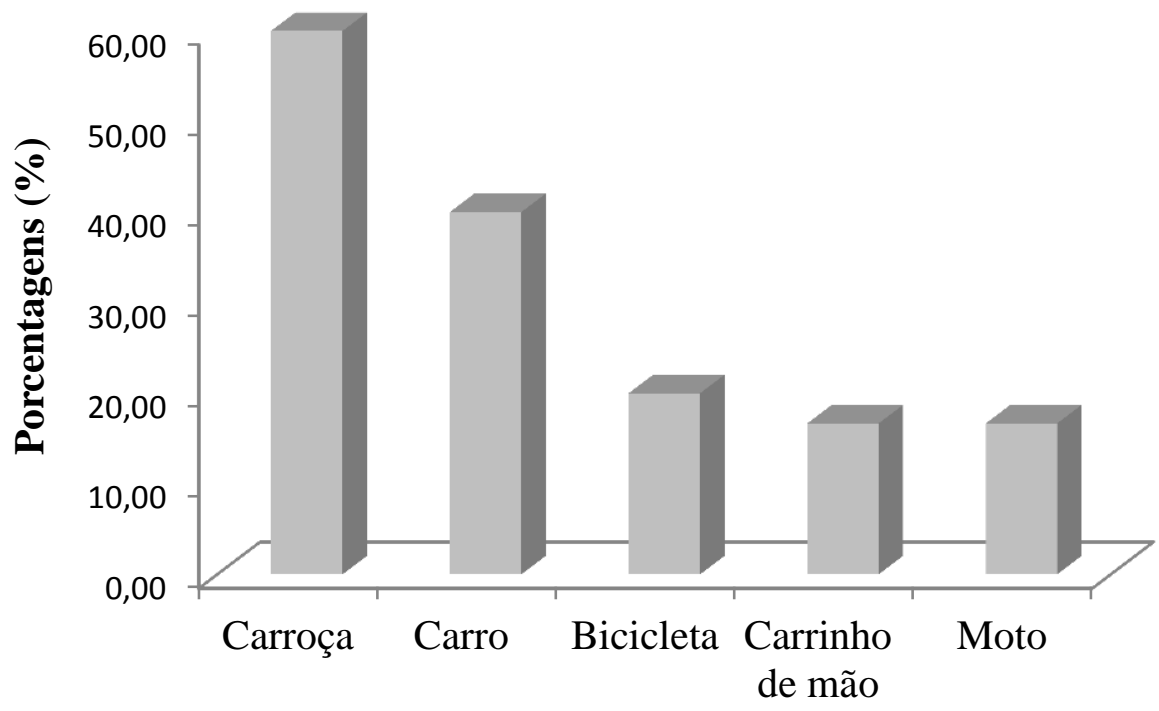

Figura 5 - Tipos de veículos utilizados no transporte do baru

O armazenamento da produção ocorre como uma etapa preparatória para o beneficiamento e comercialização rápida da produção. Os agricultores não possuem estratégias de venda, que aproveitem a sazonalidade da produção, possibilitando a venda da produção com 
preços mais elevados na entressafra. Os frutos ficam em média 3,68 meses armazenados, durante esse tempo, os agricultores vão beneficiando conforme a demanda de compra das sementes.

Esse armazenamento ocorre em cômodos de suas próprias residências, $40 \%$ dos entrevistados, podendo ser na varanda, ou algum cômodo interno desocupado. Outros locais utilizados para o armazenamento foram em galpões e paiois (figura 06), com $26,67 \%$ e $20 \%$ respectivamente.

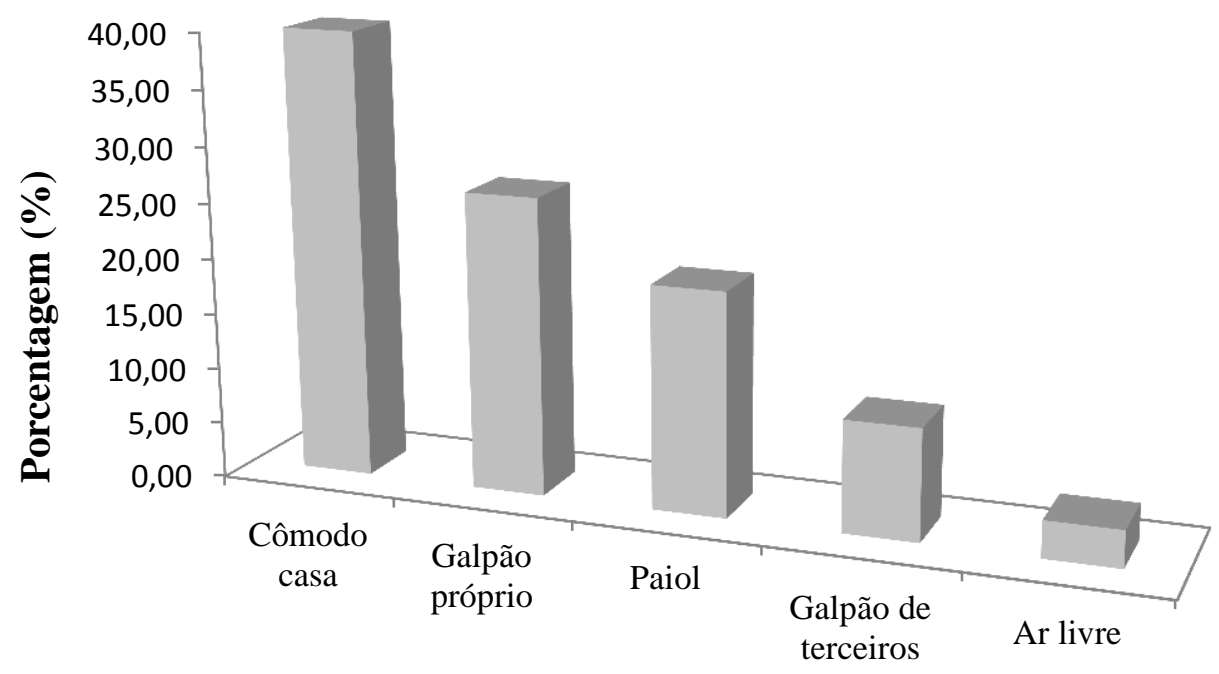

Figura 6 - Locais de armazenamento dos frutos coletados.

Considerado por $23,33 \%$ como a pior atividade da cadeia produtiva do baru, o beneficiamento do fruto é determinante nos custos de produção da castanha, pois compõe metade dos custos totais de produção. A ferramenta utilizada para o pré-beneficiamento do fruto, pode ser um machado, facão ou foice, adaptados sob uma base de madeira (figura 07), com o qual se quebra o endocarpo lenhoso e extrai-se a semente. Esse equipamento é utilizado por $63,33 \%$ dos agroextrativistas entrevistados. Outro equipamento muito utilizado é uma adaptação da foice de ferro convencional, fixada a uma base do mesmo material, método utilizado por $56,66 \%$ dos entrevistados. Nessa análise deve-se considerar que $20 \%$ possuem os dois equipamentos. 


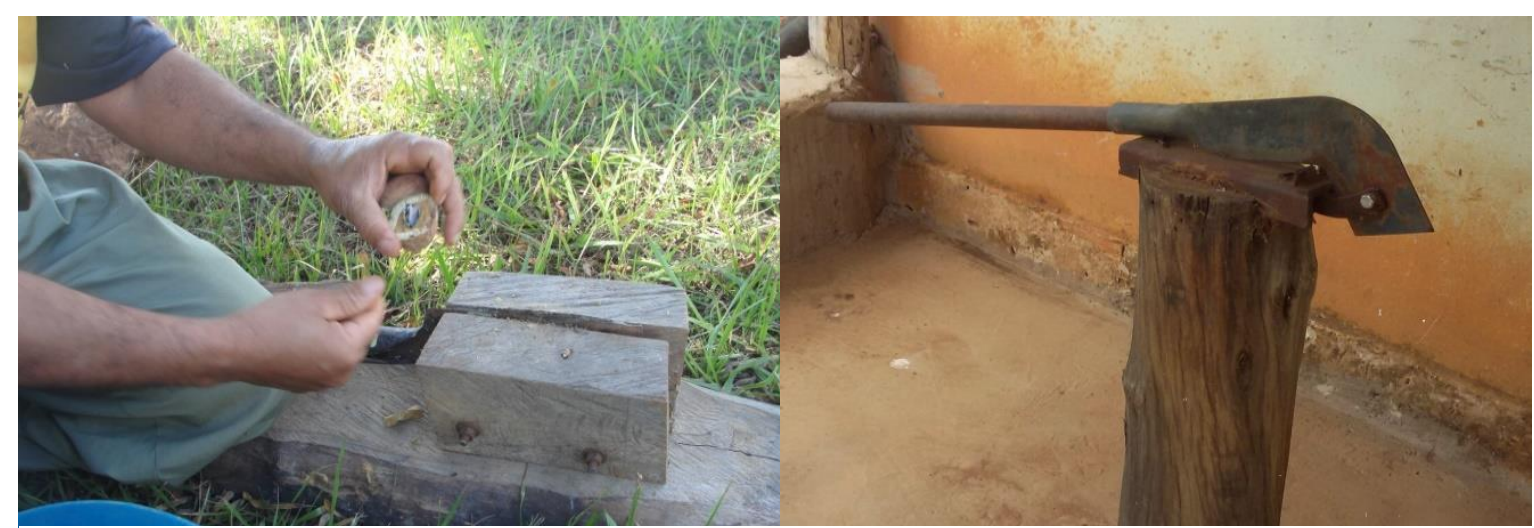

Figura 7 - Equipamentos mais utilizados para a quebra dos frutos.

Ao estudar o processo produtivo dos PFNMs do baru, Pimentel et al. (2009) avaliaram os rendimentos operacionais da etapa de beneficiamento, estimando um rendimento de $0,04066 \mathrm{~kg}$ de castanha de baru por quilo de fruto quebrado, que equivale a 4,2\% do fruto do baru. Foi definido também que um trabalhador, em seis horas de trabalho, consegue beneficiar 56,25 $\mathrm{kg}$ de frutos, que rendem 2,36 quilos de sementes selecionadas por dia (PIMENTEL, 2009).

Ao comparar três técnicas diferentes para o beneficiamento do baru, Botezelli et al. (2000), utilizaram prensa hidráulica, morsa e martelo com suporte em ferro. Dentro das técnicas empregadas, o martelo foi descartado da análise pelos danos causados à semente. Os autores consideraram o rendimento da extração da castanha lento, produzindo $1,13 \mathrm{~kg}$ por 6 horas de trabalho, utilizando a morsa e $0,89 \mathrm{~kg}$ com a prensa hidráulica. Em técnicas de entrevistas realizadas por Sano et al. (2004), apurou um rendimento de $2 \mathrm{~kg}$ de castanha/homem/dia.

Nesse estudo os agroextrativistas produzem em média 4,46 kg de baru, por dia de trabalho, diferindo, portanto dos estudos apresentados. Essa diferença pode ter ocorrido pela maior experiência e habilidade dos extrativistas entrevistados, e/ou pela maior eficiência da técnica utilizada ou tempo de dedicação superior a 6 horas diárias. As sementes são selecionadas concomitantemente com a etapa de quebra dos frutos, durante esse processo algumas sementes são quebradas ou estão podres, a perda estimada foi de $7,78 \%$ do total produzido. 
Após essa etapa ocorre o acondicionamento das castanhas cruas devidamente selecionadas e prontas para a comercialização, os agroextrativistas acondicionam as sementes em garrafas de refrigerante reaproveitadas de Polietileno Tereftalato (garrafas PET). Esta forma de armazenamento foi observada em aproximadamente metade dos entrevistados (Figura 8). Uma pequena parte dos entrevistados reutilizam sacos plásticos resistentes disponibilizados pelo comércio, enquanto outros utilizam vasilhames domésticos.

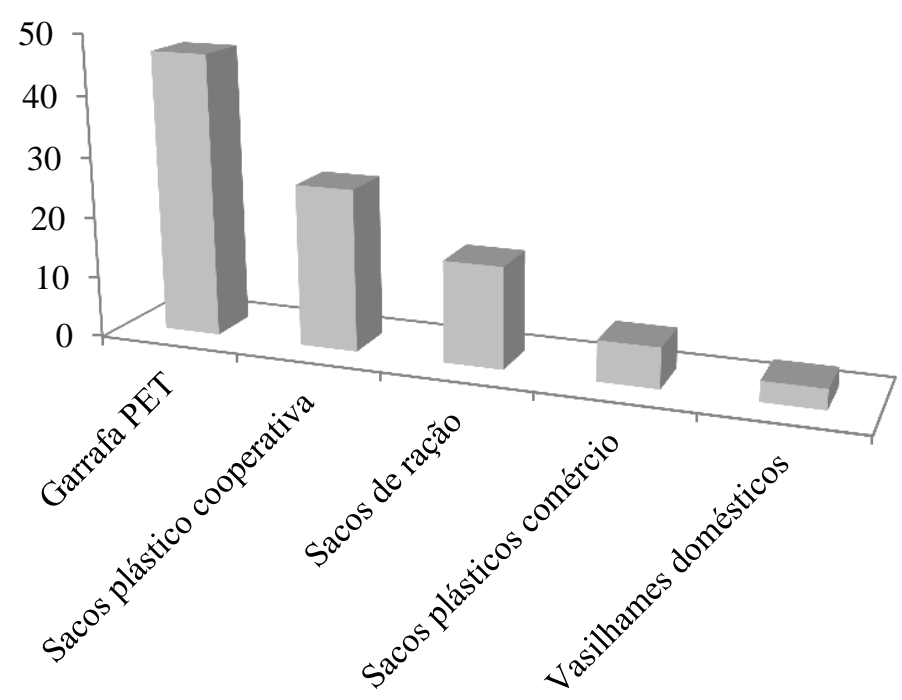

Figura 8 - Recipientes para comercialização da castanha.

Aproximadamente 26,67\% dos agroextrativistas utilizam sacos plásticos transparentes que são doados aos cooperados da Cooperativa da Agricultura Familiar Sustentável com Base na Economia Solidaria (COPABASE). Esses sacos são próprios para comercialização de castanhas, proporcionando melhorias nos aspectos fitossanitários no acondicionamento do baru.

A COPABASE é uma cooperativa com base da agricultura familiar, suas ações são voltadas para a sustentabilidade e os princípios da economia solidária. Seu regime jurídico é de sociedade civil e comercial, sem fins lucrativos. A COPABASE foi criada com o intuito de gerar renda para as famílias da região do Vale do Rio Urucuia por meio da comercialização dos produtos da agricultura familiar, que precisavam se organizar economicamente (COPABASE, 2013). Do total de entrevistados, 36,67\% pertencem à COPABASE. 
Ao analisar o acesso dos agroextrativistas à assistência técnica, social e ambiental (ATES), foi observado que praticamente metade não recebe nenhuma assistência (figura 09). Recentemente o Instituto Nacional de Colonização e Reforma Agrária/INCRA contratou equipe técnica para atendimento da ATES, em somente 10\% dos casos. Aproximadamente $27 \%$ dos entrevistados recebem assistência da COPABASE e 10\% recebem assistência do INCRA e da COPABASE concomitante.

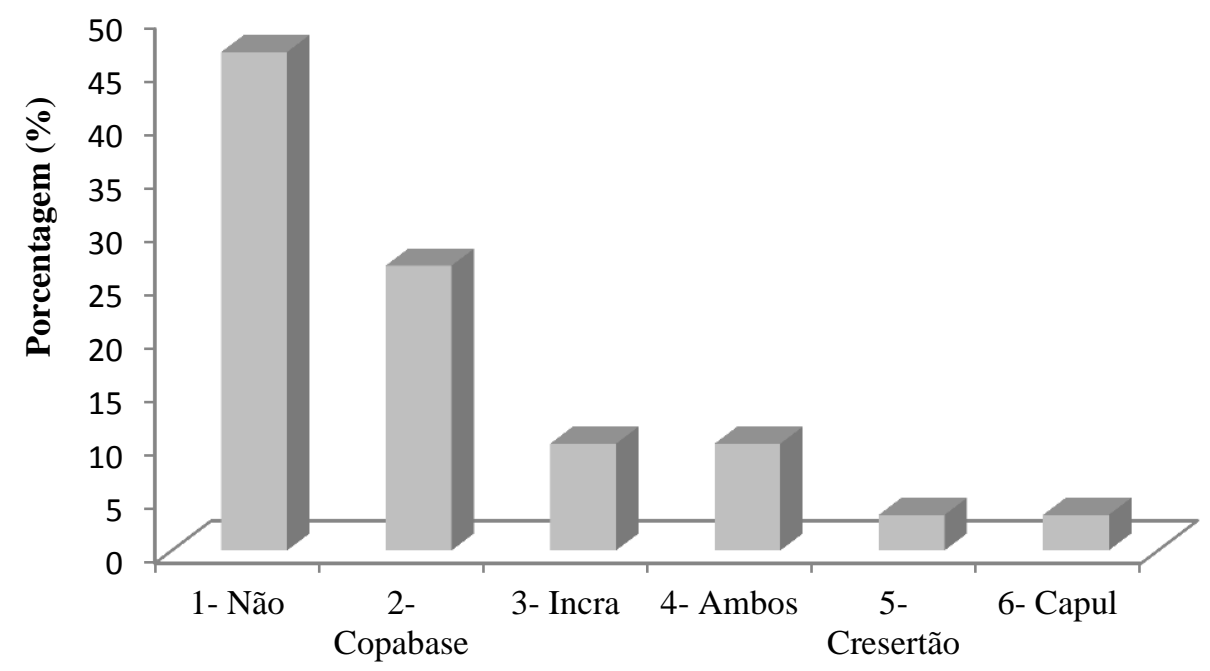

Figura 9 - Porcentagens de agroextrativistas atendidos e não atendidos pela ATES.

Fonte: Dados de campo

No entanto, $86,67 \%$ dos entrevistados afirmaram que não receberam orientações sobre práticas de extrativismo sustentável, refletindo na baixa porcentagem de frutos deixados no campo para alimentação da fauna e para dispersão da espécie, somente $15,66 \%$ dos entrevistados usam essa prática. No estudo de Pimentel et al. (2009) 25\% dos entrevistados deixam frutos no campo, enquanto 50\% deixaram frutos no estudo de Bassini (2008).

Esse resultado indica que iniciativas de plantio racional devem ser adotadas, podendo utilizar técnicas silviculturais distintas, como enriquecimento florestal de áreas de cerrado degradado, sistemas agroflorestais, quintais domésticos, plantios puros, etc. Esses plantios podem criar novas áreas de produção, ampliando a oferta de frutos, diminuindo custos e contribuindo com a preservação da espécie. 
Orientações no sentido de mitigar o impacto da coleta dos frutos devem ser adotadas, procurando deixar um terço dos frutos no campo, conforme recomendado por Carraza e Ávila (2010).

Resumidamente o agroextrativista médio do Vale do Urucuia caracteriza-se por ser pluriativo, coletando os frutos entre os meses de julho e outubro, geralmente nas pastagens de propriedades de terceiros. Os frutos são coletados em baldes reutilizados, e posteriormente são acondicionados em sacos de ração animal, que são doados por fazendeiros da região. O transporte é realizado por carros e/ou carroças e posteriormente armazenados em paióis e/ou cômodas de suas residências.

O beneficiamento dos frutos é executado pelos agroextrativistas utilizando uma foice adaptada e/ou um toco com lâmina. A comercialização ocorre concomitantemente com o beneficiamento, e geralmente em janeiro e/ou fevereiro do ano subsequente todas as castanhas foram comercializadas.

Os agroextrativistas mais produtivos costumam adquirir frutos de coletores. Outra diferença em relação aos agroextrativistas médios é referente aos materiais da coleta, onde esse grupo compra parte dos sacos de ração utilizados.

O coletivo de agroextrativistas de Sagarana é a reunião dos mais produtivos dessa região. Todas as variáveis técnicas individuais do coletivo são iguais aos agroextrativistas mais produtivos.

\section{3 - PRODUÇÃO E COMERCIALIZAÇÃO}

O processamento integral do baru permite comercializar diversos produtos e subprodutos como, farinha do fruto, castanha torrada, manteiga, óleo refinado, farelo da semente, artesanato, ácido pirolenhoso e carvão (CARRAZA e ÁVILA, 2010).

Os agroextrativistas produzem e comercializam basicamente castanhas cruas, não aproveitando outros produtos e subprodutos e não agregam valor à produção. A etapa de torrefação das castanhas é realizada pela cooperativa e pelos intermediários, sendo que apenas $10 \%$ dos entrevistados praticam a torrefação do baru para a venda. 
O presente estudo analisou a comercialização do baru no município de Arinos, em duas safras distintas. Ao avaliar a produção de um produto nativo e extrativista, deve-se considerar a sua sazonalidade, onde a variação brusca na produção de frutos é frequente e afeta o planejamento do agroextrativista e fragmenta as relações comerciais (MAGALHÃES, 2014).

Com a sazonalidade da produção, a oferta e a demanda de castanhas são afetadas, assim como o preço pago ao agroextrativista, o ingresso de novas famílias no mercado, a atuação dos intermediários, entre outros. Analisar economicamente diferentes safras permite estudar o impacto da oscilação da produção na renda das famílias.

Foram analisadas as diferenças na produção e nos preços praticados na região Chico Mendes, Rancharia, Sagarana e Igrejinha, para tanto, foi realizada uma análise de variância (ANOVA) para auxílio na análise estatística e posteriormente as média foram comparadas pelo teste de Tukey a 5\% de probabilidade de erro.

O ano de 2013 foi considerado pelos entrevistados um ano de alta produção de frutos, e não houve diferenças significativas entre as regiões estudadas, dentro dos critérios selecionados (tabela 3).

Tabela 4 - Produção e preços praticados na safra e entressafra 2013/2014.

\begin{tabular}{lccc}
\hline Regiões & Preço safra (R\$) & Preço entressafra (R\$) & Produção (kg/castanha) \\
\hline I & $14,20 \mathrm{~b}$ & $19,80 \mathrm{~b}$ & $121,40 \mathrm{a}$ \\
II & $13,00 \mathrm{ab}$ & $13,66 \mathrm{a}$ & $230,00 \mathrm{a}$ \\
III & $13,12 \mathrm{ab}$ & $16,50 \mathrm{ab}$ & $185,00 \mathrm{a}$ \\
IV & $12,00 \mathrm{a}$ & $14,33 \mathrm{a}$ & $123,33 \mathrm{a}$ \\
\hline CV\% & 6,61 & 11,36 & 13,85 \\
\hline
\end{tabular}

Fonte: Pesquisa de Campo (2015).

Entretanto, ao se analisar a produção de baru na safra de 2014, as diferenças entre as regiões foram evidentes (tabela 4), destacando-se a região de Sagarana (Região III), distrito do município de Arinos, conhecido pelas citações no livro Grande Sertão Veredas do autor João Guimarães Rosa, onde parte da história se desenrola nas mediações desse distrito. No distrito de Sagarana ocorre a maior população de baruzeiros do município, proporcionando uma produção significativa, mesmo em épocas pouco produtiva. 
Tabela 5 - Produção e preços praticados na safra e entressafra 2014/2015.

\begin{tabular}{cccc}
\hline Regiões & Preço safra $(\mathbf{R} \$)$ & Preço entressafra (R\$) & Produção (kg/castanha) \\
\hline I & $20,60 \mathrm{~b}$ & $25,60 \mathrm{a}$ & $50,40 \mathrm{ab}$ \\
II & $17,33 \mathrm{a}$ & $22,66 \mathrm{a}$ & $78,33 \mathrm{ab}$ \\
III & $18,87 \mathrm{ab}$ & $23,50 \mathrm{a}$ & $183,75 \mathrm{~b}$ \\
IV & $18,00 \mathrm{ab}$ & $20,00 \mathrm{a}$ & $32,33 \mathrm{a}$ \\
\hline CV\% & 9,20 & 13,38 & 15,05 \\
\hline
\end{tabular}

Fonte: Pesquisa de Campo (2015).

Foi relatado por diversos entrevistados da Região III que, mesmo em anos de baixa produção, algumas árvores de baru produzem uma grande quantidade de frutos. Nesse caso, aumentando seu esforço de coleta, é possível manter uma boa produção, amenizando o impacto da volatilidade da produção na renda das famílias.

Outras variáveis que apresentaram diferenças significativas foram: o preço da safra e da entressafra do ano de 2013 e o preço da safra do ano de 2014. Os maiores preços foram praticados na região do Chico Mendes (I). Essa região possui fácil acesso a rodovias pavimentadas, facilitando o trânsito de intermediários, que geralmente remuneram melhor que a cooperativa, outro fator determinante nos maiores preços é a estratégia de armazenar os frutos e comercializar somente na entressafra, somente nessa região foi observada essa prática.

Em todas as outras regiões analisadas ocorreram grandes reduções na produção (tabela 5), acarretando perdas significativas na renda das famílias, conforme Tabela 5. Destacam-se as regiões I, II e IV, com uma redução na produção de 58,48\%, 65,94\% e 73,78\% respectivamente.

Tabela 6 - Diferença na produção nas diferentes safras analisadas

\begin{tabular}{ccccc}
\hline Regiões & $\begin{array}{c}\text { Produção 2013 } \\
\text { (kg/castanha) }\end{array}$ & $\begin{array}{c}\text { Produção 2014 } \\
\text { (kg/castanha) }\end{array}$ & $\begin{array}{c}\text { Diferença } \\
(\mathbf{K g})\end{array}$ & $\begin{array}{c}\text { Variação } \\
(\%)\end{array}$ \\
\hline I & 121,4 & 50,4 & 71 & $-58,484349$ \\
II & 230 & 78,33 & 151,67 & $-65,943478$ \\
III & 185 & 183,75 & 1,25 & $-0,6756757$ \\
IV & 123,33 & 32,33 & 91 & $-73,785778$ \\
\hline
\end{tabular}

Fonte: Pesquisa de Campo (2015). 
A atuação dos intermediários, que possuem baixos custos operacionais e maior capital de giro, proporcionou um canal de comercialização mais eficiente para escoar a produção. Por isso $40 \%$ dos agroextrativistas comercializam exclusivamente com intermediários, contra $23,38 \%$ de comercialização exclusiva com a cooperativa e $16,67 \%$ dos entrevistados comercializam com ambos (figura 10).

Foram produzidos em média 196,16 quilos e 112,38 quilos nas safras 2013/2014 e 2014/2015 respectivamente, considerando a taxa de perda apurada, resultam na produção de 182 quilos e 104, 27 quilos nas safras analisadas, uma redução de 42,71\% na produção.

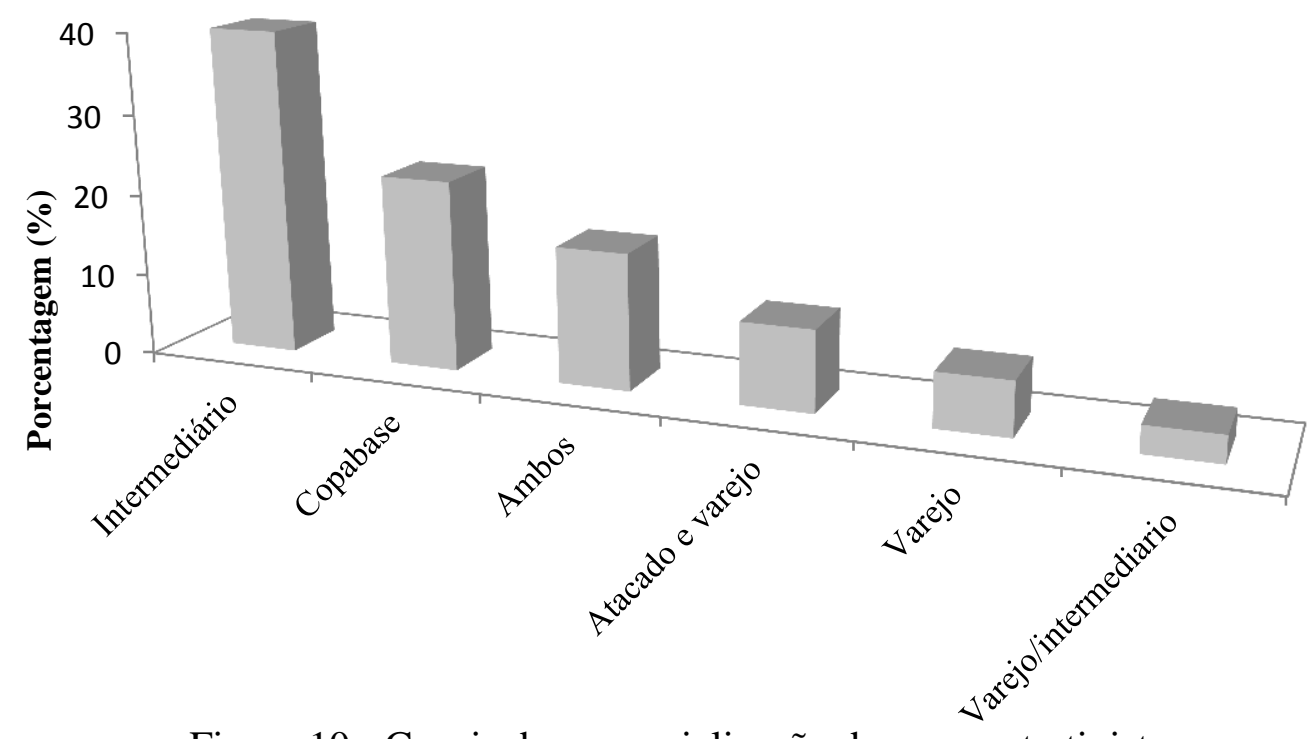

Figura 10 - Canais de comercialização dos agroextrativistas.

Considerando a população extrativista estimada em 119 famílias, a produção total foi de $21.658 \mathrm{~kg}$ e $12.408,13 \mathrm{Kg}$, proporcionando uma circulação de $\mathrm{R} \$ 314.257,58$ e $\mathrm{R} \$$ 259.826,24 na economia regional.

A produção da COPABASE na safra 2013/2014 foi de 5.224,24 quilos de castanha (tabela 6), que corresponde a 24,12\% da produção estimada do município de Arinos, ou seja, aproximadamente $75,88 \%$ da produção são comercializados informalmente.

A venda informal via intermediários ocorre sem notas ficais, sem tributos recolhidos, sem controle dos aspectos fitossanitários, ou seja, é uma produção invisível, não contabilizada pelos órgãos responsáveis. 
Tabela 7 - Quantidades produzidas e número de agroextrativistas cooperados.

\begin{tabular}{cccc}
\hline Ano & $\begin{array}{c}\text { Produção } \\
\text { (Kg/castanha) }\end{array}$ & $\begin{array}{c}\text { Número de famílias } \\
\text { agroextrativista }\end{array}$ & $\begin{array}{c}\text { Preço de venda à } \\
\text { COPABASE }\end{array}$ \\
\hline 2009 & 25,36 & 4 & 13 \\
2010 & 1040,31 & 25 & 13 \\
2011 & 981,72 & 36 & 13 \\
2012 & 1381,5 & 13 & 13 \\
2013 & 5224,24 & 35 & 13 \\
\hline
\end{tabular}

Fonte: COPABASE (2015).

A produção do extrativismo vegetal não madeireiro, em sua maioria, se concentra na Região Norte, com destaque para o açaí (Euterpe oleracea) $(93,0 \%)$ e a castanha-do-Brasil (Bertholletia excelsa) (95,9\%). Na Região Nordeste, se destacam as produções de amêndoas de babaçu (Orbignya phalerata Mart.) (99,7\%), fibras de piaçava (Attalea funifera Mart) (95,3\%) e pó de carnaúba (Copernicia prunifera Miller) (100,0\%). Na Região Sul sobressai apenas dois produtos: erva-mate (llex paraguariensis St. Hil.) $(99,9 \%)$ e pinhão (Araucaria angustifólia Bert.) (86,7\%) (IBGE, 2014).

O volume comercializado de baru (Dipteryx alata vog.) e demais frutos do cerrado, não consta nas edições do relatório da Produção Extração Vegetal e da Silvicultura (IBGE, 2014). A produção mais significativa desse importante produto florestal não madeireiro é recente, e por sua importância regional é importante a inclusão de sua produção anual nos dados do PEVS/IBGE, para acompanhamento da produção e analisar a importância econômica da espécie nas diversas regiões de ocorrência.

\section{4 - COEFICIENTES TÉCNICOS DO SISTEMA PRODUTIVO}

Para avaliar a viabilidade da atividade extrativa, é necessário quantificar o custo de produção, estudando as despesas envolvidas na execução de serviços, uso de materiais, equipamentos e benfeitorias nas etapas produtivas da produção da castanha de baru. Foram definidos os coeficientes técnicos e o tempo de uso de cada etapa de produção do baru, as variáveis técnicas das etapas produtivas estão detalhadas abaixo.

Foram coletados $4.824,28$ e $2.763,80$ quilos de frutos, que corresponde a 80,4 e 46,06 sacos de 60 quilos de fruto. Dedica-se em média 3,12 meses para a coleta dos frutos, 
coletando 6,4 sacos por dia, totalizando 12,56 dias de trabalho para coletar a safra 2013. Nas safras com baixa produção, como em 2014, foi necessário aumentar o esforço de coleta, aumentando o número de árvores visitadas. Nesse estudo considerou um aumento de $30 \%$ de dedicação a atividade de coleta, totalizando uma dedicação de 9,36 dias para a safra de 2014 (tabela 7).

Tabela 8 - Variáveis técnicas da etapa coleta de frutos.

\begin{tabular}{ccc}
\hline Atividade & Valor & Unidade \\
\hline Dedicação à coleta & 3,12 & Meses \\
Número de rotas & 3,48 & Un. \\
Número de árvores visitadas & 13,14 & Un. \\
Número de sacos coletados & 6,4 & Un./60kg/dia \\
Dias de dedicação à atividade $(2013)$ & 12,56 & h.d/2013 \\
Dias de dedicação à atividade (2014) & 9,36 & h.d/2014 \\
\hline
\end{tabular}

Fonte: Dados de campo (2015).

$\mathrm{Na}$ etapa de transporte são carregados em média 5,5 sacos de $60 \mathrm{~kg}$ em charretes e/ou carros, que corresponde a 14,59 e 8,38 viagens para o transporte interno da produção nas safras em estudo. A atividade de transporte externo para a comercialização foi estimada em 3 vezes na safra 2013 e 2 vezes na safra 2014. Outras informações da etapa de transporte encontram-se na tabela 8 .

Tabela 9 - Variáveis técnicas da etapa transporte interno.

\begin{tabular}{ccc}
\hline Atividade & Valor & Unidade \\
\hline Número de sacos transportados & 5,5 & Sacos/60 kg/dia \\
Percurso até local de coleta & 6,3 & $\mathrm{Km} / \mathrm{dia}$ \\
Percurso interno na propriedade & 2 & $\mathrm{Km} / \mathrm{dia}$ \\
Percurso total diário & 16,69 & $\mathrm{Km} / \mathrm{dia}$ \\
Viagens transporte interno (2013) & 14,49 & $\mathrm{Un} . / \mathrm{safra}$ \\
Viagens transporte interno (2014) & 8,38 & $\mathrm{Un} . / \mathrm{safra}$ \\
Gastos com combustível & 35,35 & $\mathrm{Km} / \mathrm{litro}$ \\
Gasto mensal com ração para cavalo & 60,00 & $\mathrm{Sacos} / 50 \mathrm{~kg}$ \\
Gasto anual manutenção de carroça & 263,00 & $\mathrm{R} \$ / \mathrm{anual}$ \\
Gasto mensal com manutenção de carroça & 21,92 & $\mathrm{R} \$ / \mathrm{mês}$ \\
Gasto mensal com manutenção de carro & 40,00 & $\mathrm{R} \$ / \mathrm{mês}$ \\
\hline
\end{tabular}

Onde: Un= Unidade, Fonte: Dados de campo (2015).

Para estudar a etapa do transporte da produção, deve-se analisar separadamente o transporte interno do externo. A etapa interna corresponde ao transporte da coleta até local de armazenamento da produção, enquanto o transporte externo é a etapa final da 
comercialização. Nele as castanhas são levadas até o próximo elo da cadeia, geralmente intermediários, cooperativa e raramente ao consumidor final.

A produção é armazenada, geralmente em paiol, galpão ou cômodos da residência do agroextrativista. O beneficiamento do baru é moroso e pouco produtivo, correspondendo a 43,52 dias de dedicação na safra 2013 e 25,16 em 2014 (tabela 9).

Tabela 10 - Coeficientes técnicos da etapa beneficiamento dos frutos.

\begin{tabular}{ccc}
\hline Atividade & Valor & Unidade \\
\hline Rendimento da quebra do fruto & 4,47 & $\mathrm{Kg} / \mathrm{dia}$ \\
Perda (sementes podres e quebradas) & 7,78 & Porcentagem $(\%)$ \\
Dias de dedicação a atividade (2013) & 43,52 & $\mathrm{~h} / \mathrm{d}$ \\
Dias de dedicação a atividade(2014) & 25,16 & $\mathrm{~h} / \mathrm{d}$ \\
\hline
\end{tabular}

Onde: $\mathrm{h} / \mathrm{d}=$ homem dia. Fonte: Pesquisa de Campo (2015).

As famílias cooperadas precisam levar a produção de baru até a cooperativa, no entanto, os intermediários geralmente buscam a produção nas comunidades. As famílias realizam o transporte externo de diversas formas, pelo ônibus de transporte escolar, por conhecidos que eventualmente se deslocam até a cidade, etc.

Ao se comparar a quantidade de mão de obra necessária para a execução dos serviços, foi observada uma diferença significativa. No ano de 2013, safra classificada como produtiva, foram necessários 58,97 dias de dedicação à atividade (tabela 10), enquanto 36,52 dias de dedicação foi o suficiente para a safra subsequente. Essa diferença ocorre principalmente pela quantidade de mão de obra requerida na etapa de beneficiamento dos frutos, que cresce proporcionalmente à produção de frutos.

Tabela 11 - Quadro resumo das variáveis técnicas dos serviços executados.

\begin{tabular}{ccccc}
\hline Especificação & un. & h/d (2013) & h/d (2014) & Época de execução \\
\hline Coleta dos frutos & h/d & 12,45 & 9,36 & Agosto a novembro \\
Quebra dos frutos & h/d & 43,52 & 25,16 & Agosto a fevereiro \\
Transporte externo & un. & 3,00 & 2,00 & Setembro a fevereiro \\
Total & h/d & 58,97 & 36,52 & Setembro a fevereiro \\
\hline
\end{tabular}

Onde: $\mathrm{h} / \mathrm{d}=$ homem dia, un. $=$ unidade. 
Ao analisar os materiais utilizados para a coleta, foi observado que a maioria dos materiais são doados ou reaproveitados. Em relação à aquisição de sacos de ração para coleta e armazenamento, somente o agroextrativista médio não adquire, geralmente são doados por produtores rurais. Outros materiais lançados nos custos foram as vestimentas utilizadas na coleta dos frutos, como calça, calçados e camisetas. Todos esses valores foram estimados e lançados nos custos variáveis.

Os valores dos serviços executados foram definidos considerando que os agroextrativistas dediquem o dia de trabalho exclusivamente às atividades de coleta e/ou beneficiamento. $\mathrm{Na}$ prática essas etapas podem ocorrer em algumas horas por dia, como coletar os frutos somente pela manhã, ou beneficiar somente à noite.

\section{5 - CUSTOS DE PRODUÇÃO}

Foram estimados os custos de produção da castanha crua. A análise de diferentes safras permite comparar qual a influência da volatilidade da produção nos indicadores econômicos e financeiros selecionados.

Os custos variáveis corresponderam a 93,60\% dos custos totais, destacando a coleta e a quebra dos frutos, com 14,46\% e 50,56\% respectivamente. Para a safra subsequente esses valores corresponderam a 93,24\%, 17,16\% e 46,13\% (tabela 11). Observa-se que o beneficiamento do fruto é responsável pela metade dos custos totais, demonstrando que essa etapa é determinante na viabilidade e rentabilidade da comercialização do baru.

O conhecimento do processo produtivo de produção da castanha de baru é importante, pois permite analisar a viabilidade econômica e financeira da atividade extrativa do baru. Para tal é necessário estudar os coeficientes técnicos e os custos de produção.

Devido à falta de controle sistemático das despesas e receitas advindas da atividade, buscou-se incorporar todos os custos citados pelos agroextrativistas, mesmo que, na prática, não ocorresse o desembolso financeiro pela maioria dos entrevistados. 
Tabela 12 - Custos variáveis estimados da atividade extrativa

\begin{tabular}{ccccccc}
\hline Itens & $\begin{array}{c}\text { Quant } \\
\text { (h/d) }\end{array}$ & $\begin{array}{c}\mathbf{2 0 1 3} \\
\text { Valor/Uni } \\
\mathbf{d}(\mathbf{R} \mathbf{})\end{array}$ & $\begin{array}{c}\text { Percent } \\
(\mathbf{\%})\end{array}$ & $\begin{array}{c}\mathbf{2 0 1 4} \\
\text { Quant } \mathbf{d})\end{array}$ & $\begin{array}{c}\text { Valor/Un } \\
\text { id (R\$) }\end{array}$ & $\begin{array}{c}\text { Percent } \\
(\mathbf{\%})\end{array}$ \\
\hline Coleta & 12,45 & 30,00 & 14,46 & 9,36 & 40,00 & 17,87 \\
Alimentação animal & 3,12 & 60,00 & 7,25 & 3,12 & 60,00 & 8,94 \\
Manutenção/carroça & 3,12 & 21,92 & 2,65 & 3,12 & 21,92 & 3,26 \\
Manutenção/carro & 3,12 & 40,00 & 4,83 & 3,12 & 40,00 & 5,69 \\
Combustível & 5,79 & 4,36 & 0,98 & 3,35 & 10,38 & 1,69 \\
Transporte externo & 3,00 & 30,00 & 3,49 & 2,00 & 40,00 & 3,82 \\
Custo passagens & 3,00 & 30,00 & 3,49 & 2,00 & 30,00 & 2,86 \\
Beneficiamento & 43,52 & 30,00 & 50,56 & 25,6 & 40,00 & 48,04 \\
Materiais utilizados & 1,00 & 122,86 & 4,76 & 1,00 & 105,06 & 5,02 \\
Custos administrat & 3,12 & 9,30 & 1,12 & 3,12 & 9,30 & 1,39 \\
Total & & & $\mathbf{9 4 , 2 2}$ & & & $\mathbf{9 3 , 2 4}$ \\
\hline
\end{tabular}

Fonte: Dados de campo (2015).

Entre os principais custos fixos avaliados destacam-se a depreciação de benfeitorias e equipamentos. Foi calculada a depreciação do paiol e da carroça, pois são intensamente utilizados durante a safra. A remuneração do capital fixo foi calculada utilizando-se a recuperação do capital utilizado na construção do paiol para armazenamento.

O valor do bem novo da carroça foi orçado no comércio local, enquanto que o custo do paiol foi definido a partir do valor estabelecido por Leite et al. (2014). Para determinar a vida útil, a taxa anual de depreciação e o valor residual, foi utilizada a metodologia da Conab (2010), os valores estimados constam na tabela 12.

Tabela 13 - Custos fixos médios estimados da atividade extrativa.

\begin{tabular}{ccccc}
\hline & $\begin{array}{c}\mathbf{N}^{\mathbf{0}} \\
\text { Especificações }\end{array}$ & $\begin{array}{c}\text { Valor } \\
\text { Utilizaçocoses }\end{array}$ & $\begin{array}{c}\text { Participação } \\
\text { custos (\%) 2013 }\end{array}$ & $\begin{array}{c}\text { Participação } \\
\text { custos (\%) } \\
\mathbf{2 0 1 4}\end{array}$ \\
\hline Remuneração do capital fixo & - & 6,58 & 0,27 & 0,30 \\
Seguro capital fixo & - & 0,65 & 0,01 & 0,01 \\
Depreciação veículo & 35,09 & 69,77 & 2,82 & 3,20 \\
Depreciação da carroça & 52,63 & 11,91 & 0,48 & 0,55 \\
Depreciação residência & 755,91 & 53,36 & 2,16 & 2,45 \\
Depreciação do paiol & 755,91 & 5,88 & 0,24 & 0,27 \\
Depreciação foice adaptada & 188,98 & 2,28 & 0,09 & 0,09 \\
Total & & $\mathbf{1 4 9 , 7 9}$ & $\mathbf{6 , 0 6}$ & $\mathbf{6 , 8 7}$ \\
\hline
\end{tabular}

Fonte: Dados de campo (2015). 
Ao diminuir o volume de comercialização devido à volatilidade da produção, é necessário aumentar o esforço de coleta. Essa diferença foi observada nos custos da coleta nas diferentes safras, que anteriormente compunham $14,46 \%$ dos custos totais e passaram para 17,87\% para a safra subsequente (figura 11). Ao comparar as diferenças entre os custos de produção das duas safras, foi observado o aumento no valor unitário da mão de obra, que passou de $\mathrm{R} \$ 30,00$ para $\mathrm{R} \$ 40,00$, essa diferença, afetou diretamente a rentabilidade da atividade extrativista.

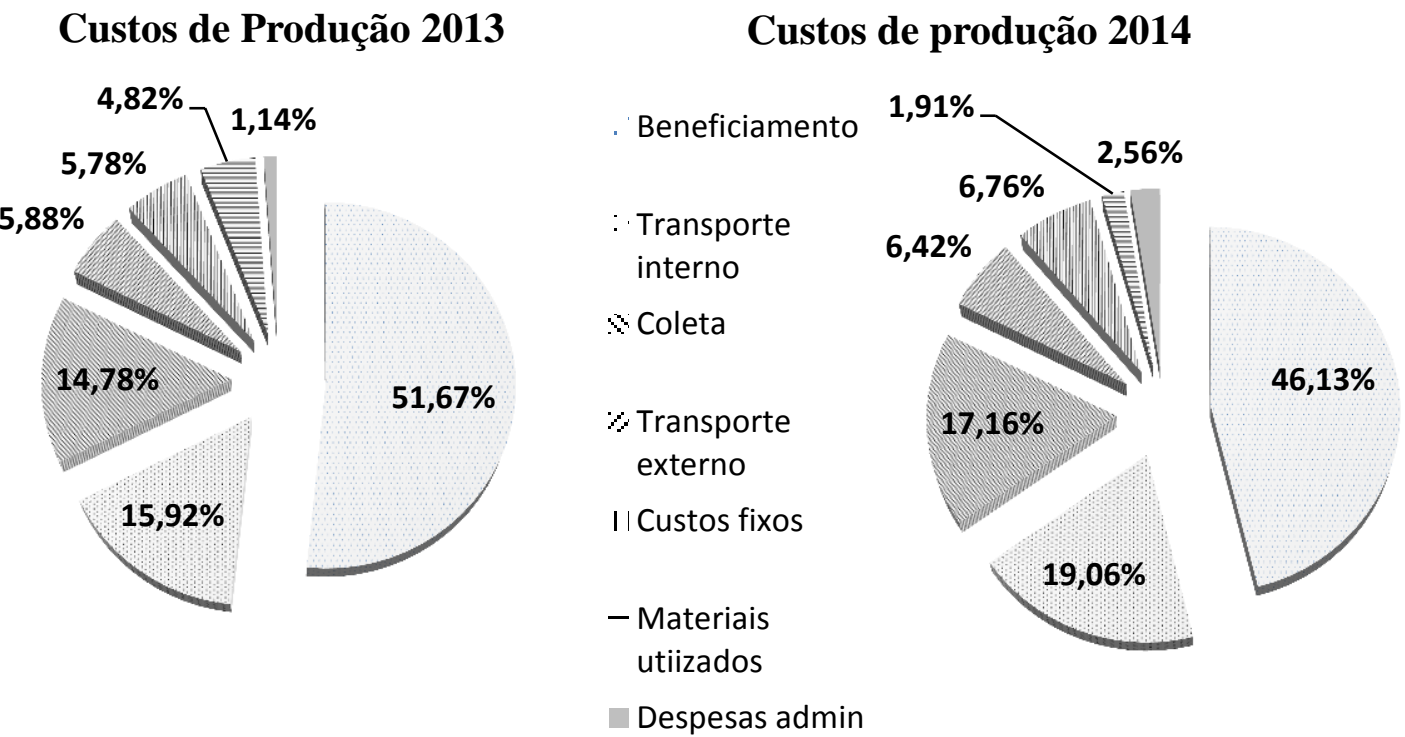

Figura 11 - Composição dos custos das safras analisadas.

Os custos estimados dos agroextrativistas coletivos foram definidos utilizando as variáveis técnicas dos agroextrativistas mais produtivos. Foram estimadas economias nos custos fixos e variáveis (tabela 13).

Tabela 14 - Custos variáveis estimados para o coletivo de agroextrativista

\begin{tabular}{ccc}
\hline Itens & Custos Variáveis totais (R\$) & Redução (\%) \\
\hline Combustível carro Produtivo & 177,66 & $14,28 \%$ \\
Combustível carro médio & 240,12 & $14,28 \%$ \\
Combustível carro baixa & 302,58 & $14,28 \%$ \\
Custos fixos & 748,9 & $28,57 \%$ \\
Manutenção carro & 756,9 & $14,28 \%$ \\
Manutenção carroça & 299,1 & $14,28 \%$ \\
Alimentação animal & $1.135,38$ & $14,28 \%$ \\
Transporte externo & 1.440 & $42,85 \%$ \\
\hline
\end{tabular}


Fonte: Dados de campo (2015).

$\mathrm{Na}$ ausência de estudos acadêmicos que quantifiquem o efeito da organização dos agricultores na redução dos custos de produção, foi necessário propor cenários de redução nas despesas.

Foi estabelecido uma economia de $14,28 \%$ nos custos do transporte interno, o planejamento coletivo das rotas de coletas, proporcionam uma melhora na alocação de recursos, proporcionando diminuição de custos. Essa organização permitiria uma redução em manutenções de carros e carroças.

Seriam utilizados cinco paióis para armazenamento, que somados a redução do uso de carros e carroças, diminuindo sua depreciação, permitiriam uma economia de 28,75\% nos custos fixos. Os paióis para armazenamento seriam escolhidos conforme a proximidade das áreas de coleta. Não foi previsto a compra de frutos e os valores da quantidade de mão de obra de coleta e beneficiamento manteve inalterada.

Foi proposta a necessidade de 32 viagens até o município de Arinos para comercializar a produção, que significa uma redução de 28,57\% na quantidade de transporte externo. Os materiais necessários para a safra e o número de paióis tiveram uma redução de 28,57\%.

O custo unitário de produção foi estimado em $\mathrm{R} \$ 13,26$ por quilo da castanha crua na safra de 2013/2014 e R \$ 19,41 na safra subsequente. O custo total foi de R \$2.601,08, referente a uma produção de $196,16 \mathrm{~kg}$ e $\mathrm{R} \$ 2.181,29$ para uma produção de $112,38 \mathrm{~kg}$ respectivamente.

A Conab estimou o custo de produção do extrativismo das castanhas de baru para a safra 2015/2016, ficando os custos variáveis responsáveis por $90,81 \%$ dos custos totais, somando as despesas com a mão de obra extrativista, que totalizaram 79,21\%, as despesas com embalagem e rótulos somaram 10,30\% aos custos. O transporte externo totalizou $8,11 \%$. As despesas administrativas e juros somaram $1,3 \%$ e $0,88 \%$ respectivamente. Os custos fixos somaram somente $0,2 \%$, destacando-se as depreciações, com $0,10 \%$, seguro capital fixo, com $0,01 \%$ e remuneração capital fixo, com $0,09 \%$ dos custos totais. 
O Ministério da Agricultura, Pecuária e Abastecimento (MAPA), publicou a portaria $\mathrm{n}^{\circ}$ 142 de 08/07/2015, que estabeleceu o preço mínimo de 12,05 (doze reais e cinco centavos) por quilo de castanha de baru da castanha (semente). Caso o agroextrativista venda seu produto abaixo desse valor, e comprove com notas fiscais, a Conab repassa a diferença diretamente aos agroextrativistas.

$\mathrm{O}$ valor estimado pela Conab divergiu do resultado encontrado nesse estudo para a safra de 2014. Mesmo que, estimado para safras diferentes, a discrepância dos valores são altas.

Infelizmente a metodologia e as variáveis técnicas adotadas não são divulgadas, mas provavelmente o estudo foi realizado para uma associação. Os custos são estimados no formato de painel, onde entidades, associações, sindicatos, ONG's, etc, são convidados a participar de uma reunião técnica, para definir os parâmetros e coeficientes que irão compor os custos fixos e variáveis.

\section{5 - RECEITAS}

As receitas médias obtidas foram de $\mathrm{R} \$ 2.616,44$ na safra 2013 e $\mathrm{R} \$ 2.180,00$ na safra 2014. Ao comparar as duas receitas, observou-se uma redução significativa na receita obtida no período avaliado (tabela 14).

Ao analisar a receita total em comparação com os dias de dedicação à atividade, nota-se que a safra 2014/2015 remunera $\mathrm{R} \$ 59,48$, enquanto o dia de trabalho do ano produtivo é de $\mathrm{R} \$ 44,52$, ou seja, em anos produtivos, ocorre um excesso na oferta e a consequente diminuição do preço, reduzindo a remuneração diária significativamente.

Tabela 15 - Análise comparativa dos custos nas diferentes safras em estudo.

\begin{tabular}{cccccc}
\hline Safra & $\begin{array}{c}\text { Preço médio } \\
(\mathbf{R} \mathbf{)}\end{array}$ & Produção & $\begin{array}{c}\text { Receita total } \\
(\mathbf{R} \mathbf{)}\end{array}$ & $\begin{array}{c}\text { Dias de } \\
\text { dedicação }\end{array}$ & $\begin{array}{c}\text { Receita diária } \\
(\mathbf{R} \mathbf{)})\end{array}$ \\
\hline $2013 / 2014$ & 14,55 & 180,35 & $2.648,10$ & 59,48 & 44,52 \\
$2014 / 2015$ & 20,92 & 104,27 & $2.180,00$ & 36,52 & 59,66 \\
\hline
\end{tabular}

Fonte: Dados de campo (2015).

Ao analisar as receitas líquidas não atualizadas, pode-se perceber claramente o efeito da volatilidade da produção na renda das famílias, em períodos de baixa produção como nos anos de 2014, a renda reduz drásticamente (figura 12). Esses valores foram obtidos 
utilizando os valores médios da safra e entresafra do ano de 2014, que foram deflacionados para os anos do horizonte de planejamento.

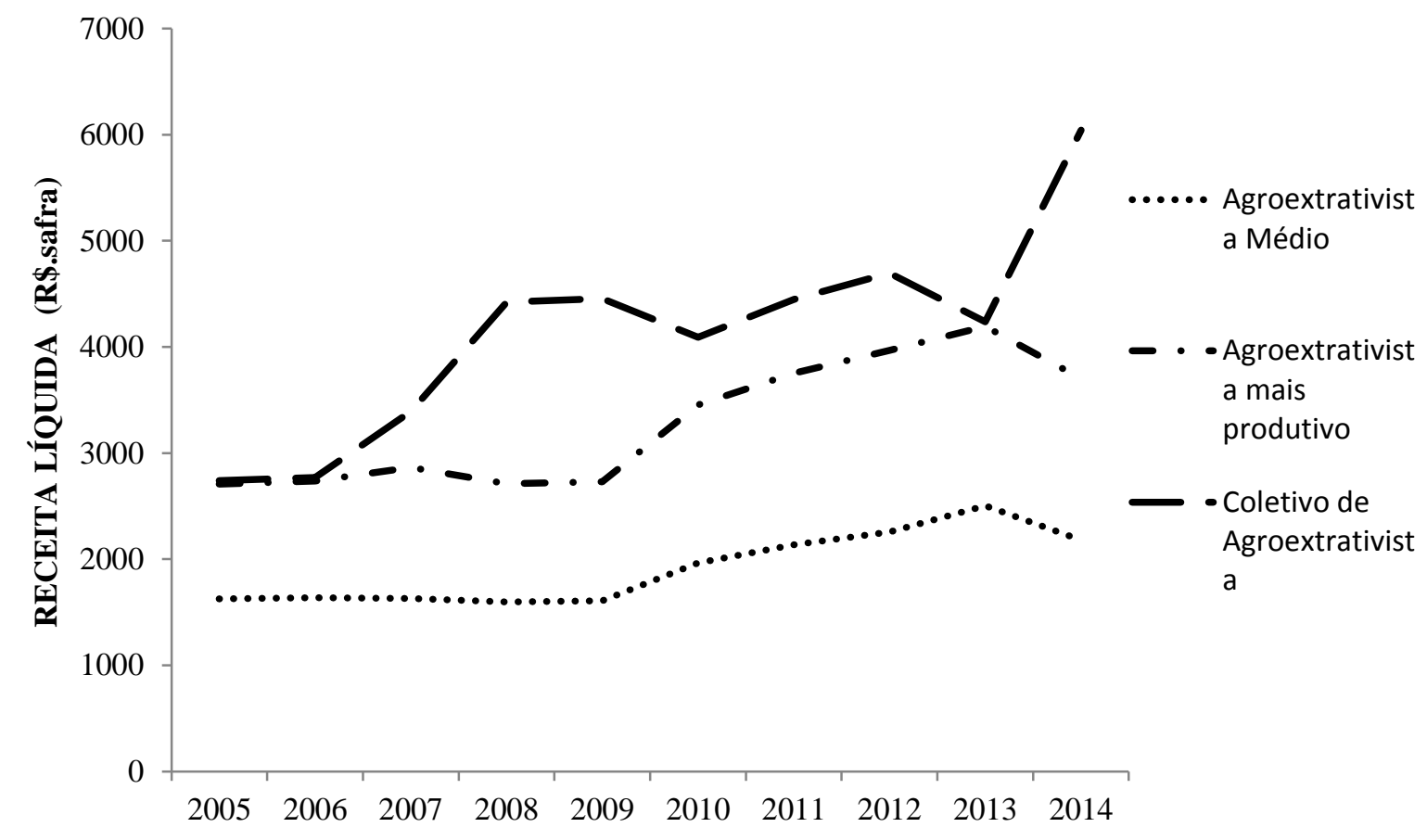

Figura 2 - Receita líquida dos projetos em análise

Fonte: Dados de campo (2015).

\section{6 - ANÁLISE ECONÔMICA E FINANCEIRA}

\subsubsection{Indicadores econômicos de rentabilidade}

Os resultados financeiros demonstram que o extrativismo do baru é viável economicamente em todos os indicadores de rentabilidade utilizados, com exceção dos agroextrativistas médios para a safra 2014/2015, que obtiveram a Receita Líquida negativa (tabela 15).

Esse indicador econômico foi afetado negativamente pela elevação do valor da mão de obra. Os demais indicadores econômicos dos agroextrativistas mais produtivos e da organização coletiva dos agroextrativistas de Sagarana, foram positivos em ambas as safras. 
Tabela 16 - Rentabilidade do extrativismo para a Safra 2013/2014.

\begin{tabular}{ccccc}
\hline $\begin{array}{c}\text { Indicador } \\
\text { econômico }\end{array}$ & Unidade & $\begin{array}{c}\text { Agroextrativista } \\
\text { médio }\end{array}$ & $\begin{array}{c}\text { Agroextrativista } \\
\text { mais produtivo }\end{array}$ & $\begin{array}{c}\text { Membro } \\
\text { coletivo }\end{array}$ \\
\hline $\mathrm{RTF}$ & $\mathrm{R} \$ / \mathrm{safra}^{-1}$ & $2.116,47$ & $3.439,41$ & 3855,73 \\
$\mathrm{RL}$ & $\mathrm{R} \$ \mathrm{safra}^{-1}$ & 186,58 & 380,40 & 807,22 \\
$\mathrm{RMOF}$ & $\mathrm{R} \$$ dia $^{-1}$ & 37,02 & 37,85 & 41,38 \\
$\mathrm{CUP}$ & $\mathrm{R} \$ / \mathrm{Kg}$ castanha & 13,26 & 13,22 & 12,99 \\
$\begin{array}{c}\text { Preço/ } \\
\text { agroextrativistas }\end{array}$ & $\mathrm{R} \$ / \mathrm{Kg}$ castanha & 15,31 & 15,46 & 16,76 \\
\hline
\end{tabular}

Fonte: Dados de campo (2015).

Onde:

$\mathrm{RTF}=$ Renda do trabalho familiar, R $\$ . \mathrm{Safra}^{-1}$;

$\mathrm{RL}=$ Receita líquida, $\mathrm{R} \$ . \mathrm{Safra}^{-1}$,

$\mathrm{RMOF}=$ Remuneração da mão de obra familiar; e

CUP= Custo Unitário de Produção, $\mathrm{R} \$ \mathrm{Kg}$ castanha.

Com o aumento da escala ocorreram melhorias nos indicadores de viabilidade econômica e financeira. Ao comparar a receita líquida de um membro do coletivo com o agroextrativista médio, percebe-se que ocorreu um aumento de 4,32 vezes em seu valor. Em relação aos mais produtivos esse aumento foi de 2,12 vezes.

As diferenças entre os agroextrativistas médios e o membro do coletivo de agroextrativistas são mais discrepantes na safra 2014/2015 (tabela 16). A receita líquida variou de valores negativos até valores superiores a $\mathrm{R} \$ 1.000,00$.

Tabela 17 - Rentabilidade do extrativismo para a Safra 2014/2015.

\begin{tabular}{ccccc}
\hline $\begin{array}{c}\text { Indicador } \\
\text { econômico }\end{array}$ & Unidade & $\begin{array}{c}\text { Agroextrativi } \\
\text { sta médio }\end{array}$ & $\begin{array}{c}\text { Agroextrativista } \\
\text { mais produtivo }\end{array}$ & $\begin{array}{c}\text { Membro } \\
\text { Coletivo }\end{array}$ \\
\hline $\mathrm{RTF}$ & $\mathrm{R} \$ \cdot \mathrm{dia}^{-1}$ & $1.520,20$ & $2.792,5$ & 5060,69 \\
$\mathrm{RL}$ & $\mathrm{R} \$ \cdot \mathrm{safra}^{-1}$ & $-0,42$ & 276,43 & $1.099,31$ \\
$\mathrm{RMOF}$ & $\mathrm{R} \$ . \mathrm{dia}^{-1}$ & 41,63 & 45,54 & 53,75 \\
$\mathrm{CUP}$ & $\mathrm{R} \$ \mathrm{Kg}$ & 19,41 & 17,94 & 17,20 \\
Preço ao & $\mathrm{R} \$ / \mathrm{Kg}$ & 20,92 & 20,82 & 22,50 \\
agroextrativistas & castanha & & &
\end{tabular}

Fonte: Dados de campo (2015).

Todos os perfis analisados remuneraram a mão de obra familiar (RMOF), ou seja, os valores diários recebidos superaram aos seus custos de oportunidade. Os valores do indicador de RMOF responderam positivamente ao ganho de escala. 
Estudos similares que utilizaram o indicador de RMOF foram desenvolvidos na Amazônia, em especial com a cadeia produtiva da castanha do Pará (SANTOS et al. 2002; SÁ, 2008; SILVA et al., 2013). Para fins de comparação desses estudos todos os valores foram atualizados (Tabela 17) usando o indexador IGP-DI, base (jul/2014).

Tabela 18 - Quadro comparativo dos resultados encontrados na literatura.

\begin{tabular}{|c|c|c|c|c|c|}
\hline $\begin{array}{l}\text { Indicador } \\
\text { econômico }\end{array}$ & Unidades & $\begin{array}{l}\text { SANTOS et } \\
\text { al. (2002) }\end{array}$ & $\begin{array}{l}\text { SÁ et al. } \\
\text { (2008) }\end{array}$ & $\begin{array}{l}\text { SILVA et } \\
\text { al. (2013) }\end{array}$ & $\begin{array}{c}\text { Agroextrativista } \\
\text { mais } \\
\text { produtivo } *^{1}\end{array}$ \\
\hline RL & R\$.safra & $1.143,21$ & 475,62 & 390,06 & 276,43 \\
\hline RMOF & $\mathrm{R} \$ . \mathrm{dia}^{-1}$ & 49,83 & 34,16 & 26,23 & 45,54 \\
\hline RTF & $\mathrm{R} \$ . \mathrm{dia}^{-1}$ & - & - & $2.570,74$ & $2.792,5$ \\
\hline Mão de obra & $\mathrm{R} \$ . \mathrm{dia}^{-1}$ & 26,70 & 27,33 & 26,02 & 40,00 \\
\hline Diferença & $\mathrm{R} \$ . \mathrm{dia}^{-1}$ & 23,13 & 6,83 & 0,21 & 5,54 \\
\hline
\end{tabular}

$*^{1}$ Fonte: Dados de campo (2015).

Analisando estudos similares, a RMOF foi superior para os extrativistas da castanha do Brasil de Almeirin/PA, que remunerou $\mathrm{R} \$ 23,13$ acima do valor da mão de obra local (SANTOS et al., 2002). No estado do Acre, na Reserva Extrativista Chico Mendes, em Brasiléia, a castanha do Brasil remunerou $\mathrm{R}$ \$ 6,83 acima da diária.

Essa análise tem caráter exemplificativo, existem limitações nas comparações do extrativismo praticado na Amazônia e no Cerrado. O valor da mão de obra e os modais de transportes adotados são diferentes, assim como outros custos de produção, dificultando uma comparação mais apropriada.

\subsubsection{Avaliação Financeira}

Ao analisar a viabilidade financeira de investimento na construção de um paiol, pelo método do valor presente líquido (VPL), foi observada a inviabilidade do investimento dos agroextrativistas médios e mais produtivos (tabela 18). Os valores, no horizonte de planejamento de 10 anos, tanto para o agroextrativista médio, como para o mais produtivo, foram negativos. Entretanto, ao analisar os membros do coletivo de agroextrativistas, o VPL mostrou-se positivo, indicando a viabilidade do empreendimento. 
Tabela 19 - Indicadores de viabilidade que variam o valor do capital no tempo.

\begin{tabular}{ccccc}
\hline $\begin{array}{c}\text { Indicador } \\
\text { econômico }\end{array}$ & Unidade & $\begin{array}{c}\text { Agroextrativista } \\
\text { médio }\end{array}$ & $\begin{array}{c}\text { Agroextrativista } \\
\text { mais produtivo }\end{array}$ & $\begin{array}{c}\text { Membro } \\
\text { Coletivo }\end{array}$ \\
\hline $\mathrm{VPL}_{10}$ & $\mathrm{R} \$ . \mathrm{safra}^{-1}$ & $-1.534,05$ & $-1.468,38$ & $5.705,62$ \\
$\mathrm{BPE}$ & $\mathrm{R} \$ \cdot \mathrm{ha}^{-1} \cdot \mathrm{ano}^{-1}$ & $-184,45$ & $-176,56$ & 686,05 \\
$\mathrm{CMPr}$ & $\mathrm{R} \$ . \mathrm{kg}^{-1}$ & 14,40 & 13,85 & 12,24 \\
Preço médio & $\mathrm{R} \$ . \mathrm{kg}^{-1}$ & 13,91 & 13,90 & 15,07 \\
\hline
\end{tabular}

Fonte: Dados de campo (2015).

Foi avaliada a capacidade de pagamento no investimento de um novo paiol, utilizado para armazenamento da produção. Dessa forma ocorreria um melhor controle do volume de comercialização no período de safra e entre safra, aproveitando os melhores preços.

Os custos médios de produção diminuíram com o aumento da escala de produção, demonstrando que esse indicador econômico responde positivamente ao ganho de escala. Os preços médios praticados, no horizonte de planejamento adotado, mantiveram-se praticamente inalterado entre os agroextrativistas médios e mais produtivos.

No entanto, o coletivo de agroextrativistas negociaram suas castanhas a valores significativamente maiores que os demais, principalmente porque na região produtiva em que se localizam os agroextrativistas coletivos, ocorre a venda direta aos consumidores.

Foi analisado o efeito de alterações nas variáveis quantidades e valor da mão de obra no valor presente líquido (VPL). Mesmo com a redução em 5\% da quantidade de mão de obra os empreendimentos individuais continuam inviáveis (figura 13, gráfico C), somente após a redução de $10 \%$ na quantidade de mão de obra é que o cenário se altera (gráfico D).

O projeto se viabiliza financeiramente com melhorias no processo produtivo do baru, principalmente pela maior eficiência no beneficiamento do fruto, ou diminuição do tempo dedicado à coleta, seja utilizando técnicas de cultivo racional, ou por melhoras na organização de rotas de coleta.

Outra variável analisada foi o aumento do valor da mão de obra. Ao considerar o custo de oportunidade no valor de $\mathrm{R} \$ 30,00$, referente ao preço da safra 2013/2014, todos os perfis 
obtiveram o VPL positivo, no entanto os agroextrativistas médios e mais produtivos conseguiram valores positivos a partir do segundo ano (gráfico a). Ao considerar o valor da mão de obra a $\mathrm{R} \$ 40,00$, preço da safra 2014/2015, os empreendimentos individuais tornaram-se inviáveis (item b) (figura 13). A volatilidade da produção influencia diretamente o fluxo de caixa, tornando-o negativo em anos de alta produção e preços baixos.

Essa volatilidade influencia diretamente o VPL, tornando-os negativos e comprometendo a viabilidade do investimento proposto. No entanto, em anos de baixa produção, mesmo com o aumento do esforço de coleta, o fluxo de caixa torna-se positivo, em especial pelo aumento do valor da castanha.

$\mathrm{O}$ agroextrativista individual que investiu na atividade, somente poderá resgatar o seu investimento, caso ocorra uma redução na quantidade de $10 \%$ na mão de obra e somente a partir do $5^{\circ}$ ano (2009), no caso do agroextrativista mais produtivo. No entanto, ao considerar o agroextrativista médio, o empreendimento continuaria inviável.

Essa diminuição do custo com a mão de obra poderá ocorrer com o uso de equipamentos mais eficientes, diminuição do tempo dedicado a viagens exclusivas para a comercialização e menor dedicação a atividade de coleta.

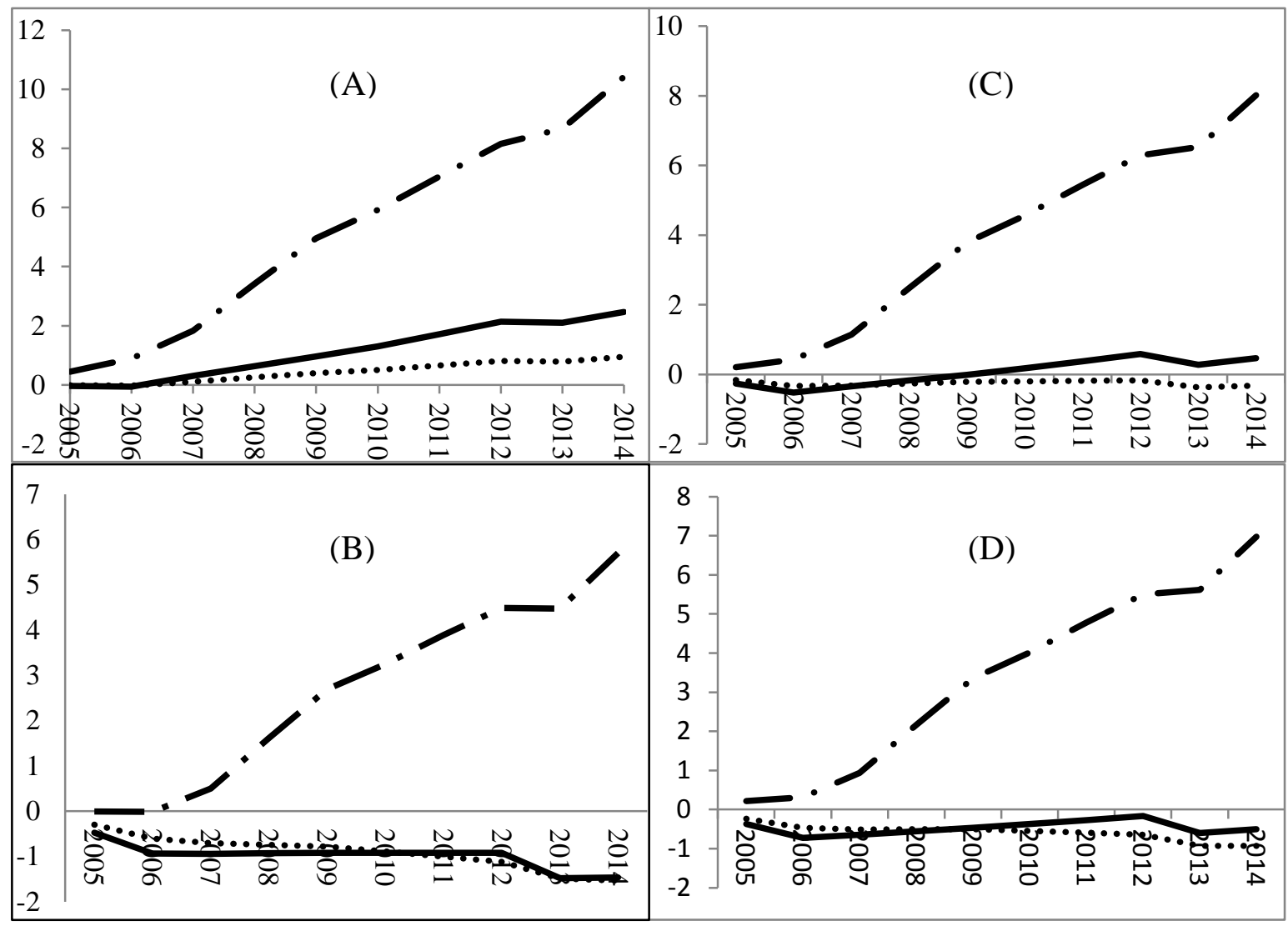


Fonte: Dados da pesquisa (2015).

- - - Membro do Coletivo de agroextrativistas

Mais produtivo

Médio

Figura 3 - Análise de comportamento do VPL.

Onde:

(A): Preço mão de obra a R \$ 30,00; (B): Preço mão de obra a R \$ 40,00; (C): Redução na mão de obra em 10\%; (D): Redução na mão de obra em 5\%.

A utilização de plantios racionais contribui para diminuir os custos de produção, como por exemplo, o tempo de dedicação à coleta, manutenções e depreciações. Esses cultivos não são conflitantes com a atividade extrativa e ocorreriam concomitantemente, ampliando as fontes de renda da família.

Considerando os resultados, o investimento somente seria viável economicamente, se os agroextrativistas organizassem e trabalhassem coletivamente, diminuindo os custos com transporte externo, galpões e o uso de materiais e equipamentos.

Esses valores obtidos corroboram com a realidade da maioria dos agricultores familiares, em especial os agroextrativistas. Pois existem dificuldades históricas no investimento de construção de benfeitorias. Dessa maneira os resultados demonstram a necessidade de criar novas políticas públicas para o setor e ampliando as já existentes, para a produção extrativista e agroecológica.

\section{4 - CONCLUSÕES E RECOMENDAÇÕES}

- Dentro dos projetos avaliados, todos remuneraram acima do custo de oportunidade, provando a importância do extrativismo na economia da agricultura familiar e na fixação do homem no campo.

- A escala afeta diretamente a viabilidade econômica e financeira de uma economia extrativista, na medida em que a produção aumenta ocorrem melhoras nos indicadores econômicos e financeiros. 
- A viabilidade de um investimento de médio e longo prazo fica comprometida, no caso dos agroextrativistas individuais, somente a organização coletiva se mostrou viável na taxa de desconto utilizada e no horizonte de planejamento adotado.

- Historicamente o agricultor familiar possui dificuldade em organizar a produção coletivamente, os empreendimentos da agricultura familiar possuem extremas dificuldades em se viabilizar economicamente.

- Políticas públicas de fomento, assistência técnica, social e ambiental para esse segmento da sociedade são importantes. Noções de empreendedorismo, associativismo, economia solidária, entre outros, devem ser adaptados a esse público alvo.

- O cultivo racional deve ser estimulado. Estudos acerca do crescimento, produtividade, comportamento silvicultural, modelos de consórcios, quintais agroflorestais, sistemas silvipastoris, plantios puros ou consorciados, devem ser testados. 


\section{REFERÊNCIAS BIBLIOGRÁFICAS}

ALBUQUERQUE, U. P.; LUCENA R. F. P.; LINS NETO E. M. F. Seleção dos participantes da pesquisa. In: Albuquerque, U. P.; Lucena R. F. P. Métodos e técnicas na pesquisa etnobiológica e etnoecológica. Recife: NUPEEA; 2010. p. 21-38.

ALVES, R. V. Estudo de caso da comercialização dos produtos florestais não madeireiros (PFNM) como subsídio para restauração florestal. 2010. 231 p. Dissertação (Mestrado em Ciência Florestal) - Universidade Federal de Viçosa, 2010.

BOMFIM, S. L. Viabilidade econômica e financeira de extração sustentada de múltiplos produtos em floresta estacional semidecídua secundária na microrregião do entorno de Brasília. 168 f. Dissertação (Mestrado em Ciências Florestais) - Universidade de Brasília, Brasília, 2010.

BOTEZELLI, L.; DAVIDE, A. C.; MALAVASI, M. M. Características dos frutos e sementes de quatro procedências de Dipteryx alata Vogel - (baru). Cerne, v. 6, n.1, p.9$18,2000$.

BRITO, M. A. de. Fitopatologia e ecologia de população de Dipterix lata Vog. (baru) em área de transição Cerrado Denso/Mata estacional, Pirenópolis, GO. 2004. 127p. Tese (Doutorado em ecologia) - Universidade de Brasília, Brasília.

CASTELO, C. E. F. Avaliação econômica da produção familiar na reserva extrativista Chico Mendes no estado do Acre. Caderno de Pesquisa em Administração, São Paulo, V.1, n. 11. 2000.

COELHO JUNIOR, L. M.; RESENDE, L. P.; OLIVEIRA, D.; COIMBRA, L. A. B., SOUZA, A. N. Análise de investimento de um sistema agroflorestal sob situação de risco. Cerne, Lavras, v. 14, n. 4, p. 368-378, 2008.

CONAB - COMPANHIA NACIONAL DE ABASTECIMENTO. Custos de Produção Agrícola: a metodologia da Conab. Brasília: Conab, 2010. Disponível em: http://www.conab.gov.br/conabweb/download/safra/custos.pdf. Acesso em: 20 novembro, 2015.

CONAB - COMPANHIA NACIONAL DE ABASTECIMENTO. Plano Operacional Anual de Apoio à Comercialização de Produtos da Sociobiodiversidade Safra 2014/16. Brasília, 2014.

DESLANDE, S. F.; GOMES, R.; MINAYO, M. C. S. Pesquisa social: teoria, método e criatividade. 34 ed. Petrópolis, RJ: Vozes, 2015. 108 p.

EASYCALC. EasyCalc- Cálculos financeiros e judiciais pela web. Disponível em: http://drcalc.net/correcao.asp?it=3\&ml=Calc. Acesso em: 01/01/2016

FERREIRA, D. F. SISVAR - Sistema de análise de variância para dados balanceados. Lavras: UFLA, 1999. 
FIEDLER, N. C.; SOARES, T. S.; SILVA, G. F. da. Produtos Florestais Não Madeireiros: Importância e Manejo Sustentável da Floresta. Revista Ciências Exatas e Naturais, vol. 10 n.2, p.16, 2008.

GIL, A. C. Métodos e Técnicas de Pesquisa Social. 6.ed. São Paulo: Atlas, 2009.

GODOY, R. A.; BAWA, K. S. The economic value and sustainable harvest of plants and animals from the tropical forest: assumptions, hypotheses, and methods. Economic Botany V. 47, n.3, 1993. p.220-233.

GODOY, R. A.; LUBOWSKI.; MARKANDYA, A. A method for the economic valuation of non-timber tropical forest products. Economic Botany, Ney York, v. 47, n.3, 1993. p.215-219.

GRZEBIELUCKAS, G. A Influência dos custos ambientais externos na produção agrícola: estudo comparativo entre frutos do cerrado e pecuária leiteira. Tese de Doutorado do Programa de Pós-Graduação em Engenharia de Produção, Universidade Federal de Santa Catarina, Florianópolis, SC, 2010.

IBGE. Instituto Brasileiro de Geografia e Estatística- IBGE. Disponível em:<ftp://ftp.ibge.gov.br/Censos/Censo_Agropecuario_2006/agri_familiar_2006>. Acesso em: 01 abril de 2014.

IBGE - INSTITUTO BRASILEIRO DE GEOGRAFIA E ESTATÍSTICA. Produção da Extração Vegetal e da Silvicultura - PEVS 2014. Rio de Janeiro, v. 29, 2014.

LEITE, M.A., PEREIRA, J.C., YANO, E.H.1, ZOCOLER, J.L., HERNANDEZ, F.B.T. Projetos de Construções em pequenas propriedades rurais. In: XLIII Congresso Brasileiro de Engenharia Agrícola, Anais. CIDADE: CONBEA, 2014. CD-ROM.

MENDES, J.T.G. Economia agricola; principios basicos e aplicacoes. Curitiba, PR (Brazil). 1989. Scientia et Labor. 399 p

MENEZES, R.S. de. A importância da reserva legal na geração de renda de pequenos produtores rurais: estudo de caso no estado do Acre, Amazônia. 105 f. Dissertação (Mestrado em Ciências Florestais) - Universidade Federal do Paraná, Curitiba, 2004.

NEUMANN, R. P.; HIRSCH, E. Commercialisation of non-timber forest products: review and analysis of research. Center for International Forestry Research, Bogor, Indonesia, 2000.

NOGUEIRA, M; FLEISCHER, S. Entre tradição e modernidade: potenciais e contradições da cadeia produtiva agroextrativista no Cerrado. Estudos Sociedade e Agricultura. Rio de Janeiro: CPDA-UFRRJ, v. 13, n. 1, p. 125-157, 2005.

PETERS, C.M.; GENTRY, A.H.; MENDELSOHN, R.O. Valuation of na Amazonian rainforest. Nature, v. 339, p. 655-656, 1989. 
PNUD. Programa das Nações Unidas para o Desenvolvimento. Atlas do Desenvolvimento Humano no Brasil 2013. Disponível em: 〈http://atlasbrasil.org.br/2013/perfil/arinos_mg>. 01 abril de 2014.

QUARESMA, J., BONI, V. Aprendendo a entrevistar: como fazer entrevistas em Ciências Sociais. Em Tese, v. 2, nº 1, p. 68-80, 2005.

RÊGO, L. J. S. Análise econômica da produção da amêndoa de cumaru e caracterização do seu mercado em Santarém e Alenquer, Pará. 105 f. Dissertação (Mestrado em Ciências Florestais) - Universidade Federal de Viçosa, Viçosa, 2014.

REZENDE, J. L. P.; OLIVEIRA, A. D. Análise econômica e social de projetos florestais. Viçosa, MG: UFV, 2013. 384 p.

SÁ, C. P.; BAYMA, M. M. A.; WADT, L. H. O. Coeficientes técnicos, custo e rentabilidade para a coleta de castanha-do-brasil no estado do Acre: sistema de produção melhorado. Rio Branco: Embrapa Acre, Comunicado Técnico, n. 168. 2008. 4 p.

SANTOS, J. C. dos; SÁ, C. P. de; ARAÚJO, H. J. B. de. Aspectos financeiros e institucionais do manejo florestal madeireiro de baixo impacto em áreas de reservas legal de pequenas propriedades, na Amazônia. In: CONGRESSO BRASILEIRO DE ECONOMIA E SOCIOLOGIA RURAL, 37., 1999, Foz do Iguaçu. O agronegócio do Mercosul e a sua inserção na economia mundial: anais. Brasília, DF: Sociedade Brasileira de Economia e Sociologia Rural, 1999. p. 158. Resumo.

SANTOS, J.C. dos; VEIGA, S.A.; SÁ, C.P. de; WADT, L.H. de O.; Nascimento, G.C. do; Silva, M.R. da. Estimativa de custo de coleta e rentabilidade para sistema extrativo de castanha-do-Brasil no Acre, safra 2001/2002. Embrapa Acre. Comunicado Técnico, $\mathrm{n}^{\mathrm{o}}$ 156, 2002. 4p.

SANTOS, A. J; HILDEBRAND, E; PACHECO, C.H.P; PIRES, PT de Le ROCHADELLI, R. et al. Produtos não madeireiros: Conceituação, classificação, valoração e mercados. Curitiba, 14 p. Floresta, Curitiba, 2005.

SANO, S. M.; SIMON, M. F. Produtividade de Baru (Dipteryx alata Vog.) em Ambientes Modificados, Durante 10 Anos. In: IX Simpósio Nacional Cerrado. II Simpósio Internacional Savanas Tropicais. ParlaMundi, Brasília, DF, 2008.

SCOLFORO, J. R.; CARVALHO, L. M. T. de. Mapeamento e inventário da flora nativa e dos reflorestamentos de Minas Gerais. Lavras: Editora UFLA, 2006. 288 p.

SCOLFORO, J. R.; OLIVEIRA, A. D.; CARVALHO, L. M. T. de; MARQUES, J. J. G.; LOUZADA, J. N.; MELlO, C. R.; PEREIRA, J. R.; REZENDE, J. B.; VALE, L. C. C.. Zoneamento ecológico-econômico de Minas Gerais. In: SCOLFORO, J. R.; OLIVEIRA, A. D.; CARVALHO, L. M. T. (Ed.). Zoneamento ecológico-econômico do Estado de Minas Gerais: zoneamento e cenários exploratórios. Lavras: UFLA, 2008. Cap. 1, p. 7 20 .

SILVA, M. L.; JACOVINE, L. A.; VALVERDE, S. R. Economia florestal. 2. ed. Viçosa: UFV, 2008. $178 \mathrm{p}$. 
SILVA, P.S. Análise econômica e sócioambiental da produção extrativista de frutos de cerrado: O caso da Cooperfruto, Tocantins. Dissertação (Mestrado em Desenvolvimento Regional e Agronegócio) - Universidade Federal do Tocantins, Palmas, Tocantins, 148 p., 2011.

SILVA, A. S.; SANTOS, M. K. V.; GAMA, J. R. V.; NOCE, R. LEÃO, S. Potencial do Extrativismo da Castanha-do-Pará na Geração de Renda em Comunidades da Mesorregião Baixo Amazonas, Pará. Floresta e Ambiente, v. 20, n. 4, 2013.

SALGANIK, M. J.; HECKATHORN, D. D. Sampling and estimation in hidden population using respondente-driven sampling. Sociological Methodology. V. 34, p. 193-240, 2004.

SCHNEIDER S. A pluriatividade na agricultura familiar. Porto Alegre: Ed. UFRGS; 2003. $253 \mathrm{p}$.

TAKEMOTO, E.; OKADA, I.A.; GARBELOTTI, M.L.; TAVARES M.; AUEDPIMENTEL, S. Composição química da semente e do óleo de baru (Dipteryx alata Vog.) nativo do Município de Pirenópolis, Estado de Goiás. Revista do Instituto Adolfo Lutz, 60 (2001), pp. 113-117.

UNIVERSIDADE FEDERAL DE LAVRAS. Sistema do Inventário Florestal da Flora Nativa e dos Reflorestamentos de Minas Gerais. Disponível em: < http://www.inventarioflorestal.mg.gov.br/>. Acesso em: 25 jun. 2015.

VASCONCELOS, M.A.S.; GARCIA, M.E. Fundamentos da Economia. $5^{\text {a }}$ ed. São Paulo: Saraiva 2014. 


\section{CAPÍTULO 2}

\section{O MERCADO DA CASTANHA DE BARU (Dipteryx alata VOGEL.) NA MESORREGIÃO DO NOROESTE DE MINAS GERAIS}

\section{RESUMO}

A comercialização dos PFNMs promove a valorização do bioma Cerrado e proporciona uma fonte de renda significativa para as famílias agroextrativistas. Este capítulo tem como objetivo analisar o mercado do baru (Dipteryx alata VOGEL.) na mesorregião do Noroeste de Minas Gerais, caracterizando sua cadeia produtiva, rendimentos operacionais e comercialização, construindo seu fluxograma e auferindo as margens e markups de comercialização. Foram realizadas entrevistas com diversos agentes da cadeia produtiva e sua atuação no canal de comercialização. Também foram entrevistados entidades e órgãos públicos que regulam, estimulam e contribuem com a comercialização do baru. Os resultados demonstram que a renda proporcionada pela venda do baru totaliza um valor diário de $\mathrm{R} \$ 50,96$, referentes a 42,94 dias de trabalho. Esses valores demonstram a importância do baru como uma renda complementar para as famílias. Ao estudar as margens de comercialização, foi observado que os agroextrativistas não se apropriam do valor de venda final ou em relação ao seu custo de produção. Ou seja, esse valor evidencia a importância de agregação de valor à castanha do baru e da venda direta ao consumidor, auferindo maiores margens de comercialização aos agroextrativistas.

Palavras-chave: Uso sustentável, extrativismo, produto florestal não madeireiro, margens de comercialização. 


\title{
The baru nuts (Dipteryx alata Vogel.) market in the Northwerstern Minas Gerais mesoregion
}

\begin{abstract}
The marketing of non timber forest products promotes the appreciation of the Cerrado and provides a significant income source for the agroextractivist farmers involved. This chapter aims to analyze the Baru (Dipteryx alata Vogel.) nuts market in the mesoregion of the Northwest of Minas Gerais State, featuring its production chain, operating income and marketing by building its flow chart and inferring trade margins and markups. Interviews with various Baru production chain players and their performance in the sales channel were carried out. Public bodies and organizations which regulate, foster and contribute to the commercialization of Baru nuts were also interviewed. The results show that the income provided by the sales of nuts amounts to a daily value of $\mathrm{R} \$ 50.96$, relating to 42.94 days of work. These figures demonstrate the importance of the Baru nuts as supplementary income for the families. By studying trade margins, it was observed that agroextractivist farmers do not appropriate the final sale value or the one related to its production cost. This figure highlights the importance of adding value to baru nuts and the direct sales to final consumers, providing greater trade margins to the farmers.
\end{abstract}

Keywords: Sustainable use, extraction, non-timber forest product sales margins. 


\section{1- INTRODUÇÃO}

A comercialização de Produtos Florestais Não Madeireiros (PFNMs) oriundos do extrativismo em áreas de vegetação nativa, plantadas ou de sistemas agroflorestais, pode proporcionar o desenvolvimento socioeconômico das famílias responsáveis pela sua extração e venda, da cidade ou da região que comercializa, além de satisfazer a necessidade do consumidor e contribuir para a conservação dos recursos naturais (RÊGO, 2014).

O comércio de PFNMs é apontado como uma ferramenta de conservação da floresta e melhoria na renda dos agroextrativistas (KAR e JACOBSON, 2011), contribuindo na diminuição da pobreza das populações dos trópicos (TAPIA e CHILPA, 2008).

Diversas iniciativas estão sendo estimuladas para uso sustentável dos recursos naturais, entre elas estão à comercialização dos PFNMs. Os mercados locais para PFNM, onde as espécies vegetais nativas do Cerrado estão incluídas, tendem ainda a ser relativamente pouco reconhecidos, subestimados e negligenciados. Além disso, não existem informações detalhadas sobre a magnitude da grande maioria das espécies, pois sua estrutura local é bastante espalhada e os dados estatísticos pouco confiáveis (SHACKLETON et al., 2007).

Estudos atuais com PFNMs mostram que muitas melhorias de ordem tecnológica precisam ser adotadas. Ao estudar os obstáculos à comercialização do baru, Magalhães (2014) apontou que as cooperativas que operam com produtos derivados de espécies vegetais nativas do Cerrado enfrentam dificuldades para viabilizar essa forma de produção. Além de um marco regulatório bastante confuso e incompleto, sofrem com a falta de informações sobre o comportamento do mercado, com a falta de domínio das etapas de processamento e beneficiamento do produto.

Outros fatores limitantes à economia destes produtos é a sazonalidade e a volatilidade da produção provocando oscilações na oferta, fragmentando as relações comerciais (ALMEIDA et al., 2012; MAGALHÃES, 2014). Outros fatores são a extração predatória, falta de cuidados com manuseio, dificuldade de organização por parte dos produtores; preço de mercado mais baixo que o custo de produção (ALMEIDA et al., 2012). 
O baru (Dipteryx alata Vogel) é uma espécie arbórea que ocorre no Brasil Central, principalmente em Minas Gerais, Goiás, Distrito Federal, Mato Grosso e Mato Grosso do Sul e é valorizada por suas diversas utilizações. É classificada botanicamente como um membro da família fabaceae (FERNANDES et al.; 2015), grande fixadora de nitrogênio no solo, ocorrendo em solos considerados mais férteis, entre aqueles dos cerrados, cerradões e matas (ARAKAKI et al., 2009).

A Política de garantia de Preços Mínimos dos Produtos de Sociobiodiversidade (PGPMBio) é resultado do plano nacional de promoção das cadeias de produtos da sociobiodiversidade, que estabeleceu um dos eixos de ação a promoção e apoio à produção e ao extrativismo sustentável, com o objetivo de fortalecimento e ampliação do acesso aos mercados (MMA et al., 2009).

O objetivo desse capítulo foi analisar o mercado do baru na mesorregião do Noroeste de Minas Gerais, caracterizando o canal de comercialização, construindo seu fluxograma e aferindo suas Margens e Markups de comercialização.

\section{2 - MATERIAIS E MÉTODOS}

A pesquisa foi realizada nos meses de maio e junho de 2014. As informações são referentes à safra de 2013, todos os valores foram corrigidos monetariamente e atualizados pelo Índice Geral de Preços- Disponibilidade Interna (IGP-DI), os valores foram corrigidos para setembro de 2015 .

Os dados foram obtidos utilizando entrevistas semiestruturadas com os integrantes da cadeia produtiva do baru na mesorregião do Noroeste de Minas Gerais e em Brasília-DF, principal destino da produção do baru.

\section{2 - CARACTERIZAÇÃO DA ÁREA DE ESTUDO}


As informações dos volumes comercializados, número de famílias, preços praticados pelos agroextrativistas cooperados, foram fornecidas pela cooperativa COPABASE, que adquire castanhas de toda a mesorregião do Noroeste de Minas.

Foi analisada a comercialização do baru dos diferentes elos da cadeia produtiva como agroextrativistas, intermediários, cooperativas, atacadistas e varejistas na região produtora. O mercado consumidor de Brasília é o principal destino das castanhas da região, onde diversas feiras livres, feiras permanentes, casas de dieta natural foram visitadas e os responsáveis entrevistados.

\section{3 - COLETA E ANÁLISE DOS DADOS}

Essa pesquisa é classificada como exploratória (GIL, 2008) e foi desenvolvida com o objetivo de proporcionar visão geral, de tipo aproximativo, acerca de determinado fato.

Para a coleta de dados foram utilizados questionários aplicados por meio de entrevistas semiestruturadas, que consiste numa técnica de pesquisa que combina perguntas abertas e fechadas, conforme detalhado no capítulo 1 .

A pesquisa foi realizada nos meses de maio e junho de 2014, as informações são referentes à safra de 2013, todos os valores foram corrigidos monetariamente e atualizados pelo Índice Geral de Preços- Disponibilidade Interna (IGP-DI). Os valores foram corrigidos para setembro de 2015 .

As correções dos valores estimados foram realizadas pelo aplicativo Calculadora do Cidadão do Banco Central do Brasil, esse aplicativo é disponibilizado na rede mundial de computadores no sítio eletrônico do $\mathrm{BCB}$, permitindo realizar correções de valores por diferentes índices de preço (BRASIL, 2016).

Os dados referentes aos custos de produção da atividade extrativista foram obtidos utilizando entrevistas semiestruturadas e apresentadas no Capítulo 1 (ANEXO I). Foram coletados os preços de aquisição e venda de todos os integrantes da cadeia produtiva, em especial os agroextrativistas, intermediários, cooperativas, atacadistas e varejistas. Foram 
entrevistados trinta e oito (38) agroextrativistas, três (3) cooperativas, três (3) intermediários, três (3) atacadistas e seis (6) varejistas, totalizando 53 entrevistas.

Para a coleta de dados dos feirantes, atacadistas, intermediários, varejistas entre outros integrantes, foi adotado a técnica da entrevista semiestruturada (Anexo II). Foram entrevistadas instituições públicas e entidades do terceiro setor que desenvolvem atividades afetas à comercialização do baru, em especial técnicos da Companhia Nacional de Abastecimento (CONAB), a organização Central do Cerrado e representantes da Cooperativa da Agricultura Familiar Sustentável com Base na Economia Solidaria (COPABASE).

Para a análise dos dados utilizou-se da estatística descritiva. São recursos que proporcionam caracterizar o que é típico no grupo e como os indivíduos se distribuem em relação a determinadas variáveis (GIL, 2008). Para a tabulação dos dados foram utilizadas planilhas eletrônicas, sistematizando as informações obtidas por meio da aplicação das entrevistas.

Foi possível identificar os principais integrantes da cadeia de comercialização e os respectivos canais de comercialização do baru, definindo preços praticados e os custos envolvidos nas etapas de coleta e pré-beneficiamento do baru no vale do Urucuia.

\section{4 - MARGENS DE COMERCIALIZAÇÃO}

A Margem $(\mathrm{Mb})$ de comercialização refere-se à diferença entre preços a diferentes níveis do sistema de comercialização. A margem total (Mt) é a diferença entre o preço pago pelo consumidor e o preço recebido pelo produtor (tabela 01).

Esse conceito pode ser abordado de diversas formas, dependendo dos objetivos que se quer atender, pois cada produto tem formas de mercados e valores diferentes (MENDES e PADILHA JÚNIOR, 2007). 
Tabela 01- Fórmulas usadas no cálculo da margem de comercialização (Mb) .

\begin{tabular}{ccc}
\hline Categorias & Valor absoluto & Valor relativo \\
\hline Total $(\mathrm{Mt})$ & $\mathrm{Pv}-\mathrm{Pp}$ & {$[(\mathrm{Pv}-\mathrm{Pp}) / \mathrm{Pv}] \times 100$} \\
Agroextrativista $(\mathrm{Mp})$ & $\mathrm{Pp}-\mathrm{Cp}$ & {$[(\mathrm{Pp}-\mathrm{Cp}) / \mathrm{Pv}] \times 100$} \\
Cooperativa/Intermediário $(\mathrm{Mi})$ & $\mathrm{Pi}-\mathrm{Pp}$ & {$[(\mathrm{Pi}-\mathrm{Pp}) / \mathrm{Pv}] \times 100$} \\
Atacado $(\mathrm{Ma})$ & $\mathrm{Pa}-\mathrm{Pi}$ & {$[(\mathrm{Pa}-\mathrm{Pi}) / \mathrm{Pv}] \times 100$} \\
Varejo $(\mathrm{Mv})$ & $\mathrm{Pv}-\mathrm{Pa}$ & {$[(\mathrm{Pv}-\mathrm{Pa}) / \mathrm{Pv}] \times 100$} \\
\hline
\end{tabular}

Fonte: Adaptado de Mendes e Padilha Júnior (2007).

Onde:

$\mathrm{Cp}=$ Custo de produção do agroextrativista

$\mathrm{Pp}=$ preço em nível de produtor, preço de venda ao intermediário

$\mathrm{Pi}=$ preço em nível de intermediário, preço de venda ao atacado

$\mathrm{Pa}=$ preço em nível de atacadista, preço de venda ao varejo

$\mathrm{Pv}=$ preço em nível de varejo, preço pago pelo consumidor

O Markup de comercialização (Mk) analisa as diferenças de ganho entre os integrantes da cadeia produtiva, é definido como a diferença entre o preço de venda e o preço de compra (ou de custo).

Em termos absolutos, markup é igual à margem de comercialização, mas em termos relativos mostra o percentual de aumento entre os preços de venda e de compra relativamente ao preço de compra, ou entre o preço de venda e o custo de produção relativamente ao custo de produção (MENDES e PADILHA JÚNIOR, 2007). A tabela 02 apresenta as fórmulas para cálculo do markup de comercialização.

Tabela 02 - Fórmulas usadas no cálculo do markup (Mk).

\begin{tabular}{ccc}
\hline Categorias & Valor absoluto & Valor relativo \\
\hline Total $(\mathrm{Mt})$ & $\mathrm{Pv}-\mathrm{Pp}$ & {$[(\mathrm{Pv}-\mathrm{Pp}) / \mathrm{Pp}] \times 100$} \\
Agroextrativista $(\mathrm{Mc})$ & $\mathrm{Pp}-\mathrm{Cp}$ & {$[(\mathrm{Pp}-\mathrm{Cp}) / \mathrm{Cp}] \times 100$} \\
Cooperativa/Intermediário $(\mathrm{Mi})$ & $\mathrm{Pi}-\mathrm{Pp}$ & {$[(\mathrm{Pi}-\mathrm{Pp}) / \mathrm{Pp}] \times 100$} \\
Atacado $(\mathrm{Ma})$ & $\mathrm{Pa}-\mathrm{Pi}$ & {$[(\mathrm{Pa}-\mathrm{Pi}) / \mathrm{Pi}] \times 100$} \\
Varejo $(\mathrm{Mv})$ & $\mathrm{Pv}-\mathrm{Pa}$ & {$[(\mathrm{Pv}-\mathrm{Pa}) / \mathrm{Pa}] \times 100$} \\
\hline
\end{tabular}

Fonte: Adaptado de Mendes e Padilha Júnior (2007). 


\section{3 - RESULTADOS E DISCUSSÃO}

\section{1 - RENDIMENTOS OPERACIONAIS E CADEIA PRODUTIVA}

Inicialmente a comercialização na região de estudo, foi incentivada por uma agência de desenvolvimento sustentável, a Agência de Desenvolvimento Integrado e Sustentável do Vale do Rio Urucuia/ADSVRU, que contou com o apoio e recursos externos de agências de fomento à projetos de desenvolvimento sustentável, no caso a Fundação Banco do Brasil. Posteriormente foi criada a Cooperativa da Agricultura Familiar Sustentável com Base na Economia Solidaria (COPABASE).

A coleta geralmente é feita por agricultores familiares, que também realizam o beneficiamento dos frutos. Esses agricultores em sua maioria são assentados de reforma agrária e pequenos agricultores, que desenvolvem outras atividades agropecuárias, por isso são denominados por alguns autores como agroextrativistas.

A atividade de coleta dos frutos é extenuante, consequência da frequência de agachamentos e as longas distâncias percorridas com grande volume e peso. O transporte até as propriedades é realizado por carroças, carros e bicicletas e eventualmente contrata-se um transporte para buscar volumes maiores.

A ferramenta utilizada para o pré-beneficiamento do fruto é um machado, facão ou foice, adaptados sob uma base de madeira, com o qual se quebra o endocarpo lenhoso e extrai-se a semente. Outro equipamento muito utilizado para o mesmo fim é uma adaptação da foice de ferro convencional, fixada a uma base do mesmo material.

A atividade de beneficiamento é desenvolvida pelos agroextrativistas, sendo executada ao longo de vários dias, após o horário do trabalho, nos finais de semana e eventualmente se dedicam integralmente. Essa atividade é variável e ocorre conforme a necessidade financeira ou encomendas, tornando a estimativa do custo de produção variável e imprecisa. O rendimento da quebra do baru é variável conforme a experiência do agroextrativista e a manutenção dos equipamentos de processamento. 
Os agroextrativistas vendem as sementes (castanhas) cruas, pré-beneficiadas, destinando a uma cooperativa localizada no município de Arinos ou para os intermediários que atuam na região, raramente vendem diretamente ao consumidor. O período da safra inicia-se em agosto e se estende até novembro, período que normalmente não praticam a agricultura.

Raramente ocorre à venda direta do agroextrativista ao consumidor. Essa venda, quando ocorre, é feita a residência dos próprios agroextrativistas. A maior parte da produção é direcionada aos atacadistas de Brasília, principal destino do baru comercializado na região de estudo.

Os produtos da Cooperativa possuem rotulagem que permite a venda direta ao varejo, e ao consumidor, principalmente participando de feiras e eventos, que permitem a comercialização de produtos da sociobiodiversidade (figura 01). A organização Central do Cerrado, em parceria com a COPABASE, oferta castanhas de baru para mercados de alta gastronomia, recepções e coffe-breaks, além de coquetéis e lanches que são preparados a partir dos produtos ecossociais do Cerrado.

Outra atuação importante da organização Central do Cerrado é o comércio pela rede mundial de computadores, disponibilizando produtos da sociobiodiversidade produzidos por organizações dos agricultores familiares de diversas regiões do Cerrado e da Caatinga.

Essa estratégia é importante para ampliar o mercado consumidor das castanhas de baru, atendendo o interesse de consumidores, que normalmente não comprariam nos canais de comercialização convencionais da região de estudo.

Os atacadistas compram a semente de baru crua ou torrada dos intermediários ou da cooperativa, que são repassados ao varejo. Os maiores atacadistas possuem canais próprios de venda, podendo vender diretamente ao consumidor as sementes adquiridas.

A cooperativa comercializou um volume de 5.224,24 quilos de castanha no ano de 2013, sendo que participaram dessa atividade 35 famílias, o que equivale 149,26 quilos de frutos por família, correspondendo a uma produção de 61,18 sacos por família, que coletam em média 6,40 sacos de $60 \mathrm{Kg}$ de frutos por dia. 


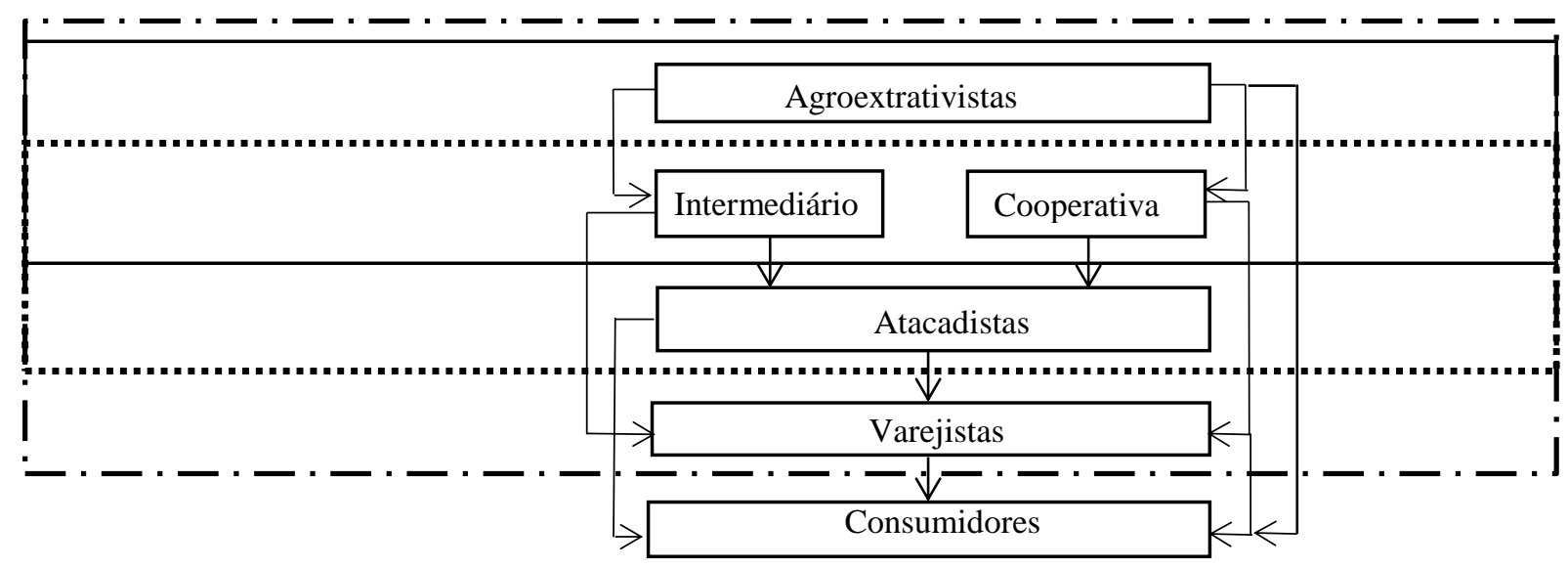

Figura 4 - Fluxograma da cadeia produtiva do baru na região de estudo.

Em que:

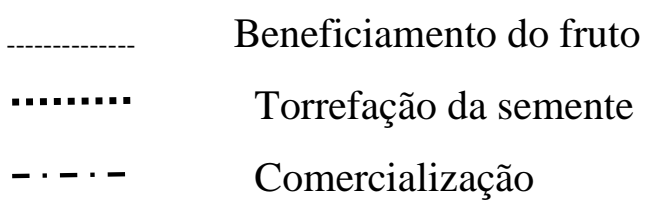

Quanto à etapa do beneficiamento do fruto as famílias envolvidas produziram 4,47 quilos de castanhas selecionadas por dia, que somaria uma dedicação ao beneficiamento de 33,39 dias.

Caso fossem comercializados somente os frutos, não passando pela etapa de prébeneficiamento, as famílias envolvidas obteriam uma renda de $\mathrm{R} \$ 827,76$, pois regionalmente vendem-se sacos de 60 quilos a $\mathrm{R} \$ 13,53$. Considerando a produção e o rendimento da coleta as famílias dedicariam aproximadamente 9,55 dias de trabalho para a atividade, que equivale a uma renda diária de $\mathrm{R} \$ 86,67$ por dia de trabalho.

Caso as famílias beneficiassem dos frutos, as famílias se dedicariam 33,39 dias à atividade, que somada ao tempo dedicado à coleta, totaliza uma dedicação de 42,94 dias para produção da castanha (tabela 3). As castanhas cruas foram comercializadas ao preço de $\mathrm{R} \$$ 14,66 o quilo, somando uma renda média de $\mathrm{R} \$ 2.188,33$ por família, que equivale a $\mathrm{R} \$$ 50,96 o dia de trabalho. 
Tabela 3 - Valor recebido por dia de trabalho.

\begin{tabular}{ccccc}
\hline $\begin{array}{c}\text { Valor médio recebido } \\
\text { (R\$) }\end{array}$ & Produção & $\begin{array}{c}\text { Renda total } \\
(\mathbf{R} \$)\end{array}$ & $\begin{array}{c}\text { Dias de } \\
\text { dedicação }\end{array}$ & $\begin{array}{c}\text { Valor /dia } \\
\text { trabalho }(\mathbf{R} \$)\end{array}$ \\
\hline $14,66 / \mathrm{kg} /$ semente $^{* 1}$ & 149,26 & 2188,33 & 42,94 & 50,96 \\
$13,53 / \mathrm{saco} 60 \mathrm{~kg} /$ fruto $^{* 2}$ & 61,18 & 827,76 & 9,55 & 86,67 \\
\hline
\end{tabular}

${ }^{*}$ COPABASE (2013), ${ }^{2}$ Dados de Campo (2014).

Esses valores consideram que o agroextrativista dedica-se exclusivamente a atividade do extrativismo, exercendo as atividades de coleta e quebra dos frutos durante 6 horas ao dia, intercalando com horários de descanso. Entretanto, essa situação é hipotética, pois na prática eles desenvolvem atividades agropecuárias e rotineiras dentro da propriedade rural concomitantemente ao processo produtivo do baru.

A característica de complementariedade de renda reforça a importância de manter as características de pluriatividade da agricultura familiar, conforme Bispo e Diniz (2014), onde a diversificação da produção aumenta a sustentabilidade da agricultura familiar. É importante salientar que o extrativismo proporciona maior autonomia no trabalho, pois as famílias organizam suas próprias rotinas de coleta e beneficiamento do fruto.

Observa-se que o processo de beneficiamento do fruto é rudimentar e pouco produtivo, sendo determinante nos custos de produção. Essa característica reforça a importância de inovações na cadeia produtiva, onde melhorias nos coeficientes técnicos do beneficiamento do fruto diminuem os custos de produção, consequentemente melhorando a renda das famílias.

A participação da semente de baru na economia municipal é baixa, não contribuindo significativamente para o Produto Interno Bruto, principalmente pela informalidade da atividade, proporcionada pela atuação dos intermediários. Porém, para os extrativistas, essa participação representa um incremento de renda importante nas famílias, em especial num período de baixa atividade agropecuária na região ocasionada pelos longos períodos de estiagem.

\section{2 - MARGEM E “MARKUP” DE COMERCIALIZAÇÃO}


Qualquer produto segue um caminho da sua produção até o consumidor final, sendo que esse caminho é definido como canal de comercialização. Ao analisar os valores de compra e venda entre os diferentes elos do canal de comercialização foi possível definir a margem bruta e markup de comercialização, da cadeia produtiva da castanha de baru na mesorregião do Noroeste de Minas Gerais.

$\mathrm{O}$ custo de produção dos agroextrativistas médios foi estimado em $\mathrm{R} \$ 12,60$ para os valores de 2013 e R\$ 14,50 em valores atualizados, para os agroextrativistas não cooperados. O custo de produção dos cooperados foi estimado em $\mathrm{R} \$ 13,11$, que corrigidos somam $\mathrm{R} \$ 15,09$, essa diferença corresponde ao custo da taxa anual da cooperativa.

O valor remunerado pela COPABASE foi de $\mathrm{R} \$ 13,00$ para agroextrativistas não cooperados e R\$14,00 para os cooperados, que corrigidos, corresponde a $\mathrm{R} \$ 14,96$ e $\mathrm{R} \$$ 16,11 respectivamente.

Os agroextrativistas não cooperados apropriaram cerca de $\mathrm{R} \$ 0,40$ por quilo da castanha crua, somando 0,89\% de margem bruta $(\mathrm{Mb})$ e 3,17\% de markup de comercialização (tabela 04). Os cooperados obtiveram margens melhores, pois receberam $\mathrm{R} \$ 1,00$ a mais por quilo de castanha, totalizando 3,11\% de Mb e 11,11\% de Mk.

Os Custos unitários finais divergiram, pois os agroextrativistas cooperados precisam arcar com a taxa anual da COPABASE, elevando seus custos, ainda assim obtiveram um valor absoluto superior aos valores recebidos pelos não cooperados. Essa diferença reforça a importância de valorização do trabalho cooperativo, que contribui para o aumento das margens de comercialização dos agroextrativistas cooperados.

Tabela 04- Margem bruta (Mb) e markup (Mk), da cadeia produtiva do baru

\begin{tabular}{llllll}
\hline \multicolumn{1}{c}{ Categoria } & $\begin{array}{l}\mathbf{C p} \\
\mathbf{( R \mathbf { K g }} / \mathbf{K g})\end{array}$ & $\begin{array}{l}\text { Preço } \\
\text { venda }(\mathbf{R} \mathbf{\$})\end{array}$ & $\begin{array}{l}\mathbf{V a} *^{2} \\
\mathbf{( R \mathbf { } )}\end{array}$ & $\mathbf{M b}(\boldsymbol{\%})$ & $\mathbf{M k}(\boldsymbol{\%})$ \\
\hline Agroext. não cooperado & 14,50 & 14,96 & 0,4 & 0,89 & 3,17 \\
Agroext. cooperado & 15,09 & 16,11 & 0,89 & 1,98 & 6,79 \\
Cooperativa & - & 25,31 & 8,00 & 17,78 & 57,14 \\
Atacado & - & 40,27 & 13,00 & 28,89 & 59,09 \\
Varejo & - & 51,46 & 10,00 & 22,22 & 28,57 \\
Total & - & - & 31,00 & 68,89 & 221,43 \\
\hline${ }^{1}$ Cp: Custo de produção; ${ }^{2}$ Va: Valor absoluto não corrigido; Dados de Campo (2014).
\end{tabular}


Ao analisar os demais integrantes da cadeia produtiva, observou-se que, a cooperativa apropriou-se de $17,78 \%$, o atacadista $28,89 \%$ e o varejista $22,22 \%$ da margem bruta de comercialização. O Markup de comercialização totalizou 57,14\%, 59,09\% e 28,57\% respectivamente. No caso de comercialização dos agroextrativistas não cooperados a cooperativa aumenta suas margens para $20,00 \%$ de $\mathrm{Mb}$ e $69,23 \%$. Cabe ressaltar que a prioridade de aquisição é de agroextrativistas cooperados.

Diversos estudos que analisam as margens de comercialização $(\mathrm{Mb})$ de outros PFNMs foram realizados. Ao estudar o Cumaru (Dipteryx odorata Aubl.), Silva et al. (2010) estimaram uma margem de $20 \%$ para os extrativistas. Já Nogueira et al. (2006) calcularam uma margem bruta de 6,39\% para os coletores de cipó preto (Philodendron melanorrhizum Reitz) no litoral paranaense.

Para os percentuais dos produtos elaborados com óleo de copaíba (Copaifera multijuga Hayne) e andiroba (Carapa guianensis Aubl.) foram calculados 7,8\% e 7\% respectivamente (SANTOS e GUERRA, 2010). Já Pimentel et al. (2009) calcularam para o baru (Dipteryx alata VOGEL.) as margens de $25 \%$ e 26,73\% para agroextrativistas que entregam para duas entidades produtoras diferentes.

Os atacadistas apropriaram-se das maiores margens de comercialização, coincidindo com os resultados de Nogueira et al. (2006) e Santos e Guerra (2010). Apropriando-se de $28,89 \%$ da margem de comercialização, o varejo e a cooperativa somaram $22,22 \%$ e $17,78 \%$, respectivamente. Ao analisar o markup de comercialização, os maiores valores foram apropriados pelo atacado com o valor de 59,09\%, em relação ao valor de compra das entidades, e a cooperativa apropriou-se de $57,14 \%$ de $\mathrm{Mk}$.

Analisando comparativamente com os resultados obtidos por Pimentel et al. (2009), as margens das entidades estudadas foram de $70 \%$ e 56,6\%, significativamente maiores. Esses valores são devidos aos elevados custos do beneficiamento e torrefação do baru, que são executadas pelas entidades produtoras e comercializadas diretamente ao consumidor, diminuindo o número de integrantes do canal de comercialização, consequentemente agregando maiores porcentagens em suas margens. 
O menor valor do $\mathrm{Mk}$ foi auferido pelos agroextrativistas, resultado coincidente com outros estudos, mas deve-se considerar que todos os seus custos foram pagos. Todos os fatores de produção foram devidamente remunerados, como sua mão de obra, depreciações, materiais utilizados, etc. Portanto o preço pago pela cooperativa pode ser considerado justo.

Com exceção do agroextrativista, o markup dos demais componentes da cadeia estão relativamente equilibrados, principalmente ao analisar o markup de comercialização total, estimado em $221,43 \%$. Comparando com estudos similares, foi observado que é um valor baixo de Mk. Santos e Guerra (2010) calcularam um Mk de 900\% e 1.233\% para o óleo in natura e sabonete de óleo de copaíba, Silva et al. (2010) calcularam um Mk total de 500\% para o Cumaru e Nogueira et al. (2006) calcularam uma média de 770,09\% do Mk total para o cipó-preto.

Na mesorregião somente a castanha é comercializada, não ocorrendo o aproveitamento integral do fruto. Pode-se aproveitar o carvão dos frutos, que geralmente são descartados, farinha da polpa do baru, artesanatos, etc. $\mathrm{O}$ aproveitamento integral permite uma ampliação do comércio do baru, utilizando produtos e subprodutos do processo produtivo, permitindo a diversificação da produção.

Atividades que proporcionam maior agregação de valor aos produtos e subprodutos do baru devem ser incentivadas, objetivando a venda direta aos consumidores de pães, doces, sorvetes, etc., aumentando as margens de comercialização dos agroextrativistas.

Apesar dos esforços, as organizações da agricultura familiar não comercializaram as castanhas de baru utilizando o instrumento das compras governamentais, que incluem o Programa de Aquisição de Alimentos (PAA) e a Politica Nacional de Alimentação Escolar (PNAE). Essas possibilidades não devem ser descartadas, ampliando novas possibilidades de comercialização, a partir do fornecimento de produtos para alimentação escolar, órgãos públicos, etc.

Também não ocorreram subvenções diretas aos agroextrativistas, conforme preconiza a política de preços mínimos para produtos da sociobiodiversidade (PGPMBio). Esse problema é motivado por inexperiência dos agricultores e de suas organizações em acessar 
essa política pública, associado a baixa demanda das redes de ensino do municípo. Recentemente o Governo Federal, via Conab, definiu o custo de produção e o preço mínimo da atividade de extração da castanha, facilitando o acesso à PGPMBio. Entretanto, o mercado está remunerando acima do preço mínimo, não sendo necessária a subvenção.

A produção do baru, não deve ser abordada somente sobre a perspectiva do extrativismo. Estudos acerca do comportamento do baru em condições de plantio racional devem ser estimulados, pois a espécie possui um bom potencial silvicultural. Dessa forma, pode-se utilizar a espécie para compor quintais agroflorestais, sistemas agrosilvipastoris, enriquecimento de vegetações nativas, plantios homogêneos, etc. A domesticação não deve ser descartada, pois além de melhorar a produtividade, permite uma maior uniformização da produção, aumentando a qualidade do produto e diminuindo os custos de produção.

\section{CONCLUSÕES}

Somente um produto é comercializado pelos agroextrativistas, a atuação do sistema cooperativo é importante, proporcionando melhorias na divulgação e na organização do mercado. Outro ganho proporcionado pelo sistema cooperativo é o acesso a mercados, os quais não seriam possível os agroextrativistas acessarem isoladamente, principalmente o comércio via rede mundial de computadores, mercados de alta gastronomia, etc.

Para ampliar as margens de comercialização dos agroextrativistas é preciso diminuir custos, devendo os órgãos de pesquisa e inovação, assim como as organizações dos agroextrativistas, desenvolverem equipamentos mais eficientes na quebra do fruto.

Outra medida é o investimento em sistemas de armazenamento dos frutos e/ou das sementes, oferecendo as castanhas ao mercado nos períodos de entressafra. Essa medida também diminui os riscos associados à volatilidade da produção do baru de uma safra para outra.

A economia do baru possui a particularidade de ser uma atividade complementar na renda das famílias envolvidas, reforçando a importância da pluriatividade e multifuncionalidade da agricultura familiar. Essa caraterística proporciona uma maior sustentabilidade ao 
empreendimento da agricultura familiar, diminuindo a dependência de uma única atividade. Esta estratégia importante, pois a produção do baru é sazonal e cíclica, tornando os agroextrativistas menos vulneráveis nos anos de baixa produção.

Os atacadistas receberam as maiores margens de comercialização sobre o preço de compra, ao contrário dos outros estudos de referência, onde os varejistas auferiram maiores margens. Essa característica ocorre devido ao elevado custo de produção da castanha de baru, e as margens forem muito elevadas no varejo, pode-se inviabilizar o comércio, pois os consumidores buscarão produtos substitutos, devido ao preço elevado da castanha de baru. 


\section{REFERÊNCIAS BIBLIOGRÁFICAS}

ALMEIDA, L. S.; GAMA, J. R. V.; FERREIRA, M. S. G.; HOMMA, A. K. O.; MENEZES, J. E. A. Mercado de produto florestal não madeireiro em Santarém, Pará, Brasil. Revista Científica Juá FOPIESS, vol. 1, p. 9- 17, 2012.

ARAKAKI, A. A.; SCHEIDT, G. N.; PORTELLA, A. C.; ARRUDA, E. J.; COSTA, R. B. O baru (Dipteryx alata Vog.) como alternativa de sustentabilidade em área de fragmento florestal do Cerrado, no Mato Grosso do Sul. Revista Interações, Campo Grande, v. 10, n. 1, p. 31-39, 2009.

BANCO CENTRAL DO BRASIL, Calculadora do cidadão. Disponível em: https://www3.bcb.gov.br/CALCIDADAO/publico/exibirFormCorrecaoValores.do?method =exibirFormCorrecaoValores\&aba=1. Acesso em: 01/01/2016

BITTENCOURT, A. M. Aspectos econômicos do pinhão nas mesorregiões sudeste e centro-sul do estado do Paraná. Tese (Doutorado em Ciências Florestais) - Universidade Federal do Paraná, Curitiba, 170 p., 2012.

COPABASE, Cooperativa da Agricultura Familiar Sustentável com Base na Economia Solidaria. Plano de Negócios. Disponível em: 〈http://www.copabase.org/>. Acesso em: 18 set. 2013.

FERNANDES, D. C.; ALVES, A. M.; CASTRO G. S. F.; JORDÃO, A. A. Effects of Baru Almond and Brazil Nut Against Hyperlipidemia and Oxidative Stress In Vivo. Journal of Food Research. Toronto, v. 4, n. 4, p. 38-46, 2015.

KAR, S. P.; JACOBSON, M. G. NTFP income contribution to household economy and related socio-economic factors: Lessons from Bangladesh. Forest Policy and Economics, Pennsylvania, v. 14, p. 136-142, 2011.

MAGALHÃES, R. M. A cadeia produtiva da amêndoa do Baru (Dipteryx alata Vog.) no Cerrado: Uma análise da sustentabilidade de sua produção. Ciência Florestal, Santa Maria, v. 24, n. 3, p. 665-676, 2014.

MENDES, J. T. G.; PADILHA JUNIOR, J. B. Agronegócio: uma abordagem econômica. São Paulo, Pearson Prentice Hall, 2007.

BRASIL. Ministério do Desenvolvimento Agrário; Ministério do Meio Ambiente; Ministério de Desenvolvimento Social e Combate à Fome Plano Nacional para Promoção dos Produtos da Biodiversidade. Brasília, DF, 2009.

NOGUEIRA, A. S.; SANTOS, A. J.; BITTENCOURT, A. M.; BOLZON, D. R.; PAULA, F. S. Aspectos produtivos e econômicos da cadeia produtiva do cipó-preto no litoral paranaense. Floresta, Curitiba, v. 36, n. 3, 2006.

PIMENTEL, N. M.; DEL MENEZZI, C. H.; GONÇALEZ, J. Aproveitamento dos Produtos Florestais Não Madeireiros do Baru (Dipteryx alata Vog,). In: BENSUSAN, 
N. Unindo Sonhos: pesquisas ecossociais no cerrado. Brasília, Instituto Internacional de Educação no Brasil, p. 269-293. 2009.

RIBEIRO, J. F.; WALTER, B. M. T. As principais fitofisionomias do bioma cerrado. In: SANO, S. M.; ALMEIDA, S. P.; RIBEIRO, J. F. (Ed.). Cerrado: ecologia e flora, DF: Embrapa Informação Tecnológica, Brasília, 2008. p. 151-212.

SANTOS, A. J. dos; GUERRA, F. G. P. de Q. Aspectos Econômicos da Cadeia Produtiva dos Óleos de Andiroba (Carapa Guianensis Aubl.) e Copaíba (Copaifera Multijuga Hayne) na Floresta Nacional Do Tapajós - Pará. Floresta, Curitiba, v. 40, n. 1, p. 23-28, 2010.

SILVA, T. M. da.; JARDIM, C. S.; SILVA, M. S.; SHANLEY P. O mercado de amêndoas de Dipteryx odorada (cumaru) no estado do Pará. Floresta, Curitiba, v. 40, n. 3, p. 603 $614,2010$.

TAPIA, E. D. C.T.; CHILPA, R. R. Productos forestales no maderables em México: Aspectos económicos para el desarrollo sustentable. Madera y Bosques, Coyoacán, v.14, p. 95-112, 2008. 
ANEXOS 


\section{ANEXO I - Questionário Análise econômica das famílias agroextrativistas}

Coordenadas geográficas:

Data:

Elo da cadeia:

\section{CARACTERÍSTICAS SOCIAIS E ECONÔMICAS DAS FAMÍLIAS EXTRATIVISTAS}

1.1 Caracterização da família

1. Nome

2. Local de nascimento

3. Nome da propriedade/comunidade

4. Tempo que mora na comunidade

5. Profissão

6. Número de membros na família, sexo e idade? Parentesco?

1.2 Possui propriedade rural? Qual o uso e ocupação do solo?

1.3 Recebe Assistência técnica?

1.4 É cooperado ou associado a alguma organização? Acha importante participar?

1.5 Ocorreram melhorias no mercado do baru depois da atuação de cooperativas?

\section{CARACTERÍSTICAS GERAIS DA ATIVIDADE}

2.1 Quantos atua na atividade do baru? Porque?

2.2 Coleta :

2.2.1 Pratica a coleta? ( ) Sim ( ) Não Quem coleta?

2.2.2 Adquire os frutos? ( ) Compra de coletores ( ) Contrata coletores

2.2.3 Onde? ( ) Terra própria ( ) Terras de terceiros ( ) Outros:

2.2.4 Tem dificuldades de acesso? ( ) Sim ( ) Não

2.2.5 Quando coletado em terras de terceiros o fruto é: ( ) Doado ( ) Produção repartida

2.2.6 Como coleta? ( ) coleta no chão ( ) derruba os frutos ( ) Observação:

2.2.7 Em que vegetação? ( ) Florestas ( ) Cerrado ( ) Pastagens ( ) Outros:

2.2.8 Coletam todos os frutos que encontram? ( ) Sim ( ) Não

2.2.9 Ocorre contratação de mão de obra de terceiros? ( ) Sim ( ) Não

Tempo de contratação:

Valor da remuneração:

2.2.10 Quantos sacos por dia são coletados?

2.2.11 Quantos dias por ano ocorrem a coleta?

2.2.13 Qual a produção média de uma árvore jovem?( ) Safra: ( ) Entressafra

2.2.14 Qual a produção média de uma árvore adulta? ( ) Safra: Entressafra 
2.2.15 Quais materiais utilizados na coleta? Quais custos envolvidos?

2.216 Existem rotas de coleta organizada? ( ) Sim ( ) Não

Rotas de coleta

\begin{tabular}{|l|l|l|l|l|l|l|}
\hline Local & Área & Locomoção & Distância & árvores & Sacos/árvores & Custos \\
\hline & & & & & & \\
\hline
\end{tabular}

\section{3 $\quad$ Transporte}

2.3.1 Como é realizado o transporte do material?

( ) Carrinho de mão ( ) carroça ( ) cavalo ( ) a pé ( ) carro

2.3.2 Quantos quilos são transportados por dia? Quantos dias de coleta por semana? Quantas semanas?

2.3.3 Alugam e/ou contrata transporte? Valor?

2.3.4 Outros custos:

\subsection{Processamento}

2.4.1 Qual o processamento realizado? ( ) Quebra ( ) Torrefação ( ) Envasamento

2.4.2 Existe equipamento? Qual? Alugado?

2.4.3 Existem perdas? Quanto?

2.4.4 Seleciona as sementes? Qual critério?

2.4.5 Qual rendimento por pessoa/dia? Quantas horas?

2.4.6 Contrata? Quanto tempo? Custos?

\subsubsection{Separacão e Selecão}

2.4.7.1 Essa atividade é realizada junto com a quebra do fruto?

2.4.7.2 Qual o tempo necessário para separar a castanha do fruto?

2.4.7.3 Qual o tempo necessário para selecionar as castanhas?

2.4.7.4 Quem realiza essa atividade?

\subsection{Armazenamento}

2.7.1 Armazena os frutos: ( ) Sim ( ) Não

2.7.2 Onde armazena os frutos? Local: ( ) galpão próprio ( ) galpão de terceiros ( ) paiol ( ) Outros:

2.7.3 Quanto tempo de armazenamento?

2.7.3 Quem armazena? 
2.7.4 Quais os custos?

\subsection{Torrefacão}

2.6.1 Torra o baru? ( ) Sim ( ) Não 3.8.2 Quem torra?

2.6.2 Onde torra?

2.6.3 Tempo gasto nessa etapa? Quantidade?

2.6.4 Quem torra?

2.6.5 Custos?

\subsection{Envaze}

2.9.1 Onde são envazados as castanhas do baru? ( ) Garrafa pet reutilizada ( ) sacos aniagem ( ) vasilhames

2.9.2 Quem envaza?

2.9.3 Quais os custos?

\section{COMERCIALIZAÇÃO}

3.1 Produtos vendidos? ( ) fruto ( ) castanha crua ( ) castanha torrada ( ) outro:

3.2Para quem? ( ) varejo ( ) atacado ( ) cooperativa ( ) intermediário ( ) feiras

3.3 Armazenam para vender na entre safra? ( ) Sim ( ) Não

3.4 Qual o preço de Venda? E nos anos anteriores?
Produto:
Ano:
( ) Safra:
( ) Entressafra
Produto:
Ano:
( ) Safra:
( ) Entressafra

3.5 Qual o preço de compra? E nos anos anteriores?
Ano:
( ) Safra:
( ) Entressafra
Ano:
( ) Safra:
( ) Entressafra

3.6 Têm preços diferenciados no atacado e varejo?

3.7 Qual a quantidade comercializada?
Ano:
( ) Quantidade:
Ano:
( ) Quantidade:

3.8 Principais dificuldades?

3.9 Quem vende?

3.10 Custos?

\section{RECEITAS}

\begin{tabular}{|l|l|l|l|l|l|l|}
\hline Atividades & Unid & Qdade & Valor (R\$) & Renda & Observação & \% Renda \\
\hline Agricultura & & & & & & \\
\hline Pecuária corte & & & & & & \\
\hline Pecuária leite & & & & & & \\
\hline Avicultura & & & & & & \\
\hline
\end{tabular}




\begin{tabular}{|l|l|l|l|l|l|l|} 
Suinocultura & & & & & & \\
\hline Baru & & & & & & \\
\hline Outros frutos & & & & & & \\
\hline Aluguel de Animais & & & & & & \\
\hline Piscicultura & & & & & & \\
\hline Aposentadoria & & & & & & \\
\hline $\begin{array}{l}\text { Emprego } \\
\text { assalariado }\end{array}$ & & & & & & \\
\hline $\begin{array}{l}\text { Diárias de prestação } \\
\text { de serviços }\end{array}$ & & & & & & \\
\hline Bolsa família & & & & & & \\
\hline Observação & & & & & & \\
\hline \multicolumn{1}{|c|}{ TOTAL } & & & & & & \\
\hline
\end{tabular}

OBS:

4.1 Qual a principal fonte de renda da família?

\section{DEMAIS CUSTOS}

Telefonemas?

Custos com taxas, impostos, cadastros?

Serviços administrativos?

Aluguel de maquinários?

\section{INFORMAÇÕES GERAIS}

É possível sobreviver somente da renda do baru?

Se você se esforçasse em coletar mais baru, para aumentar sua produção, você conseguiria? Quanto acha que conseguiria coletar e quebrar?

Qual a pior atividade do mercado do baru?

Estaria disposto a somente comercializar os frutos do baru? Ou prefere comercializar a castanha?

Se você tivesse a oportunidade de um emprego assalariado, manteria a atividade do baru?

Aumentou a preservação do baru?

Estaria disposto a investir recursos em plantio de baru?

Foi orientado sobre técnicas de extrativismo sustentável?

O que fazer para melhorar o mercado do baru?

Conhece mais algum agroextrativista?

Observações gerais 
Identificação:

Contato:

1. Como você conheceu o Baru?

a) Pela televisão

b) Por jornais escritos e/ou revistas

c) Mora em região produtora

d) Comprou no comércio

e) Outro. Quais?

2. Porque vocês vendem o baru?

a) Preservação do cerrado

b) Alta demanda pela castanha

c) Estímulos através de políticas públicas

d) Alto valor nutritivo, bom para saúde

e) Outros.

3. Quais as formas de compra do baru?
a) ( ) Frutos
b) ( ) Castanha Crua
c) ( ) Castanha Torrada
d) ( ) Óleo
e) Outras. Quais?

4. Desde que ano que vocês vendem o baru?

a) Antes de 2007 (Qual ano?

b) $\quad 2008$

c) $\quad 2009$

d) 2010

e) Depois de 2011 (Qual ano?

5. Qual a quantidade de baru vendido mensalmente?
a) Menos que $100 \mathrm{~kg}$
b) Entre 100 a $300 \mathrm{~kg}$
c) Entre 300 a $700 \mathrm{~kg}$
d) Entre 700 a $1500 \mathrm{~kg}$
e) Maior que $1500 \mathrm{~kg}$

6. Qual o preço de compra da castanha? Tem diferença entre épocas do ano? ( ) Sim ( ) Não

Safra: 2013: 2014:

Entressafra: 2013: 2014:

7. De quem adquire?
a) Agroextrativistas
b) Atacadistas
c) Cooperativas
d) Intermediários/atravessadores 
e) Produção própria

8. De qual região é adquirido o baru comercializado?
a) Arinos/MG
b) Alto Paraíso/GO
c) Jussara/GO
d) Pirenópolis/GO
e) Outros:

9. Para quem vende?
a) Atacadistas
b) Consumidor final
c) Varejistas
d) Outros:

10. Quais as formas de venda do baru?
a) ( ) Farinha
b) ( ) Castanha Crua
c) ( ) Castanha Torrada
d) ( ) Óleo
e) Outras. Quais?

11. Qual o preço de venda da castanha? Tem diferença entre épocas do ano?

( ) $\operatorname{Sim}$ ( ) Não

Safra: 2013:

Entressafra: 2013: $\quad$ 2014:

12. Quais os maiores problemas para a comercialização do baru?
a) Falta divulgação
b) Mercado informal
c) Faltam produtos (sazonalidade)
d) Falta organização do setor
e) Falta de qualidade
f) Outros

13. Qual o perfil do consumidor?
a) Procura de alimentos saudáveis
b) Procura por produtos ecossociais
c) Preservação do meio ambiente
d) Outros

14. Qual etapa produtiva vocês exercem:
a) Coleta
b) Quebra
c) Torrefação
d) Envasamento
e) Etiquetagem 
ANEXO III

Série histórica mensal do IGP-DI (FGV) do horizonte de planejamento adotado

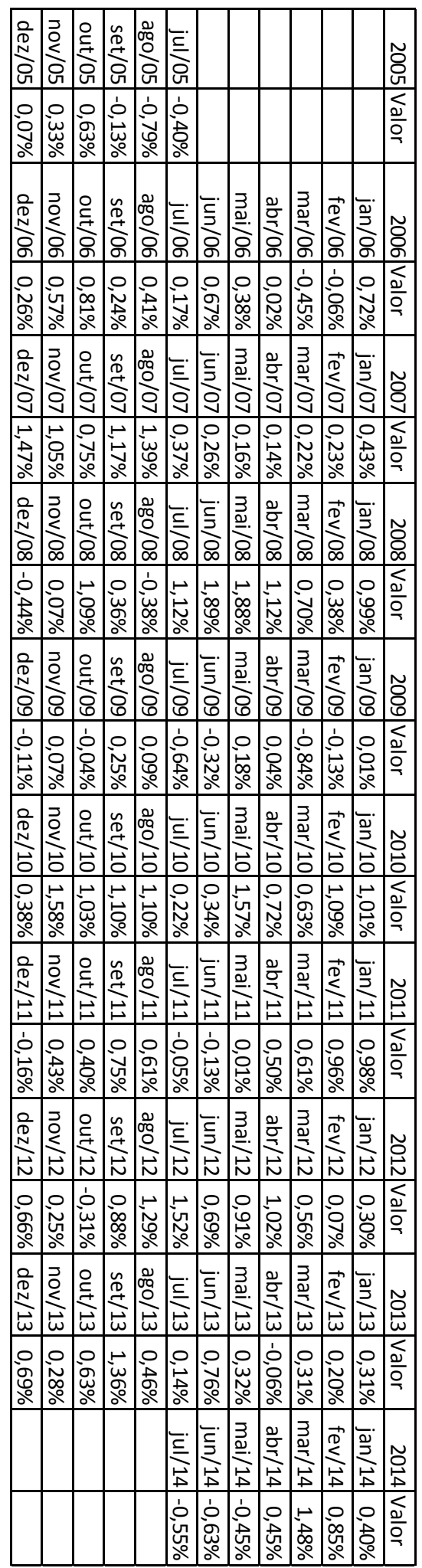




\section{ANEXO IV}

Série histórica dos custos variáveis dos agroextrativistas médios

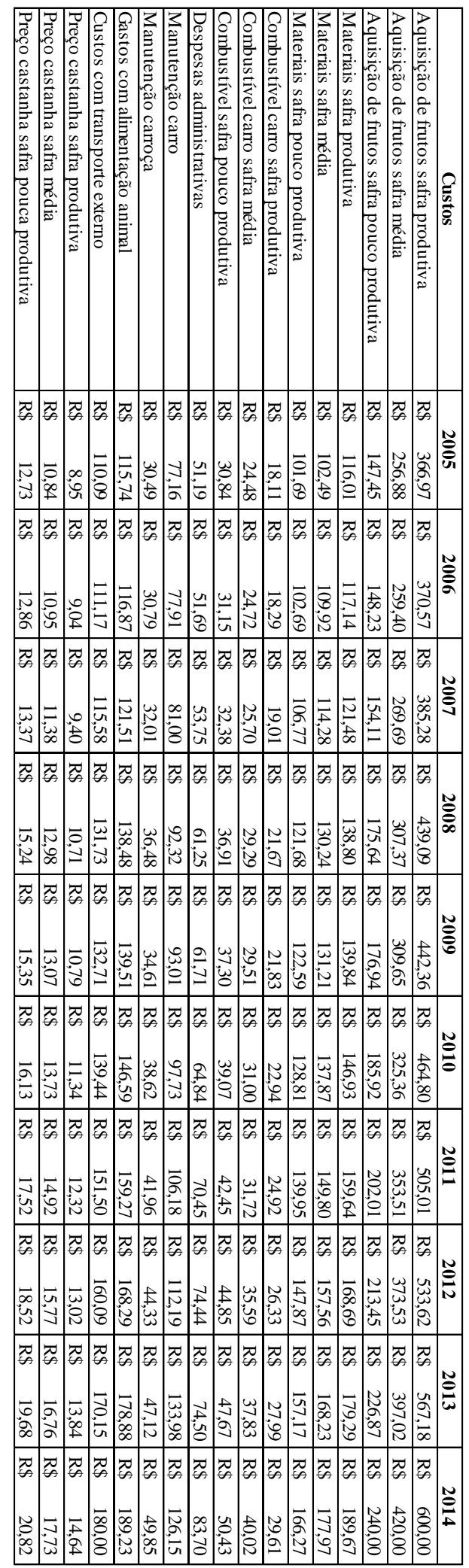




\section{ANEXO V}

Série histórica dos custos variáveis dos Agroextrativistas mais produtivos

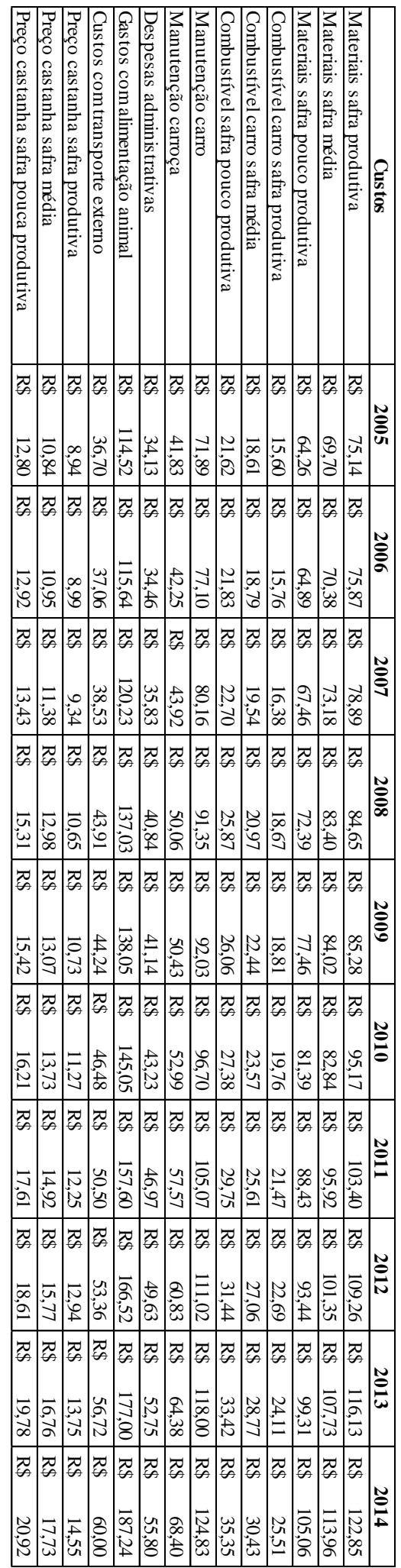




\section{ANEXO VI}

Série histórica dos custos variáveis do Coletivo de Agroextrativistas

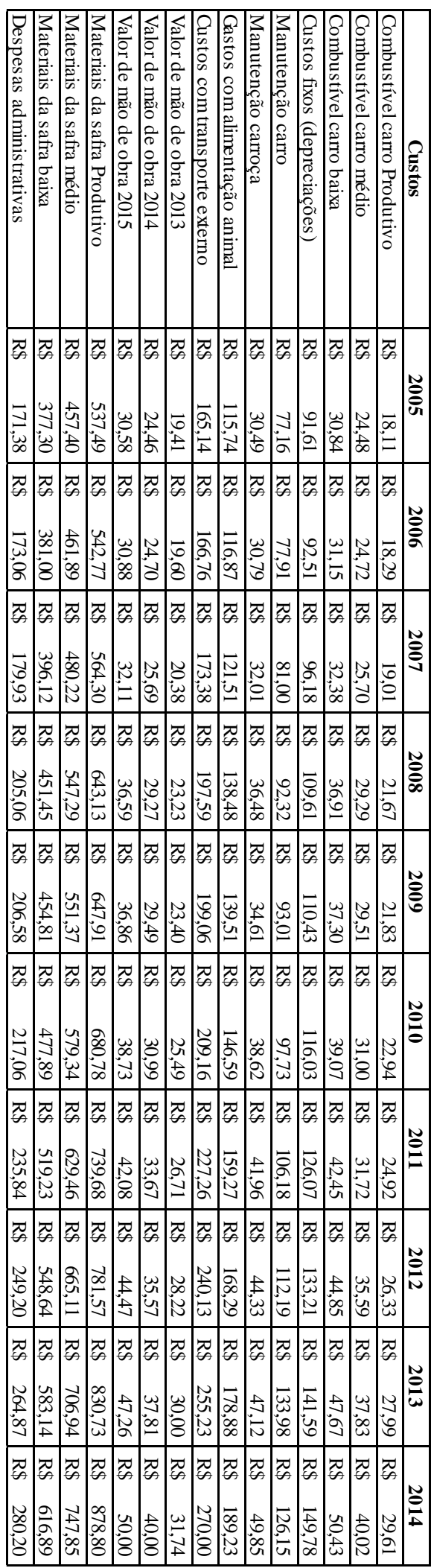


ANEXO VII

Série histórica dos valores de mão de obra, custos fixos e investimentos

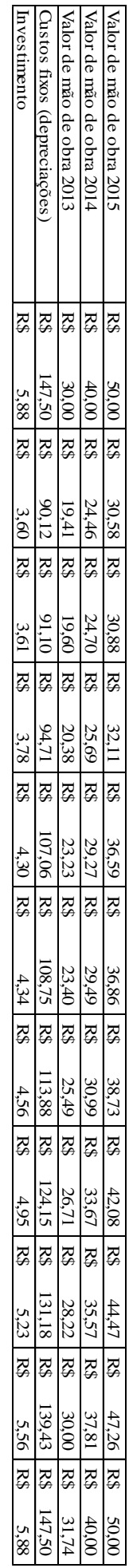

